\title{
Medical Application of Calcium Orthophosphate Bioceramics
}

\author{
Sergey V. Dorozhkin \\ Researcher, Kudrinskaja sq. 1-155, Moscow 123242, Russia. \\ Tel: 7-499-255-4460, E-mail: sedorozhkin@yandex.ru
}

doi:10.5618/bio.2011.v1.n1.1 || Received: Jan. 13, 2011, Accepted: Jan. 26, 2011, Available online: Feb. 21, 2011

\begin{abstract}
In the late 1960's, a strong interest was raised in biomedical applications of ceramic materials (named bioceramics a little bit later). Bioceramics was initially used as reasonable alternatives to metals in order to increase their biocompatibility. However, within a short period, it has grown into a diverse class of biomaterials, presently including three essential types: relatively bioinert, bioactive (or surface reactive) and bioresorbable bioceramics. This review is limited to bioceramics prepared from calcium orthophosphates only, which belong to the categories of bioactive and bioresorbable compounds. There have been a number of important advances in this field during the past 30 - 40 years. The research was shifted from an initial study on the develop-ment of bioinert bioceramics towards bioactive and bioresorbable bioceramics, and these different types of calcium orthophosphate bioceramics can be tuned through the structural and compositional control. At the turn of the millennium, a new concept of calcium orthophosphate bioceramics has been developed to promote a regeneration of bones. Current biomedical applications of calcium orthophosphate bioceramics include artificial replacements for hips, knees, teeth, tendons and ligaments, as well as repair for periodontal disease, maxillofacial reconstruction, augmenttation and stabilization of the jawbone, spinal fusion and bone fillers after tumor surgery. Potential future applications of calcium orthophosphate bioceramics are demonstrated in drug delivery systems, effective carriers of growth factors, bioactive peptides and/or various types of cells for tissue engineering purposes.
\end{abstract}

Keywords: Calcium Orthophosphates; Hydroxyapatite; Tricalcium Phosphate; Bioceramics; Biomaterials; Grafts; Biomedical Applications; Tissue Engineering.
Review's outline

1. Introduction

2. General knowledge on biomaterials and bioceramics

3. Bioceramics of calcium orthophosphates

3.1. History

3.2. Chemical composition and preparation

3.3. Forming and shaping

3.4. Sintering and firing

4. The major properties

4.1. Mechanical properties

4.2. Electrical properties

4.3. Possible transparency

4.4. Porosity

5. Biomedical applications

5.1. Cements and concretes

5.2. Coatings

5.3. Functionally graded bioceramics

6. Biological properties and in vivo behavior

6.1. Interaction with surrounding tissues and the host responses

6.2. Osteoinduction

6.3. Biodegradation

6.4. Bioactivity

6.5. Cellular response

7. Calcium orthophosphate bioceramics in tissue engineering

7.1. Tissue engineering

7.2. Scaffolds and their properties

7.3. Bioceramic scaffolds from calcium orthophosphates

7.4. A clinical experience

8. Conclusions and outlook 


\section{Introduction}

Medical application is one of the most exciting and rewarding research areas of the materials science. Examples from our daily life are sutures, catheters, heart valves, pacemakers, breast implants, fracture fixation plates, nails and screws in orthopedics, dental filling materials, orthodontic wires, as well as total joint replacement prostheses. During the past decades, both an ageing population and a democratization of high-risk sports have led to a surge of bone-related diseases and bone fractures, which must be treated through implants. In order to be accepted by the living body, all implantable items must be prepared from a special class of materials, called biomedical materials or biomaterials in short.

All solid materials are generally categorized as four major groups: metals, polymers ceramics and composites thereof. Similarly, all biomaterials are also divided into the same major types: biometals, biopolymers, bioceramics and biocomposites. All of them play very important roles in both replacement and regeneration of the human tissues. Due to a great number of publications in biomaterials, this review is limited to bioceramics, particularly calcium orthophosphate-based bioceramics only. In general the modern bioceramics comprise various polycrystalline materials, glasses, glass-ceramics, as well as ceramicfilled bioactive [1] composites. All of them might be manufactured in both porous and dense forms in bulk, as well as in the forms of powders, granules and/or coatings. An expansion of bioceramics to the health care has been characterized by a significant increasing in the number of publications and patents in this field and an

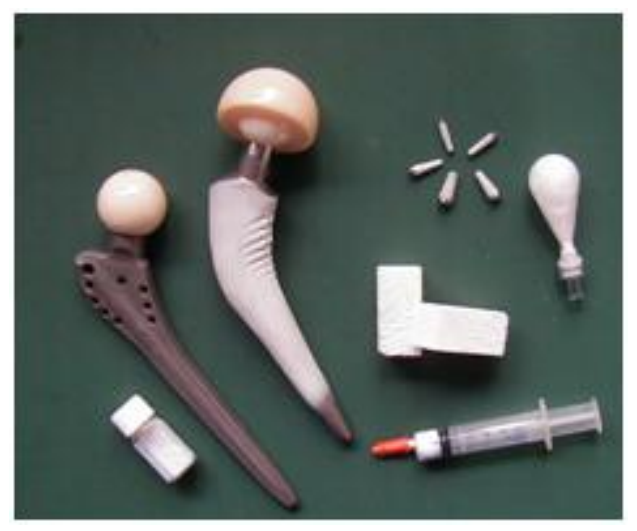

Fig. 1. Several examples of the commercial calcium orthophosphatebased bioceramics. ever-increasing number of major international conferences and themed meetings [2-6].

Calcium orthophosphate-based bioceramics and biomaterials are found in a variety of different applications throughout the body, covering all areas of the skeleton: dental implants, percutaneous devices and use in periodontal treatment, healing of bone defects, fracture treatment, total joint replacement (bone augmentation), orthopedics, cranio-maxillofacial reconstruction, otolaryngology, ophthalmology and spinal surgery [3-7]. Fig. 1 shows some randomly chosen samples of the commercially available calcium orthophosphate bioceramics for bone graft applications. Regardless of their diverse applications in medical, bioceramics are amazingly manufactured from the compounds with elements that just form a small set of the Periodic Table. These compounds include alumina, zirconia, magnesia, carbon, silica-contained and calcium-contained compounds, as well as some other chemicals [4].

In this review, the focus has been placed upon applications of calcium orthophosphate bioceramics as medical implants to repair and reconstruct the damaged or diseased hard tissues (usually, those of the musculoskeletal system, such as bones or teeth) of the body and to describe some of the major developments in this field during the past $\sim 40$ years. To narrow the subject further, with a few important exceptions, bioceramics prepared from undoped and un-substituted calcium orthophosphates have been considered and discussed only. Calcium orthophosphate bioceramics prepared from the biological resources, such as bones, teeth, corals, etc. [8-38] is not considered here.

\section{General knowledge on biomaterials and bioceramics}

A number of definitions have been developed for the term "biomaterials". Until recently, there has been a consensus developed by the experts in this field: "biomaterials are defined as synthetic or natural materials to be used to replace parts of a living system or to function in intimate contact with living tissues" [39]. After that, a more advanced definition has been introduced in September 2009: "A biomaterial is a substance that has been engineered to take a form which, alone or as part of a complex system, is used to direct, by control of interactions with components of living systems, the course of any therapeutic or diagnostic procedure, in human or veterinary medicine" [40]. These alterations in the definitions reflect a shift in conceptual ideas on biomaterials and the expectations of their biological performance, which both have changed in time [41].The biomaterials discipline is founded on 
the knowledge of the synergistic interface of material science, biology, chemistry, medicine and mechanical science and requires the input of comprehension from all these areas so that implanted biomaterials perform adequately in a living body and interrupt normal body functions as little as possible [42]. Among all of these areas, the knowledge in chemistry, material science and engineering is essential as biomaterials mainly deal with material synthesis and processing. To achieve good clinical applications, which are the main purposes of biomaterials, biomedical sciences become the key part of the research. These include cell and molecular biology, anatomy and animal and human physiology. Prior to its clinical application, any potential biomaterial must also pass all regulatory requirements [43]. The final aim of biomaterials is to achieve the correct biological interaction of the implanted biomaterials with living tissues of a host. These goals have to be achieved through several stages: material synthesis, design and manufacturing of prostheses, followed by various types of tests.

The major character of biomaterials different from other classes of materials is their ability to remain in a biological environment without damaging the surroundings and without being damaged in that process. Biomaterials are mainly utilized in form of implants (sutures, bone plates, joint replacements, ligaments, vascular grafts, etc.) and medical devices (pacemakers, biosensors, artificial hearts, blood tubes, etc.). These forms of biomaterials are widely used in different applications throughout the body [5, 6, 45] to replace and/or restore the function of traumatized or degenerated tissues or organs, to assist in healing, to improve function, to correct abnormalities, and thus to improve the quality of life of the patients [44]. In conclusion, biomaterials are solely associated with the health care domain and must have an interface with tissues or tissue components. Any artificial materials that simply are in contact with skin, such as hearing aids and wearable artificial limbs, are not included in the definition of biomaterials since the skin acts as a protective barrier between the body and the external world.

Biomaterials must be distinguished from biological materials because the former are the materials that are accepted by living tissues and, therefore, they might be used for tissue replacements, while the latter are the materials being produced by various biological systems (wood, cotton, bones, chitin, etc.) [46]. In addition, there are another concept biomimetic materials, which are not made by living organisms but have the composition, structure and properties similar to those of biological materials. This review is about bioceramics (or bio- medical ceramics) which might be defined as biomaterials of the ceramic [47] origin. Bioceramics can have structural functions as joint or tissue replacements, be used as coatings to improve the biocompatibility [48] of metal implants, as well as function as resorbable lattices, providing temporary structures and frameworks that are dissolved and/or replaced as the body rebuilds the damaged tissues [49-55]. Some types of bioceramics even feature a drug-delivery capability $[56,57]$.

Bioceramics is needed to alleviate pain and restore functions to diseased or damaged calcified tissues (bones and teeth) of the body. Bone is especially vulnerable to fracture in older people due to a loss of density and strength with age. This effect is especially severe in women due to the hormonal changes associated with menopause. A great challenge facing its medical application is to replace old, deteriorating bone with a material that can function the remaining years of the patient's life and, ideally, be replaced by a new mature bone without transient loss of mechanical support [2]. Surface reactivity is one of the common characteristics of bioceramics. It contributes to their bone bonding ability and their enhancing effect on bone tissue formation. During implantation, various interactions occur at the material/tissue interfaces that lead to time-dependent changes in the surface characteristics of the implanted bioceramics and the surrounding tissues [58]. Because the average life span of humans is now $80+$ years and the major need for spare parts begins at about 60 years of age, the implanted non-resorbable bioceramics need to last, at least, for $20+$ years. This demanding requirement of survivability is under conditions of use that are especially harsh to implanted materials: corrosive saline solutions at $37{ }^{\circ} \mathrm{C}$ under variable, multiaxial and cyclical mechanical loads. The excellent performance of the specially designed bioceramics that have survived these clinical conditions represents one of the most remarkable accomplishments of research, development, production and quality assurance during the past century [51].

\section{Bioceramics of calcium orthophosphates}

3.1. History Man's attempts to repair the human body with the use of implant materials were recorded in the early medical writings of the Hindu, Egyptian and Greek civilizations. The earliest successful implants were in the skeletal system. In early times, a selection of the materials was based on their availability and an ingenuity of the individual making and applying the prosthetic [59]. Some example biomaterials seem in museum exhibits from archaeological findings are animal or human (from corpses) bones and teeth, shells, 
corals, ivory (elephant tusk), wood, as well as some metals (gold or silver). For instance, the Etruscans learned to substitute missing teeth with bridges made from artificial teeth carved from the bones of oxen, while in ancient Phoenicia loose teeth were bound together with gold wires for tying artificial ones to neighboring teeth. In the $17^{\text {th }}$ century, a piece of dog skull was successfully transplanted into the damaged skull of a Dutch duke. The Chinese recorded the first use of dental amalgam to repair decayed teeth in the year 659 AD, while pre-Columbian civilizations used gold sheets to heal cranial cavities following trepanation [60]. Furthermore, in 1970, Amadeo Bobbio discovered Mayan skulls, some of them more than $\sim 4000$ years old, in which missing teeth had been replaced by nacre substitutes [61]. Unfortunately, due to the practice of cremation in many societies, little is known about prehistoric materials used to replace bone lost to accident or disease.

Plaster of Paris was the first widely tested artificial bioceramics in history. In the past many implantations failed due to infections, and furthermore the infections tended to be exacerbated in the presence of implants, since they provided a region inaccessible to the body's immunologically competent cells. The use of biomaterials did not become practical until the advent of an aseptic surgical technique developed by Dr. J. Lister in the 1860's. Furthermore, there was a lack of knowledge about a toxicity of the selected materials. In this frame, application of calcium orthophosphates appears to be logical due to their similarity with the mineral phases of bones and teeth [62-66]. Calcium orthophosphates (Table 1) are not toxic and do not cause cell death in the surrounding tissues. According to available literature, the first attempt to use them (it was TCP) as an artificial material to repair surgically created defects in rabbits was performed in 1920 [67]. Although this may be the first scientific study on use of a calcium orthophosphate for bone defects repair, it remains unclear whether the calcium orthophosphate was a precipitated or a ceramic material and whether it was in a powder or granular form. The second clinical report was only published 30 years later [68]. More than twenty years afterwards, the first dental application of a calcium orthophosphate (erroneously described as TCP) in surgically created periodontal defects [69] and the use of dense HA cylinders for immediate tooth root replacement [70] were reported. According to the available databases, the first paper with the term "bioceramics" in the abstract was published in 1971 [71], while with that in the title were published in 1972 $[72,73]$. However, application of the ceramic materials as prostheses had been known prior to that time [74-77]. Further historical details might be found in literature $[78,79]$. The first international symposium on bioceramics was held in Kyoto, Japan on April 26, 1988.

Commercialization of the dental and surgical applications of calcium orthophosphate (mainly, HA) bioceramics occurred in the 1980's, largely due to the pioneering efforts by Jarcho [80-83] in the USA, de Groot [84-86] in Europe and Aoki [87-103] in Japan. Shortly afterwards HA has become a bioceramic of reference in the field of calcium orthophosphates for biomedical applications. Preparation and biomedical applications of apatites derived from sea corals (coralline HA) [91-93] and bovine bone [94] have been reported at the same time [95]. 
Sergey V. Dorozhkin / BIO 2011, 1, 1-51 @CCAAS

Table 1. Existing calcium orthophosphates and their major properties [143, 144].

\begin{tabular}{|c|c|c|c|c|c|}
\hline $\begin{array}{c}\mathrm{Ca} / \mathrm{P} \\
\text { molar } \\
\text { ratio }\end{array}$ & Compound & Formula & $\begin{array}{c}\text { Solubility at } \\
25^{\circ} \mathrm{C},-\log \left(\mathbf{K}_{\mathrm{s}}\right)\end{array}$ & $\begin{array}{r}\text { Solubility at } \\
25^{\circ} \mathrm{C}, \mathrm{g} / \mathrm{L}\end{array}$ & $\begin{array}{l}\text { pH stability range in } \\
\text { aqueous solutions at } 25^{\circ} \mathrm{C}\end{array}$ \\
\hline 0.5 & $\begin{array}{l}\text { Monocalcium phosphate monohydrate } \\
\text { (MCPM) }\end{array}$ & $\mathrm{Ca}\left(\mathrm{H}_{2} \mathrm{PO}_{4}\right)_{2} \cdot \mathrm{H}_{2} \mathrm{O}$ & 1.14 & $\sim 18$ & $0.0-2.0$ \\
\hline 0.5 & $\begin{array}{l}\text { Monocalcium phosphate anhydrous } \\
\text { (MCPA or MCP) }\end{array}$ & $\mathrm{Ca}\left(\mathrm{H}_{2} \mathrm{PO}_{4}\right)_{2}$ & 1.14 & $\sim 17$ & [c] \\
\hline 1.0 & $\begin{array}{l}\text { Dicalcium phosphate dihydrate (DCPD), } \\
\text { mineral brushite }\end{array}$ & $\mathrm{CaHPO}_{4} \cdot 2 \mathrm{H}_{2} \mathrm{O}$ & 6.59 & $\sim 0.088$ & $2.0-6.0$ \\
\hline 1.0 & $\begin{array}{c}\text { Dicalcium phosphate anhydrous (DCPA or } \\
\text { DCP), mineral monetite }\end{array}$ & $\mathrm{CaHPO}_{4}$ & 6.90 & $\sim 0.048$ & [c] \\
\hline 1.33 & Octacalcium phosphate (OCP) & $\mathrm{Ca}_{8}\left(\mathrm{HPO}_{4}\right)_{2}\left(\mathrm{PO}_{4}\right)_{4} \cdot 5 \mathrm{H}_{2} \mathrm{O}$ & 96.6 & $\sim 0.0081$ & $5.5-7.0$ \\
\hline 1.5 & $\alpha$-Tricalcium phosphate ( $\alpha$-TCP) & $\alpha-\mathrm{Ca}_{3}\left(\mathrm{PO}_{4}\right)_{2}$ & 25.5 & $\sim 0.0025$ & [a] \\
\hline 1.5 & $\beta$-Tricalcium phosphate $(\beta$-TCP) & $\beta-\mathrm{Ca}_{3}\left(\mathrm{PO}_{4}\right)_{2}$ & 28.9 & $\sim 0.0005$ & [a] \\
\hline $1.2-2.2$ & Amorphous calcium phosphates (ACP) & $\begin{array}{c}\mathrm{Ca}_{x} \mathrm{H}_{y}\left(\mathrm{PO}_{4}\right)_{z} \cdot n \mathrm{H}_{2} \mathrm{O}, n=3-4.5 \\
15-20 \% \mathrm{H}_{2} \mathrm{O}\end{array}$ & {$[\mathrm{b}]$} & {$[\mathrm{b}]$} & $\sim 5-12^{[\mathrm{d}]}$ \\
\hline $1.5-1.67$ & $\begin{array}{c}\text { Calcium-deficient hydroxyapatite (CDHA } \\
\text { or Ca-def HA) }{ }^{[\mathrm{e}]}\end{array}$ & $\begin{array}{c}\mathrm{Ca}_{10-x}\left(\mathrm{HPO}_{4}\right)_{x}\left(\mathrm{PO}_{4}\right)_{6-x}(\mathrm{OH})_{2-x} \\
(0<x<1)\end{array}$ & $\sim 85$ & $\sim 0.0094$ & $6.5-9.5$ \\
\hline 1.67 & Hydroxyapatite (HA, HAp or OHAp) & $\mathrm{Ca}_{10}\left(\mathrm{PO}_{4}\right)_{6}(\mathrm{OH})_{2}$ & 116.8 & $\sim 0.0003$ & $9.5-12$ \\
\hline 1.67 & Fluorapatite (FA or FAp) & $\mathrm{Ca}_{10}\left(\mathrm{PO}_{4}\right)_{6} \mathrm{~F}_{2}$ & 120.0 & $\sim 0.0002$ & $7-12$ \\
\hline 1.67 & Oxyapatite (OA, OAp or OXA) $)^{[\mathrm{f}]}$ & $\mathrm{Ca}_{10}\left(\mathrm{PO}_{4}\right)_{6} \mathrm{O}$ & $\sim 69$ & $\sim 0.087$ & {$[\mathrm{a}]$} \\
\hline 2.0 & $\begin{array}{c}\text { Tetracalcium phosphate (TTCP or TetCP), } \\
\text { mineral hilgenstockite }\end{array}$ & $\mathrm{Ca}_{4}\left(\mathrm{PO}_{4}\right)_{2} \mathrm{O}$ & $38-44$ & $\sim 0.0007$ & [a] \\
\hline
\end{tabular}

${ }^{[\mathrm{a}]}$ These compounds cannot be precipitated from aqueous solutions.

${ }^{[\mathrm{b}]}$ Cannot be measured precisely. However, the following values were found: $25.7 \pm 0.1(\mathrm{pH}=7.40), 29.9 \pm 0.1(\mathrm{pH}=6.00), 32.7 \pm 0.1(\mathrm{pH}=5.28)$. The comparative extent of dissolution in acidic buffer is: $\mathrm{ACP}>>\alpha-\mathrm{TCP}>>\beta-\mathrm{TCP}>\mathrm{CDHA}>>\mathrm{HA}>\mathrm{FA}$.

${ }^{[\mathrm{c}]}$ Stable at temperatures above $100^{\circ} \mathrm{C}$.

${ }^{\text {[d] }}$ Always metastable.

${ }^{[\mathrm{e}]}$ Occasionally, it is called "precipitated HA (PHA)".

${ }^{[\mathrm{f}]}$ Existence of OA remains questionable. 


\subsection{Chemical composition and preparation}

Although calcium orthophosphate bioceramics currently can be prepared from various sources [96-109, 787], up to now, all attempts to synthesize bone replacement materials for clinical applications featuring the physiological tolerance, biocompatibility and a longterm stability have had only a relative success. This shows the superiority and a complexity of the natural structures [110].

Calcium orthophosphate bioceramics should be characterized from many aspects such as the chemical composition (stoichiometry and purity), homogeneity, phase distribution, morphology, grain sizes and shape, grain boundaries, crystallite size, crystallinity, pores, cracks, surface, etc. From the chemical composition point of view, the vast majority of calcium orthophosphate bioceramics is based on HA, $\beta$-TCP, $\alpha$ TCP and/or biphasic calcium phosphate (BCP). BCP is an intimate mixture of either $\beta$-TCP + HA [111-126] or $\alpha$-TCP + HA [8-12]) [127-136]. One should note that recently the concept of $\mathrm{BCP}$ has been extended by preparation and characterization of biphasic TCP (BTCP), consisting of both $\alpha$-TCP and $\beta$-TCP phases [137-141]. The biphasic TCP is usually prepared by heating ACP precursors [139-141], in which the $\alpha$ $\mathrm{TCP} / \beta$-TCP ratio can be controlled by aging time and $\mathrm{pH}$ value during synthesis of the amorphous precursor [140]. Furthermore, a triphasic formulation, consisting of HA, $\alpha$-TCP and $\beta$-TCP has been prepared [142].

The preparation techniques of various calcium orthophosphates have been extensively reviewed in literature [86, 143-151 and references therein]. When compared to both $\alpha$ - and $\beta$-TCP, HA is a more stable phase under the physiological conditions, as it has a lower solubility (Table 1) and thus a slower resorption kinetics $[64,127,128]$. Therefore, the BCP concept is determined by the optimum balance of a more stable phase of HA and a more soluble TCP. Due to a higher biodegradability of the $\alpha$ - or $\beta$-TCP component, the reactivity of BCP increases with the TCP/HA ratio. Therefore, in vivo bioresorbability of BCP can be controlled through the phase composition [120]. Similar conclusions are also valid for both the biphasic TCP (in which $\alpha$-TCP is a more soluble phase) and the triphasic (HA, $\alpha$-TCP and $\beta$-TCP) formulation.

As implants made of sintered HA are found in bone defects for many years after implantation (Fig. 2, bottom), bioceramics made of more soluble calcium orthophosphates $[8-12,111-126,129-142,152-154]$ is preferable for the biomedical purposes (Fig. 2, top). Furthermore, the experimental results showed that BCP had a higher ability to adsorb fibrinogen, insulin or type I collagen than HA [155]. Based on both observed and measured bone formation parameters, different calcium orthophosphates have been ranked as follows: low sintering temperature $\mathrm{BCP}$ (rough and smooth) $\approx$ medium sintering temperature $\mathrm{BCP} \approx \mathrm{TCP}>$ calcined low sintering temperature $\mathrm{HA}>$ non-calcined low sintering temperature $\mathrm{HA}>$ high sintering temperature BCP (rough and smooth) $>$ high sintering temperature HA [156]. This sequence has been developed in year 2000 and thus neither biphasic TCP and nor triphasic (HA, $\alpha$-TCP and $\beta$-TCP) formulations have been included. Recent developments in processing and surface modification of HA have been reviewed elsewhere [157].

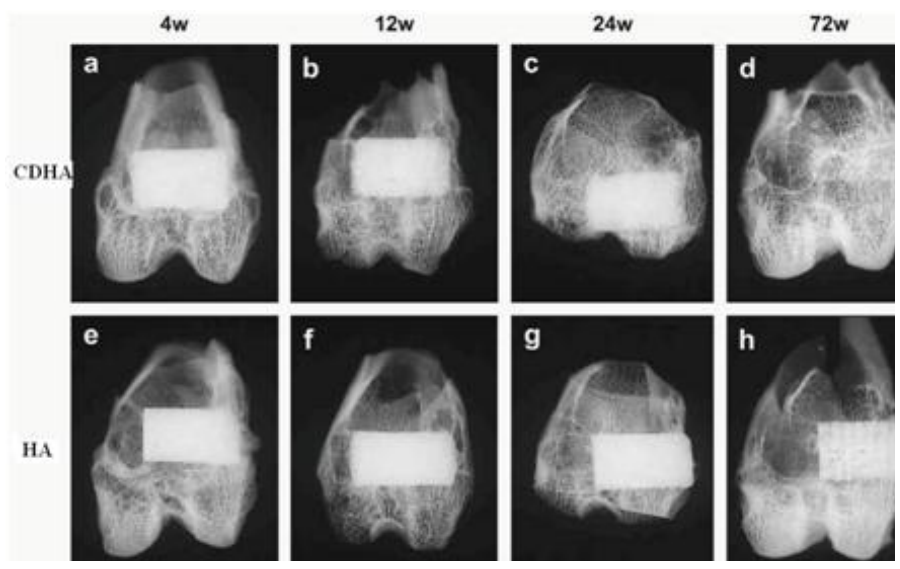

Fig. 2. Soft X-ray photographs of the operated portion of the rabbit femur. Four weeks (a), 12 weeks (b), 24 weeks (c) and 72 weeks (d) after implantation of CDHA; 4 weeks (e), 12 weeks (f), 24 weeks (g) and 72 weeks (h) after implantation of sintered HA. Reprinted from Ref. [152] with permission. 
3.3. Forming and shaping In order to fabricate bioceramics in progressively complex shapes, scientists are investigating both old and new manufacturing techniques. These techniques range from an adaptation of the age-old pottery techniques to the latest manufacturing methods for high-temperature ceramic parts for airplane engines. For example, reverse engineering and rapid prototyping technologies have revolutionized a generation of physical models, allowing an engineer to efficiently and accurately produce physical models and customized implants with high levels of geometric intricacy [158-160]. Combined with the computer-aided design and manufacturing (CAD/CAM), complex physical objects of the anatomical structure can be fabricated in a variety of shapes and sizes. In a typical application, an image of a bone defect in a patient can be taken and used to develop a three-dimensional (3D) CAD computer model [161164]. A computer can then reduce the model to slices or layers. The 3D objects are constructed layer-by-layer using rapid prototyping techniques such as fused deposition modeling $[165,166]$, selective laser sintering [167-169], laser cladding [170], 3D printing [171-180], solid freeform fabrication [181-185] and/or stereo lithography [186-189]. Furthermore, a thermal printing process of melted calcium orthophosphates has been proposed as well [190]. A custom-made implant of actual dimensions would reduce the time taken to perform the medical implantation procedure and subsequently lower the risk to the patient. Another advantage of a prefabricated, exact-fitting implant is that it can be used more effectively and applied directly to the damaged site rather than a replacement, which is formulated during surgery from a paste or granular material [182, 191, 192]. In some cases, laser processing might be applied as well [193].

The manufacturing technique depends greatly on the ultimate application of the bioceramic device, whether it is for a hard-tissue replacement or an integration of the device within the surrounding tissues. In general, three types of the processing technologies might be used: (1) employment of a lubricant and a liquid binder with ceramic powders for shaping and subsequent firing; (2) application of self-setting and self-hardening properties of water-wet molded powders; (3) materials are melted to form a liquid and are shaped during cooling and solidification [194-197]. Since calcium orthophosphates are either thermally unstable (MCPM, MCPA, DCPA, DCPD, OCP, ACP, CDHA) or have a melting point at temperatures exceeding $\sim 1400{ }^{\circ} \mathrm{C}$ with a partial decomposition ( $\alpha$-TCP, $\beta$-TCP, HA, FA, TTCP), only the first and the second consolidation approaches are used to prepare bulk bioceramics and scaffolds. The methods include uniaxial compaction [198, 199], isostatic pressing (cold or hot) [200-206], granulation [207, 208], loose packing [209], slip casting [210-213], gel casting [188, 189, 214-219], pressure mold forming [220], injection molding [221], polymer replication [222-225], extrusion [226-228], slurry dipping and spraying [229], as well as to form ceramic sheets from slurries tape casting $[124,216,230,231]$ doctor blade [232] and colander methods might be employed [194197, 233]. A combination of several techniques is also possible [216, 234]. Furthermore, some of these processes might be performed under the magnetic field, which helps crystal aligning [235-238].

Powders are usually pressed damp in metal dies or dry in lubricated dies at pressures high enough to form sufficiently strong structures to hold together until they are sintered. An organic binder such as polyvinyl alcohol helps to bind the powder together [200]. Drying at about $100{ }^{\circ} \mathrm{C}$ is a critical step in preparing damp-formed pieces for firing. Too much or too little water in the compacts can lead to blowing apart the ware on heating or crumbling, respectively. The binder is removed by heating in air to oxidize the organic phases to carbon dioxide and water [194-197].

Forming and shaping of any ceramic products also require a proper selection of the raw materials in terms of particle sizes and size distribution. Namely, tough and strong bioceramics consist of pure, fine and homogeneous microstructures. To attain this, pure powders with small average size and high surface area must be used as the starting sources. However, for maximum packing and least shrinkage after firing, mixing of $\sim 70 \%$ coarse and $\sim 30 \%$ fine powders have been suggested [197]. Mixing is usually carried out in a ball mill for uniformity of properties and reaction during subsequent firing. Mechanical die forming or sometimes extrusion through a die orifice can be used to produce a fixed cross-section. Drying involves removal of water and subsequent shrinkage of the product. However, due to local variations in water content, warping and even cracks may be developed during drying. Dry pressing and hydrostatic molding can minimize these problems [197]. Afterwards the manufactured green samples are sintered.

Finally, machine finishing might be essential [163, 194, 239] for producing the accurate shaping necessary for the fine design of bioceramics. Unfortunately, cutting tools developed for metals are usually useless for bioceramics due to their fragility, therefore grinding and polishing appear to be the convenient finishing techniques [163, 194]. Furthermore, the surface of bioceramics might be modified by various additional 
treatments [240].

3.4. Sintering and firing A sintering (or firing) procedure appears to be of a great importance to manufacture bulk bioceramics with the required mechanical properties. Usually, this stage is carried out according to controlled temperature programs of electric furnaces in adjusted ambience of air with necessary additional gasses; however, always at temperatures below the melting points of the materials. The firing step can include temporary holds at intermediate temperatures to burn out organic binders [194-197]. The heating rate, sintering temperature and holding time depend on the starting materials. For example, in the case of HA, these values are in the ranges of $0.5-3{ }^{\circ} \mathrm{C} / \mathrm{min}, 1000-$
$1250{ }^{\circ} \mathrm{C}$ and $2-5 \mathrm{~h}$, respectively [241]. In the majority cases, sintering allows a structure to retain its shape. However, this process might be accompanied by a considerable degree of shrinkage [94, 242-244], which must be accommodated in the fabrication process. For instance, in the case of FA sintering, a linear shrinkage was found to occur at $\sim 715^{\circ} \mathrm{C}$ and the material reached its final density at $\sim 890{ }^{\circ} \mathrm{C}$. Above this value, grain growth became important and induced an intra-granular porosity, which was responsible for density decrease. At $\sim 1180{ }^{\circ} \mathrm{C}$, a liquid phase was formed due to formation of a binary eutectic between FA and fluorite contained in the powder as impurity. This liquid phase further promoted the coarsening process and induced formation of large pores at high temperatures [245].

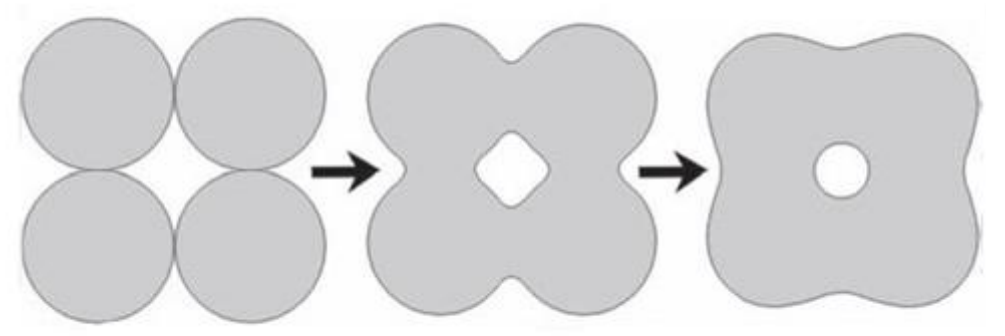

Fig. 3. A schematic diagram representing the changes occurring with particles under sintering.

The sintering mechanism is controlled by both surface and volume diffusion at grain boundaries. In general, when solids are heated to high temperatures, the constituent ions or atoms are driven to move to fill up pores and open channels between the grains of powders, as well as to compensate for the surface energy differences among their convex and concave surfaces. At the initial stages, bottlenecks are formed and grow among the particles (Fig. 3). Existing vacancies tend to flow away from the surfaces of sharply curved necks; this is an equivalent of a material flow towards the necks, which grow as the voids shrink. Small contact areas among the particles expand and, at the same time, a density of the compact increases and the total void volume decreases. As the pores and open channels are closed during a heat treatment, the particles become tightly bonded together and density, strength and fatigue resistance of the sintered object improve greatly. Grainboundary diffusion was identified as the dominant mechanism for densification [246]. Furthermore, strong chemical bonds are formed among the particles and loosely compacted green bodies are hardened to denser materials [194-197].

In the case of calcium orthophosphates, several specific processes occur during sintering. Firstly, mois- ture, carbonates and all other volatile chemicals remaining from the synthesis stage, such as ammonia, nitrates and any organic compounds, are removed as gaseous products. Secondly, unless powders are sintered, the removal of these gases facilitates production of denser ceramics with subsequent shrinkage of the samples (Fig. 4). Thirdly, all chemical changes are accompanied by a concurrent increase in crystal size and a decrease in the specific surface area. Fourthly, a chemical decomposition of all acidic orthophosphates and their transformation into other phosphates (e.g., $\left.2 \mathrm{HPO}_{4}^{2-} \rightarrow \mathrm{P}_{2} \mathrm{O}_{7}^{4-}+\mathrm{H}_{2} \mathrm{O} \uparrow\right)$ takes place. Besides, sintering causes toughening [247], densification [248, 249], partial dehydroxylation (in the case of HA) [249], as well as it increases the mechanical strength [250, 251]. The latter events are due to presence of air and other gases filling gaps among the particles of unsintered powders. At sintering, the gases move towards the outside of powders and green bodies shrink owing to decrease of distances among the particles. For example, sintering of a biologically formed apatites was investigated $[252,253]$ and the obtained products were characterized [254, 255]. In all cases, the numerical value of $\mathrm{Ca} / \mathrm{P}$ ratio in sintered apatites of biological origin was higher than that of the stoichiometric HA. 
One should mention that in the vast majority cases, calcium orthophosphates with $\mathrm{Ca} / \mathrm{P}$ ratio $<1.5$ (Table 1 ) are not sintered, since these compounds are thermally unstable, while sintering of CDHA and ACP leads to their transformation into various types of BCP (HA $+\beta$ TCP [121], HA $+\alpha$-TCP [136], $\alpha$-TCP + $\beta$-TCP [139141]).

An extensive study on the effects of sintering temperature and time on the properties of HA bioceramics revealed a correlation between these parameters and density, porosity, grain size, chemical composition and strength of the scaffolds [256]. Namely, sintering below $\sim 1000{ }^{\circ} \mathrm{C}$ was found to result in initial particle coalescence, with little or no densification and a significant loss of the surface area and porosity. The degree of densification appeared to depend on the sintering temperature whereas the degree of ionic diffusion was governed by the period of sintering [256]. To enhance sinterability of calcium orthophosphates, a variety of sintering additives might be added [257-260].

HA powders can be pressurelessly sintered up to the theoretical density at $1000-1200{ }^{\circ} \mathrm{C}$. Processing at higher temperatures may lead to exaggerated grain growth and decomposition because HA becomes unstable at temperatures exceeding $1300{ }^{\circ} \mathrm{C}[64,86$, 145-151, 261]. The decomposition temperature of HA bioceramics is a function of the partial pressure of water vapor. Moreover, processing under vacuum leads to an earlier decomposition of $\mathrm{HA}$, while processing under high partial pressure of water prevents from the decomposition. On the other hand, a presence of water in the sintering atmosphere was reported to inhibit densification of HA and accelerated grain growth [233, 262]. Unexpectedly, but application of a magnetic field during sintering was found to influence the growth of HA grains [263]. A definite correlation between hardness, density and a grain size in sintered HA bioceramics was found: despite exhibiting high bulk density, hardness started to decrease at a certain critical grain size limit [264-266].

Hot pressing [266-272], hot isostatic pressing [204, 205] or hot pressing with post-sintering [273, 274] processes make it possible to decrease a temperature of the densification process, diminish the grain size, as well as achieve higher densities. This leads to finer microstructures, higher thermal stability and subsequently better mechanical properties of calcium orthophosphate bioceramics. Microwave [108, 275-283] and spark plasma [284-292] sintering techniques are alternative methods to the conventional sintering, hot pressing and hot isostatic pressing. Both alternative methods were found to be time and energy efficient densification techniques. Further developments are still possible. For example, a hydrothermal hot pressing method has been developed to fabricate both OCP [293] and CDHA [294] bulk bioceramics with neither thermal dehydration nor thermal decomposition. Further details on the sintering and firing processes of calcium orthophosphate bioceramics are available in literature [50, 64, 146, 233, 295, 296].

To extend knowledge on the ceramic processing, all interested readers are referred to an excellent review paper on various ceramic manufacturing techniques [297].

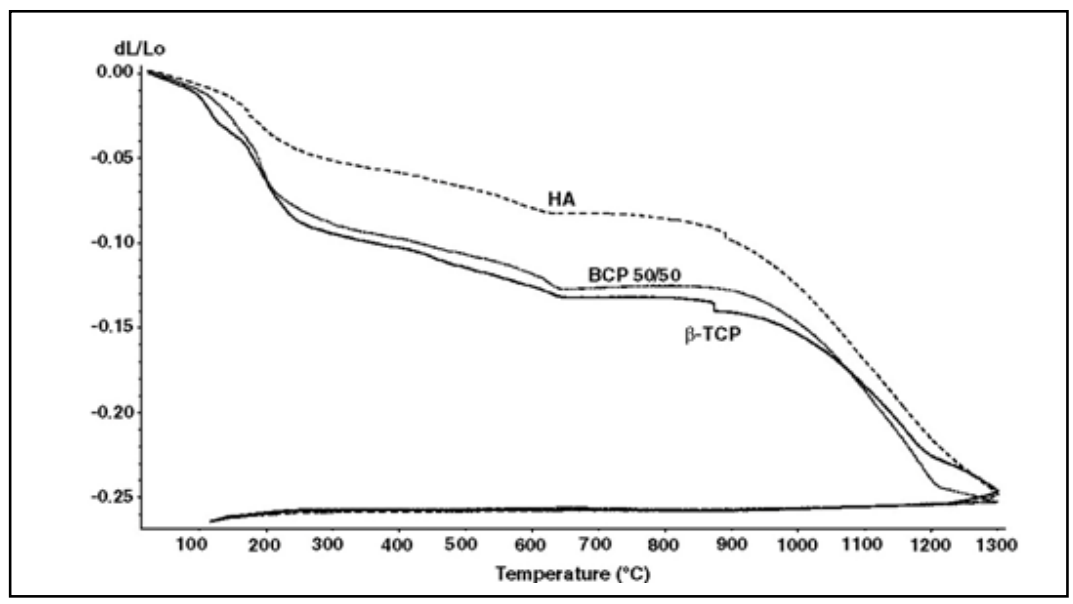

Fig. 4. Linear shrinkage of the compacted ACP powders that were converted into $\beta$-TCP, BCP $(50 \% \mathrm{HA}+50 \% \beta-\mathrm{TCP})$ and HA upon heating. According to the authors: "At $1300{ }^{\circ} \mathrm{C}$, the shrinkage reached a maximum of approximately $\sim 25, \sim 30$ and $\sim$ $35 \%$ for the compacted ACP powders that converted into HA, BCP 50/50 and $\beta$-TCP, respectively" [243]. Reprinted from Ref. [243] with permission. 


\section{The major properties}

4.1. Mechanical properties A human body provides one of the most inhospitable environments for the implanted materials. It is warm, wet and both chemically and biologically active. For example, a diversity of body fluids in various tissues might have a solution $\mathrm{pH}$ varying from 1 to 9 . Furthermore, the body is capable of generating quite massive force concentrations and the variance in such characteristics among individuals might be enormous. Typically, bones are subjected to approximately $4 \mathrm{MPa}$, whereas tendons and ligaments experience peak stresses in the range $40-80 \mathrm{MPa}$. The hip joints are subjected to an average load up to three times body weight $(3,000 \mathrm{~N})$ and peak loads experienced during jumping can be as high as 10 times body weight. These stresses are repetitive and fluctuating depending on the nature of the activities, which can include standing, sitting, jogging, stretching and climbing. Therefore, all types of potential biomaterials and bioceramics must sustain attacks of a great variety of aggressive conditions [298]. An ideally bone substitute should be replaced by a mature bone without transient loss of mechanical support. Regrettably, there is presently no material fulfilling all these requirements.

Another challenge of implanting bioceramics is that, any ceramics, when they fail, tend to do so in a dramatic manner. The brittle nature of calcium orthophosphate bioceramics is attributed to high strength ionic bonds. Thus, it is not possible for plastic deformation to happen prior to failure, as slip cannot occur. Consequently, if a crack is initiated, its progress will not be hindered by the deformation of material ahead of the crack, as would be the case in a ductile material (e.g., a metal). In ceramics, the crack will continue to propagate, rapidly resulting in a catastrophic failure [195].

For dense bioceramics, the strength is a function of the grain sizes. It appears to be very sensitive to a slow crack growth [299]. Finer grain size bioceramics have smaller flaws at the grain boundaries and thus are stronger than one with larger grain sizes. In general, the mechanical properties decrease significantly with increasing content of an amorphous phase, microporosity and grain sizes, while a high crystallinity, a low porosity and small grain sizes tend to give a higher stiffness, a higher compressive and tensile strength and a greater fracture toughness. Accordingly, from the mechanical point of view, calcium orthophosphate bioceramics appear to be brittle polycrystalline materials for which the mechanical properties are governed by crystallinity, grain size, grain boundaries, porosity and composition [203]. Thus, it possesses poor mechanical properties (for instance, a low impact and fracture resistances) that do not allow calcium orthophosphate bioceramics to be used in load- bearing areas, such as artificial teeth or bones [49-55, 300]. For example, fracture toughness [301] of HA bioceramics does not exceed the value of $\sim 1.2 \mathrm{MPa} \cdot \mathrm{m}^{1 / 2}$ [302] (human bone: $2-12 \mathrm{MPa} \cdot \mathrm{m}^{1 / 2}$ ). It decreases almost linearly with a porosity increasing [233]. Generally, fracture toughness increases with grain size decreasing. However, in some materials, especially noncubic ceramics, fracture toughness reaches the maximum and rapidly drops with decreasing grain size. For example, Halouani, et al., investigated a fracture toughness of pure hot pressed HA with grain sizes between $0.2-1.2 \mu \mathrm{m}$. They found two distinct trends, where fracture toughness decreased with increasing grain size above $\sim 0.4 \mu \mathrm{m}$ and subsequently decreased with decreasing grain size. The maximum fracture toughness

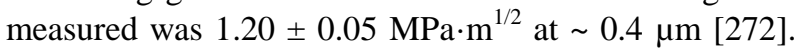
Fracture energy of HA bioceramics is in the range of 2.3 $-20 \mathrm{~J} / \mathrm{m}^{2}$, while the Weibull modulus [303] is low ( 512) in wet environments, which means that HA behaves as a typical brittle ceramics and indicates to a low reliability of HA implants [233]. Interestingly, but 3 peaks of internal friction were found at temperatures about $-40,80$ and $130{ }^{\circ} \mathrm{C}$ for $\mathrm{HA}$ but no internal friction peaks were obtained for FA in the measured temperature range; this effect was attributed to the differences of $\mathrm{F}^{-}$ and $\mathrm{OH}^{-}$positions in FA and $\mathrm{HA}$, respectively [304].

Bending, compressive and tensile strengths of dense HA bioceramics are in the ranges of $38-250 \mathrm{MPa}, 120$ - $900 \mathrm{MPa}$ and 38 - $300 \mathrm{MPa}$, respectively. Similar values for porous HA bioceramics are in the ranges of 2 - $11 \mathrm{MPa}, 2-100 \mathrm{MPa}$ and $~ 3 \mathrm{MPa}$, respectively [233]. These wide variations in the properties are due to both structural variations (e.g., an influence of remaining microporosity, grain sizes, presence of impurities, etc.) and manufacturing processes, as well as they are caused by a statistical nature of the strength distribution. Strength [305] was found to increase with $\mathrm{Ca} / \mathrm{P}$ ratio increasing, reaching the maximum value around $\mathrm{Ca} / \mathrm{P}$ 1.67 (stoichiometric HA) and decreases suddenly when $\mathrm{Ca} / \mathrm{P}>1.67$ [233]. Furthermore, strength decreases almost exponentially with porosity increasing $[112,113]$. However, by changing the pore geometry, it is possible to influence the strength of porous bioceramics. It is also worth mentioning that porous HA bioceramics is considerably less fatigue [306] resistant than dense ones. Both grain sizes and porosity are reported to influence the fracture path, which itself has a little effect on the fracture toughness of calcium orthophosphate bioceramics [203, 307]. Furthermore, no obvious decrease in mechanical properties was found after calcium orthophosphate bioceramics had been aged in the various solutions during the different time periods [308]. 
Young's (or elastic) modulus [309] of dense HA bioceramics is in the range of $35-120 \mathrm{GPa}$, which is more or less similar to those of the most resistant components of the natural calcified tissues (dental enamel: $74 \mathrm{GPa}$, dentine: $21 \mathrm{GPa}$, compact bone: $18-22 \mathrm{GPa}$ ). Nevertheless, dense bulk compacts of HA have mechanical resistances of the order of $100 \mathrm{MPa}$ versus $300 \mathrm{MPa}$ of human bones, diminishing drastically their resistances in the case of porous bulk compacts [310]. Young's modulus measured in bending is between 44 and $88 \mathrm{GPa}$. Recently, a considerable anisotropy in the stress-strain behavior of the perfect HA crystals was found by ab initio calculations [311]. The crystals appeared to be brittle for tension along the $z$-axis with the maximum stress of $\sim 9.6 \mathrm{GPa}$ at $10 \%$ strain. Furthermore, the structural analysis of the HA crystal under various stages of tensile strain revealed that the deformation behavior manifested itself mainly in the rotation of $\mathrm{PO}_{4}$ tetrahedrons with concomitant movements of both the columnar and axial $\mathrm{Ca}$ ions [311]. Vickers hardness [312] of dense HA bioceramics is within 3-7 GPa, while the Poisson's ratio [313] for the synthetic HA is about 0.27 , which is close to that of bones $(\sim 0.3)$. At temperatures within $1000-1100{ }^{\circ} \mathrm{C}$, dense HA bioceramics was found to exhibit superplasticity with a deformation mechanism based on grain boundary sliding. Furthermore, both wear resistance and friction coefficient of dense HA bioceramics are comparable to those of dental enamel [233].

Due to a high brittleness (associated to a low crack resistance), the biomedical applications of calcium orthophosphate bioceramics are focused on production of non-load-bearing implants, such as pieces for middle ear surgery, filling of bone defects in oral or orthopedic surgery, as well as coating of dental implants and metallic prosthesis (see below) $[110,314,315]$. In order to improve the reliability of calcium orthophosphate bioceramics, diverse reinforcements (ceramics, metals or polymers) have been applied to manufacture various biocomposites and hybrid biomaterials [316], however, successful hybrid formulations consisted of calcium orthophosphates only should be mentioned [317-322] here. For example, bulk HA bioceramics might be reinforced by HA whiskers [318-321]. Furthermore, a superior superplasticity of $\mathrm{HA} / \beta-\mathrm{TCP}$ biocomposites (i.e., BCP) to HA bioceramics has been detected [322].

Another approach to improve the mechanical properties of calcium orthophosphate bioceramics is to coat the items by a polymeric layer [323, 324], however this is still other stories beyond this review. Further details on the mechanical properties of calcium orthophosphate bioceramics are available elsewhere [233, 325].
4.2. Electrical properties Some interests in the electrical properties of calcium orthophosphate bioceramics has been occasionally expressed. For example, a surface ionic conductivity of both porous and dense HA bioceramics was examined for humidity sensor applications, since the room temperature conductivity was influenced by relative humidity [326]. Namely, the ionic conductivity of HA has been a subject of research for its possible use as an alcohol [327], carbon dioxide [327] or carbon monoxide [328] gas sensors. Electrical measurements have also been used as a characterization tool to study the evolution of microstructure in HA bioceramics [329]. More to the point, Valdes et al., examined the dielectric properties of HA to understand its decomposition to $\beta$-TCP [330]. In the case of CDHA, the electrical properties, in terms of ionic conductivity, were found to increase after compression of the samples at $15 \mathrm{t} / \mathrm{cm}^{2}$, which was attributed to establishment of some order within the apatitic network [331]. The conductivity mechanism of CDHA appeared to be multiple [332]. Furthermore, there was an attempt to develop CDHA whisker electrets for biomedical utilization [333].

Interestingly the electrical properties of calcium orthophosphate bioceramics appear to influence their biomedical applications. For example, there is an interest in polarization of HA bioceramics to generate a surface charge by the application of electric fields at elevated temperatures $[334,335]$. The presence of surface charges on HA bioceramics was shown to have a significant effect on both in vitro and in vivo crystallization of biological apatite [336-340]. Furthermore, a growth of both biomimetic calcium orthophosphates and bones was found to be accelerated on negatively charged surfaces and decelerated at positively charged surfaces [340-349]. In addition, the electrical polarization of HA bioceramics was found to accelerate a cytoskeleton reorganization of osteoblastlike cells [350-352], extend bioactivity [353] and enhance bone ingrowth through the pores of porous HA implants [354]. There is an interesting study on the interaction of a blood coagulation factor on electrically polarized HA surfaces [355]. Further details on the electrical properties of calcium orthophosphate-based bioceramics are available in literature [279, 356-360].

4.3. Possible transparency Single crystals of all calcium orthophosphates are optically transparent for the visible light. As bioceramics of calcium orthophosphates have a polycrystalline nature with a random orientation of big amounts of small crystals, it is opaque and of white color, unless colored dopants have 
been added. However, in some cases, a transparency is convenient to provide some essential advantages (e.g., to enable direct viewing of living cells, their attachment, spreading, proliferation, and osteogenic differentiation cascade in a transmitted light). Thus, transparent calcium orthophosphate bioceramics (Fig. 5) [361] have been prepared and investigated [204, 206, 289, 292, 361-370]. They can exhibit an optical transmittance of $66 \%$ at a wavelength of $645 \mathrm{~nm}$ [370]. The preparation techniques, for example, include a hot isostatic pressing [204, 206], an ambient-pressure sintering [362], gel casting coupled with a low-temperature sintering [365, 368], a pulse electric current sintering [366], as well as a spark plasma sintering [289, 292]. Fully dense, transparent calcium orthophosphate bioceramics was obtained at temperatures above $\sim 800{ }^{\circ} \mathrm{C}$. Depending on the preparation technique, the transparent bioceramics has a uniform grain sizes ranging from $\sim 81 \mathrm{~nm} \mathrm{[370]} \mathrm{to}$ $\sim 250 \mu \mathrm{m}[365]$ and always is pore-free. Furthermore, a translucent calcium orthophosphate bioceramics is also known [371-373]. However, due to a lack of both porosity and the necessity to have see-through implants inside the body, the transparent and/or translucent forms of calcium orthophosphate bioceramics will hardly be ever used in medicine with the specific eye implants as the only reasonable exception.

4.4. Porosity Porosity is defined as a percentage of void spaces in solids and it is a morphological property independent of the material. The surface area of porous bodies is much higher, which guarantees a good mechanical fixation in addition to providing sites on the surface that allow chemical bonding between the bioceramics and bones [374]. Furthermore, a porous material may have both closed (isolated) pores and open (interconnected) pores. The interconnected pores look

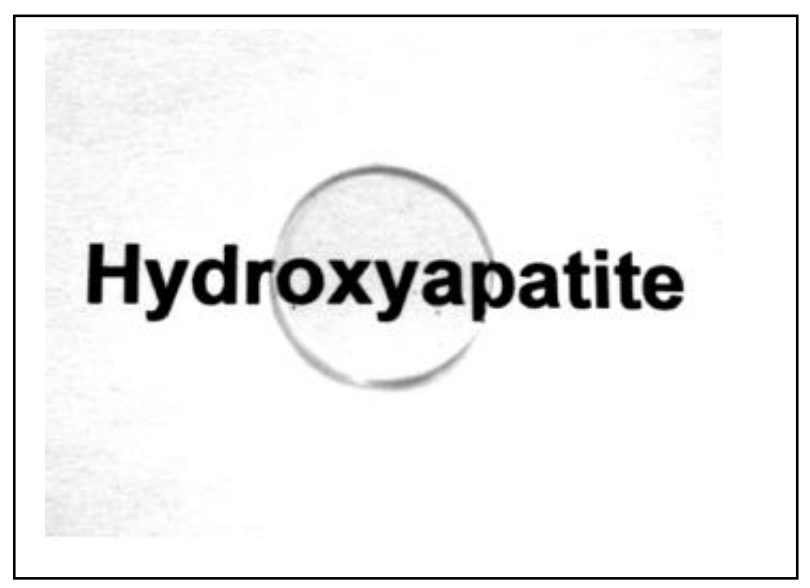

like tunnels and are accessible by gases, liquids and particulate suspensions [375]. The open-cell nature of reticulated materials is a unique characteristic essential in many applications. Furthermore, dimensions of open pores are directly related to bone formation, since such pores grant both the surface and space for cell adhesion and bone ingrowth. On the other hand, pore interconnection provides the ways for cell distribution and migration, as well as it allows an efficient in vivo blood vessel formation suitable for sustaining bone tissue neo-formation and possibly remodeling [155, 376385]. Namely, porous HA bioceramics can be colonized by bone tissues [381, 386-396]. Therefore, interconnecting macroporosity (pore size $>100 \mu \mathrm{m}$ ) [111, 374, 381, 397, 398], which is defined by its capacity to be colonized by cells, is intentionally introduced in solid bioceramics (Fig. 6). Macroporosity is usually formed due to a release of various volatile materials and, for that reason, incorporation of porecreating additives (porogens) is the most popular technique to create macroporosity. The porogens are crystals or particles of either volatile (they evolve gases at elevated temperatures) or soluble substances, such as paraffin, naphthalene, sucrose, $\mathrm{NaHCO}_{3}$, gelatin, polymethylmethacrylate or even hydrogen peroxide [112, 295, 400-407]. Obviously, the ideal porogen should be nontoxic and be removed at ambient temperature, thereby allowing the ceramic/porogen mixture to be injected directly into a defect site and allowing the scaffold to fit the defect [408]. Sintering particles, preferably spheres of equal size, is a similar way to generate porous $3 \mathrm{D}$ bioceramics of calcium orthophosphates (Fig. 7). However, pores resulting from this method are often irregular in size and shape and not fully interconnected with one another.

Fig. 5. Transparent HA bioceramics prepared by spark plasma sintering at $900^{\circ} \mathrm{C}$ from nanosized HA single crystals. Reprinted from Ref. [361] with permission. 

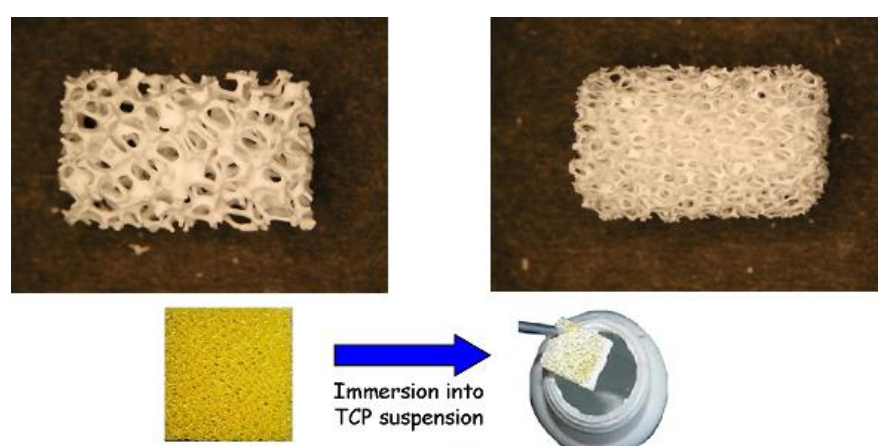

Polyurethane foam

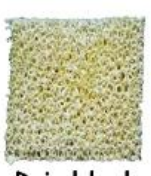

Dried body

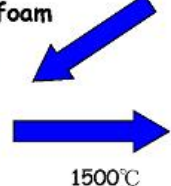

$1500^{\circ} \mathrm{C}$
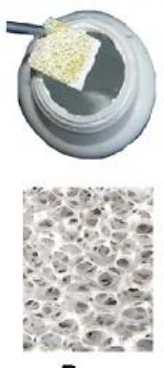

Foam

Fig. 6. Photographs of a commercially available porous calcium orthophosphate bioceramics with different porosity (top) and a method of their production (bottom). For photos, the horizontal field width is $20 \mathrm{~mm}$. The bottom picture is reprinted from Ref. [399] with permission.

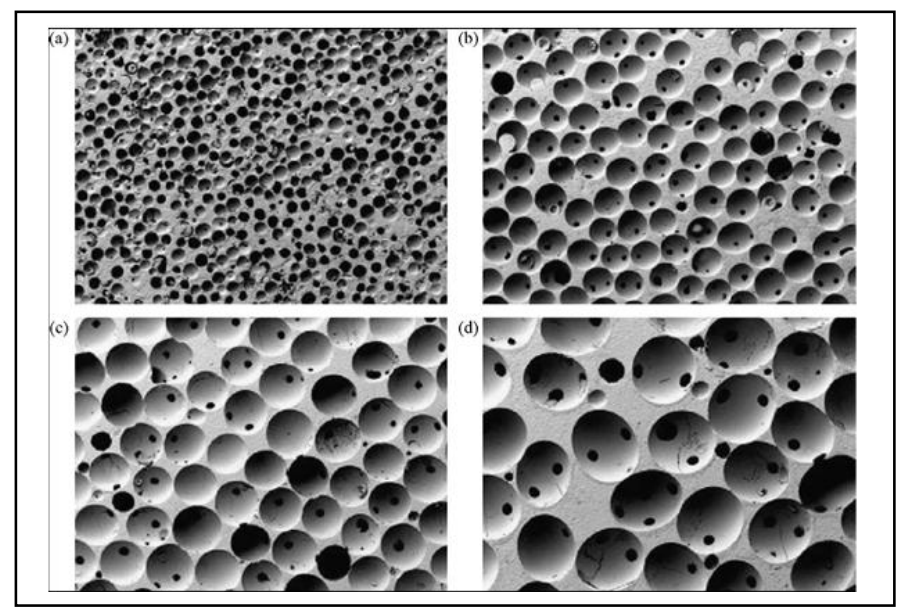

Fig. 7. $\beta$-TCP porous ceramics with different pore sizes prepared using polymethylmethacrylate balls with diameter equal to: (a) 100-200, (b) 300-400, (c) 500-600 and (d) 700$800 \mu \mathrm{m}$. Horizontal field width is $45 \mathrm{~mm}$. Reprinted from Ref. [411] with permission.

Table 2. The procedures used to manufacture porous calcium orthophosphate scaffolds for tissue engineering [408].

\begin{tabular}{|c|c|c|c|c|c|c|c|c|}
\hline Year & Location & Process & Apatite from: & Sintering & $\begin{array}{l}\text { Compressive } \\
\text { strength }\end{array}$ & Pore size & Porosity & Method of porosity control \\
\hline 2006 & $\begin{array}{l}\text { Deville et al. } \\
\text { Berkeley, CA }\end{array}$ & $\begin{array}{l}\text { HA + ammonium methacrylate in } \\
\text { PTFE mold, freeze dried and sintered }\end{array}$ & $\mathrm{HA} \# 30$ & Yes: $1300^{\circ} \mathrm{C}$ & $\begin{array}{l}16 \mathrm{MPa} \\
65 \mathrm{MPa} \\
145 \mathrm{MPa}\end{array}$ & $\begin{array}{c}\text { open } \\
\text { unidirectional } \\
50-150 \mu \mathrm{m}\end{array}$ & $\begin{array}{c}>60 \% \\
56 \% \\
47 \%\end{array}$ & $\begin{array}{l}\text { Porosity control: slurry conc. Structure controlled by } \\
\text { physics of ice front formation. }\end{array}$ \\
\hline 2006 & $\begin{array}{l}\text { Saiz et al. } \\
\text { Berkeley, CA }\end{array}$ & $\begin{array}{l}\text { Polymer foams coated, compressed } \\
\text { after infiltration, then calcined. }\end{array}$ & HA powder & $\begin{array}{l}\text { Yes: } 700- \\
1300{ }^{\circ} \mathrm{C}\end{array}$ & - & $100-200 \mu \mathrm{m}$ & - & Porosity control: extent of compression, HA loading \\
\hline
\end{tabular}


Sergey V. Dorozhkin / BIO 2011, 1, 1-51 @CCAAS

\begin{tabular}{|c|c|c|c|c|c|c|c|c|}
\hline Year & Location & Process & Apatite from: & Sintering & $\begin{array}{l}\text { Compressive } \\
\text { strength }\end{array}$ & Pore size & Porosity & Method of porosity control \\
\hline 2006 & $\begin{array}{l}\text { Murugan et al. } \\
\text { Singapore }+ \\
\text { USA }\end{array}$ & Bovine bone cleaned, calcined & bovine bone & Yes: $500{ }^{\circ} \mathrm{C}$ & - & $\begin{array}{c}\text { retention of } \\
\text { nano-sized } \\
\text { pores }\end{array}$ & - & Porosity control: native porosity of bovine bone \\
\hline 2006 & $\begin{array}{c}\text { Xu et al. } \\
\text { Gaithersburg, } \\
\text { MD }\end{array}$ & $\begin{array}{c}\text { Directly injectable calcium } \\
\text { orthophosphate cement, self hardens, } \\
\text { mannitol as porogen }\end{array}$ & $\begin{array}{c}\text { nanocrystalline } \\
\text { HA }\end{array}$ & No & $\begin{array}{l}2.2-4.2 \mathrm{MPa} \\
\quad \text { (flexural) }\end{array}$ & $\begin{array}{c}0-50 \% \\
\text { macroporous }\end{array}$ & $65-82 \%$ & Porosity control: mannitol mass fraction in mixture \\
\hline 2004 & $\begin{array}{l}\text { Landi et al. } \\
\text { Italy }+ \\
\text { Indonesia }\end{array}$ & $\begin{array}{c}\text { Sponge impregnation, isotactic } \\
\text { pressing, sintering of HA in simulated } \\
\text { body fluid }\end{array}$ & $\mathrm{CaO}+\mathrm{H}_{3} \mathrm{PO}_{4}$ & $\begin{array}{l}\text { Yes: } 1250^{\circ} \mathrm{C} \\
\text { for } 1 \mathrm{hr}\end{array}$ & $23 \pm 3.8 \mathrm{MPa}$ & $\begin{array}{l}\text { closed 6\% } \\
\text { open 60\% }\end{array}$ & $66 \%$ & $\begin{array}{l}\text { Porosity control: possibly by controlling HA particle } \\
\text { size. Not suggested by authors }\end{array}$ \\
\hline 2003 & $\begin{array}{l}\text { Charriere et al. } \\
\text { EPFL, } \\
\text { Switzerland }\end{array}$ & $\begin{array}{l}\text { Thermoplastic negative porosity by } \\
\text { Ink jet printing, slip casting process } \\
\text { for HA }\end{array}$ & DCPA + calcite & $\begin{array}{c}\text { No: } 90^{\circ} \mathrm{C} \text { for } 1 \\
\text { day }\end{array}$ & $12.5 \pm 4.6 \mathrm{MPa}$ & - & $44 \%$ & Porosity control: negative printing \\
\hline 2003 & $\begin{array}{l}\text { Almirall et al. } \\
\text { Barcelona, } \\
\text { Spain }\end{array}$ & $\begin{array}{c}\alpha \text {-TCP foamed with hydrogen } \\
\text { peroxide at different conc., liq. ratios, } \\
\text { poured in PTFE molds }\end{array}$ & $\begin{array}{r}\alpha-\mathrm{TCP}+(10 \% \\
\left.\text { and } 20 \% \mathrm{H}_{2} \mathrm{O}_{2}\right)\end{array}$ & $\begin{array}{c}\text { No: } 60{ }^{\circ} \mathrm{C} \text { for } 2 \\
\mathrm{hr}\end{array}$ & $\begin{array}{l}1.41 \pm 0.27 \mathrm{MPa} \\
2.69 \pm 0.91 \mathrm{MPa}\end{array}$ & $\begin{array}{l}35.7 \% \text { macro } \\
29.7 \% \text { micro } \\
26.8 \% \text { macro } \\
33.8 \% \text { micro }\end{array}$ & $\begin{array}{l}65.5 \% \\
60.7 \%\end{array}$ & $\begin{array}{l}\text { Porosity control: different concentration, } \alpha \text {-TCP particle } \\
\text { sizes }\end{array}$ \\
\hline 2003 & $\begin{array}{l}\text { Ramay et al. } \\
\text { Seattle, WA }\end{array}$ & $\begin{array}{l}\text { Slurries of HA prepared: gel-casting + } \\
\text { polymer sponge technique, sintered. }\end{array}$ & HA powder & $\begin{array}{l}\text { Yes: } 600{ }^{\circ} \mathrm{C} \\
\text { for } 1 \mathrm{hr} 1350 \\
{ }^{\circ} \mathrm{C} \text { for } 2 \mathrm{hr}\end{array}$ & $0.5-5 \mathrm{MPa}$ & $200-400 \mu \mathrm{m}$ & $70-77 \%$ & Porosity control: replicate of polymer sponge template \\
\hline 2003 & $\begin{array}{l}\text { Miao et al. } \\
\text { Singapore }\end{array}$ & $\begin{array}{l}\text { TTCP to calcium orthophosphate } \\
\text { cement cement. Slurry cast on } \\
\text { polymer foam, sintered. }\end{array}$ & TTCP & $\begin{array}{l}\text { Yes: } 1200^{\circ} \mathrm{C} \\
\text { for } 2 \mathrm{hr}\end{array}$ & - & $\begin{array}{l}1 \mathrm{~mm} \text { macro } \\
5 \mu \mathrm{m} \text { micro }\end{array}$ & $\sim 70 \%$ & Porosity control: Recoating time, polyurethane foam \\
\hline 2003 & $\begin{array}{l}\text { Uemura et al. } \\
\text { China + Japan }\end{array}$ & $\begin{array}{c}\text { Slurry of HA with } \\
\text { polyoxyethylenelaurylether (cross- } \\
\text { linked) and sintered }\end{array}$ & HA powders & $\begin{array}{l}\text { Yes: } 1200^{\circ} \mathrm{C} \\
\text { for } 3 \mathrm{hr}\end{array}$ & $\begin{array}{c}2.25 \mathrm{MPa}(0 \mathrm{wk}) \\
4.92 \mathrm{MPa}(12 \mathrm{wks}) \\
11.2 \mathrm{MPa}(24 \mathrm{wks})\end{array}$ & $\begin{array}{c}500 \mu \mathrm{m} \\
200 \mu \mathrm{m} \\
\text { interconnects }\end{array}$ & $\sim 77 \%$ & Porosity control: polymer interconnects cross-linking \\
\hline 2003 & $\begin{array}{l}\text { Ma et al. } \\
\text { Singapore + } \\
\quad \text { USA }\end{array}$ & $\begin{array}{l}\text { Electrophoretic deposition of HA, } \\
\text { sintering. }\end{array}$ & HA powders & $\begin{array}{l}\text { Yes: } 1200^{\circ} \mathrm{C} \\
\text { for } 2 \mathrm{hr}\end{array}$ & $860 \mathrm{MPa}$ & $\begin{array}{l}0.5 \mu \mathrm{m} \\
130 \mu \mathrm{m}\end{array}$ & $\sim 20 \%$ & Porosity control: electrophoresis field \\
\hline 2002 & $\begin{array}{l}\text { Barralet et al. } \\
\text { Birmingham, } \\
\text { London, UK }\end{array}$ & $\begin{array}{l}\text { Calcium orthophosphate cement }+ \\
\text { sodium phosphate ice, evaporated }\end{array}$ & $\mathrm{CaCO}_{3}+\mathrm{DCPD}$ & $\begin{array}{l}1 \text { st step: } 1400 \\
{ }^{\circ} \mathrm{C} \text { for } 1 \text { day }\end{array}$ & $0.6 \pm 0.27 \mathrm{MPa}$ & $2 \mu \mathrm{m}$ & $62 \pm 9 \%$ & Porosity control: porogen shape. \\
\hline
\end{tabular}


Several other techniques have been applied to fabricate porous calcium orthophosphate bioceramics, such as replication of polymer foams by impregnation (Fig. 6), dual-phase mixing, particulate leaching, freeze casting, slip casting, stereo lithography, direct foaming of suspensions, as well as surfactant washing [91, 195, 212, 216, 219, 222-224, 267, 268, 376-378, 397-451]. Some of them have been summarized in Table 2 [408]. Furthermore, natural porous materials, like coral skeletons made of $\mathrm{CaCO}_{3}$, can be converted into porous HA under the hydrothermal conditions $\left(250^{\circ} \mathrm{C}, 24-48\right.$ h) with the microstructure undamaged [91-93]. Porous HA bioceramics can also be obtained by hydrothermal hot pressing. This technique allows solidification of the HA powder at $100-300{ }^{\circ} \mathrm{C}(30 \mathrm{MPa}, 2 \mathrm{~h})$ [415]. In another approach, bi-continuous water-filled microemulsions have been used as pre-organized systems for the fabrication of needle-like frameworks of crystalline HA $\left(2{ }^{\circ} \mathrm{C}, 3\right.$ weeks $)[416,417]$. Porous HA bioceramics might be prepared by a combination of gel casting and foam burn out methods [219]. Lithography was used to print a polymeric material, followed by packing with HA and sintering [418]. Both hot pressing [267, 268] and ice templating [419, 785] techniques might be applied as well. Besides, an HA suspension can be cast into a porous $\mathrm{CaCO}_{3}$ skeleton, which is then dissolved, leaving a porous network [410]. 3D periodic macroporous frame of HA has been fabricated via a template-assisted colloidal processing technique [420, 421]. A superporous ( $~ 85 \%$ porosity) HA ceramics was developed as well [450, 451]. More to the point, porous HA bioceramics might prepared by using different starting HA powders and sintering at various temperatures by a pressureless-sintering approach [427].

Porous bioceramics with an improved strength might be fabricated from calcium orthophosphate fibers or whiskers. In general, fibrous porous materials are known to exhibit an improved strength due to fiber interlocking, crack deflection and/or pullout [422]. Namely, porous bioceramics with well-controlled open pores was processed by sintering of fibrous HA particles [423]. In another approach, porosity was achieved by firing apatite-fiber compacts mixed with carbon beads and agar. By varying the compaction pressure, firing temperature and carbon/HA ratio, the total porosity was controlled in the ranges from $\sim 40 \%$ to $\sim 85 \%$ [412]. Additional examples are available in literature [397, 401, 408-451].

In vivo response of calcium orthophosphate bioceramics of different porosity was investigated and a hardly any effect of macropore dimensions $(\sim 150, \sim$ 260, $\sim 510$ and $\sim 1220 \mu \mathrm{m}$ ) was observed [452]. In another study, a greater differentiation of mesenchymal stem cells was observed when cultured on $\sim 200 \mu \mathrm{m}$ pore size HA scaffolds when compared to those on $500 \mu \mathrm{m}$ pore size HA [453]. The latter finding was attributed to the fact that a higher pore volume in $\sim 500$ $\mu \mathrm{m}$ macropore scaffolds might contribute to a lack of cell confluency leading to the cells proliferating before beginning differentiation. Besides, the authors hypothesized that bioceramics having a less than the optimal pore dimensions induced quiescence in differentiated osteoblasts due to reduced cell confluency [453]. Already in 1979, Holmes suggested that the optimal pore range was $200-400 \mu \mathrm{m}$ with the average human osteon size of $\sim 223 \mu \mathrm{m}$ [92]. In 1997, Tsurga and coworkers implied that the optimal pore size of bioceramics that supported ectopic bone formation was $300-400 \mu \mathrm{m}$ [454]. Thus, there is no need to create calcium orthophosphate bioceramics with very big pores; however, the pores must be interconnected [95, 384, 397, 398]. Interconnectivity governs a depth of cells or tissue penetration into the porous bioceramics, as well as it allows development of blood vessels required for new bone nourishing and wastes removal $[455,456]$.

Bioceramic microporosity (pore size $<10 \mu \mathrm{m}$ ), which is defined by its capacity to be impregnated by biological fluids [455], results from the sintering process, while the pore dimensions mainly depend on the material composition, thermal cycle and sintering time. The microporosity provides both a greater surface area for protein adsorption and increased ionic solubility. For example, embedded osteocytes distributed throughout microporous rods might form a mechanosensory network, which would not be possible in scaffolds without microporosity [457]. HA bioceramics with nanodimensional $(<100 \mathrm{~nm})$ pores might be fabricated as well [458]. Differences in porogens influence the macroporosity, while differences in sintering temperatures and conditions affect the percentage of microporosity. Usually, the higher the sintering temperature, the lower both the microporosity content and the specific surface area of bioceramics. Namely, HA bioceramics sintered at $\sim 1200{ }^{\circ} \mathrm{C}$ shows significantly less microporosity and a dramatic change in crystal sizes, if compared with that sintered at $\sim 1050$ ${ }^{\circ} \mathrm{C}$ (Fig. 8). Furthermore, the average shape of pores was found to transform from strongly oblate to round at higher sintering temperatures [460]. The total porosity (macroporosity + microporosity) of calcium orthophosphate bioceramics was reported to be $\sim 70 \%$ [461] or $\sim 85 \%$ [450, 451] of the bioceramic volume. In the case of coralline HA or bovine-derived apatites, the porosity of the original biologic material (coral or bovine bone) is usually preserved during processing [94]. To conclude this topic, creation of the desired 
porosity in calcium orthophosphate bioceramics is a rather complicated engineering task and the interested readers are referred to other publications on this subject [112, 377, 402, 416, 462-489].

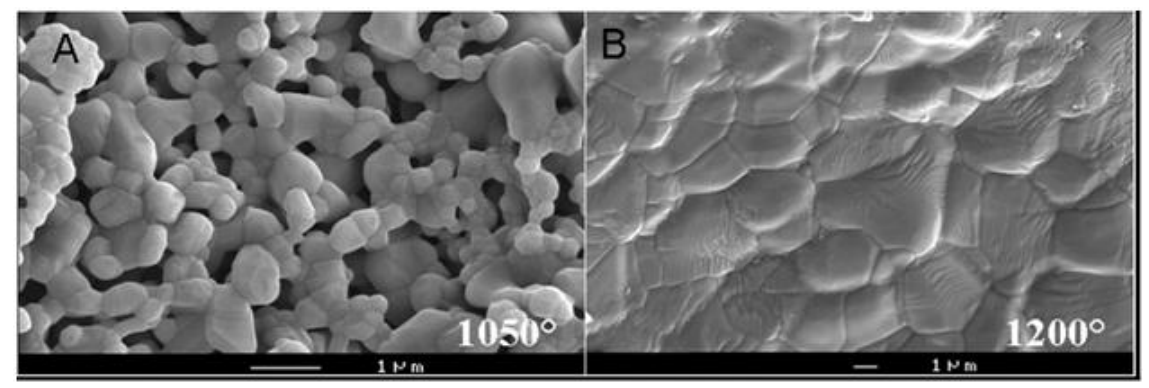

Fig. 8. SEM pictures of HA bioceramics sintered at (A) $1050^{\circ} \mathrm{C}$ and (B) $1200{ }^{\circ} \mathrm{C}$. Note the presence of microporosity in A and not in B. Reprinted from Ref. [459] with permission.
Studies revealed that increasing of both the specific surface area and pore volume of bioceramics might greatly accelerate the in vivo process of apatite deposition and, therefore, enhance the bone-forming bioactivity. More importantly, a precise control over the porosity, pore dimensions and internal pore architecture of bioceramics on different length scales is essential for understanding of the structure-bioactivity relationship and the rational design of better bone-forming biomaterials [483, 490, 491]. Namely, in antibiotic charging experiments, a calcium orthophosphate bioceramics with nanodimensional $(<100 \mathrm{~nm})$ pores showed a much higher charging capacity $(1621 \mu \mathrm{g} / \mathrm{g})$ than that of commercially available calcium orthophosphate $(100 \mu \mathrm{g} / \mathrm{g})$, which did not contain nanodimensional porosity [478]. In other experiments, porous blocks of HA were found to be viable carriers with sustained release profiles for drugs [492] and antibiotics over 12 days [493] and 12 weeks [494], respectively. Unfortunately, porosity significantly decreases the strength of implants [233, 307, 325]. Thus, porous calcium orthophosphate implants cannot be loaded and are used to fill only small bone defects. However, their strength increases gradually when bones ingrow into the porous network of calcium orthophosphate implants [495-498]. For example, Martin et al., reported bending strengths of $40-60 \mathrm{MPa}$ for a porous HA implant filled with $50-60 \%$ of cortical bone [495], while in another study an ingrown bone increased strength of porous HA bioceramics by a factor of 3 to 4 [497].

To conclude this topic, one should mention that filters for microbial filtration might be manufactured from porous HA [499].

5. Biomedical applications Since Levitt et al. described a method of preparing a FA bioceramics and suggested its possible use in medical applications in 1969 [500], calcium orthophosphate bioceramics have been widely tested for clinical applications. Namely, calcium orthophosphates in a number of forms and compositions (Table 3) currently are either in use or under a consideration in many areas of dentistry and orthopedics, with even more in development. For example, bulk materials, available in dense and porous forms, are used for alveolar ridge augmentation, immediate tooth replacement and maxillofacial reconstruction [64, 377]. Other examples include burrhole buttons [505], orbital implants $\left(\right.$ Bio-Eye $^{\circledR}$ ) [506509], other ophthalmic applications [510, 511], increment of the hearing ossicles, spine fusion and repair of bone defects $[512,513]$. In order to permit growth of new bone into defects, a suitable bioresorbable material should fill these defects, otherwise ingrowth of fibrous tissue might prevent bone formation within the defects.

In spite of the aforementioned serious mechanical limitations, bioceramics of calcium orthophosphates is available in various physical forms: powders, particles, granules (or granulates [12]), dense blocks, porous scaffolds, self-setting formulations, implant coatings and composite component of different origin (natural, biological or synthetic) often with the specific shapes, such as implants, prostheses or prosthetic devices (Table 4) $[2,95]$. Furthermore, bone grafts are also proposed as non-hardening pastes (= "putty"). Generally, the latter materials consist of a mixture of calcium orthophosphate powders or granules and a "glue", typically a highly viscous hydrogel $[2,316]$. More to the point, customdesigned shapes like wedges for tibial opening osteotomy, cones for spine and knee and inserts for vertebral cage fusion are also available [461]. Various trademarks of the commercially available types of calcium orthophosphate-based bioceramics and biomaterials have been summarized in Table 3 . 
One should note that among the existing calcium orthophosphates (Table 1), only certain compounds are useful for biomedical applications, because those having the $\mathrm{Ca} / \mathrm{P}$ ionic ratio less than 1 are not suitable for implantation due to their high solubility and acidity. Furthermore, due to its basicity, TTCP alone is not suitable either. However, to be used in medicine, these "unsuitable" calcium orthophosphates might successfully be combined with either other calcium orthophosphates or other chemicals.

5.1. Cements and concretes The need of bioceramics for minimal invasive surgery has induced the development of a concept of self-setting formulations consisting of only calcium orthophosphates to be applied as injectable and/or mouldable bone substitutes [156, 400, 401, 418, 475, 514-522]. In addition, there are reinforced formulations, which, in a certain sense, might be defined as calcium orthophosphate concretes [516]. Furthermore, porous formulations of both the cements and the concretes are available [401, 418, 515520].

Calcium orthophosphate cements and concretes belong to a low temperature bioceramics. They are divided into two major groups. The first one is a dry mixture of two different calcium orthophosphates (a basic one and an acidic one), in which, after being wetted, the setting reaction occurs according to an acid-base reaction. The second group of the cements contains only one calcium orthophosphate. Typical examples include ACP with $\mathrm{Ca} / \mathrm{P}$ molar ratio within $1.50-1.67$ and $\alpha$-TCP: they form CDHA upon contact with an aqueous solution [156, 515, 516]. The setting reaction (= hardening, curing) of these materials is initiated by mixing the initial powder(s) with an aqueous solution. Chemically, hardening is due to the succession of dissolution and precipitation reactions. Mechanically, hardening results from crystal entanglement and intergrowth (Fig. 9) [2]. Setting of calcium orthophosphate cements and concretes occurs mostly within the initial $\sim 6$ hours, yielding $\mathrm{a} \sim 80 \%$ conversion to the final products and $\mathrm{a}$ compressive strength of $40-60 \mathrm{MPa}$. A hardening rate is strongly influenced by a powder to liquid ratio, as well as by addition of other chemicals [156, 514-522]. Despite a large number of formulations, all calcium orthophosphate cements can only form two different end products: CDHA and DCPD [156, 515, 516].

All calcium orthophosphate cements and concretes are biocompatible, bioactive and bioresorbable. The first animal study of a calcium orthophosphate cement was performed in 1991. That time a cement consisting of TTCP and DCPA was investigated histologically by implanting disks made of this cement within the heads of nine cats [523, 524]. In 1996, that formulation received an approval by the US Food and Drug Administration (FDA), thus becoming the first commercially available calcium orthophosphate cement for use in humans [517]. As the structure and composition of the hardened cements is close to that of bone mineral, the material of the hardened cements can easily be used by bone remodeling cells for reconstruction of damaged parts of bones [156, 514517]. A possibility to be injected (a minimally invasive technique), a low setting temperature, an adequate stiffness, an easy shaping and a good adaptation to the defect geometry are the major advantages of calcium orthophosphate cements and concretes, when compared to the prefabricated bulk bioceramics and porous scaffolds. 
Sergey V. Dorozhkin / BIO 2011, 1, 1-51 @CCAAS

Table 3. Various examples of the commercially available calcium orthophosphate-based bioceramics and biomaterials [13, 459, 461, 501-504].

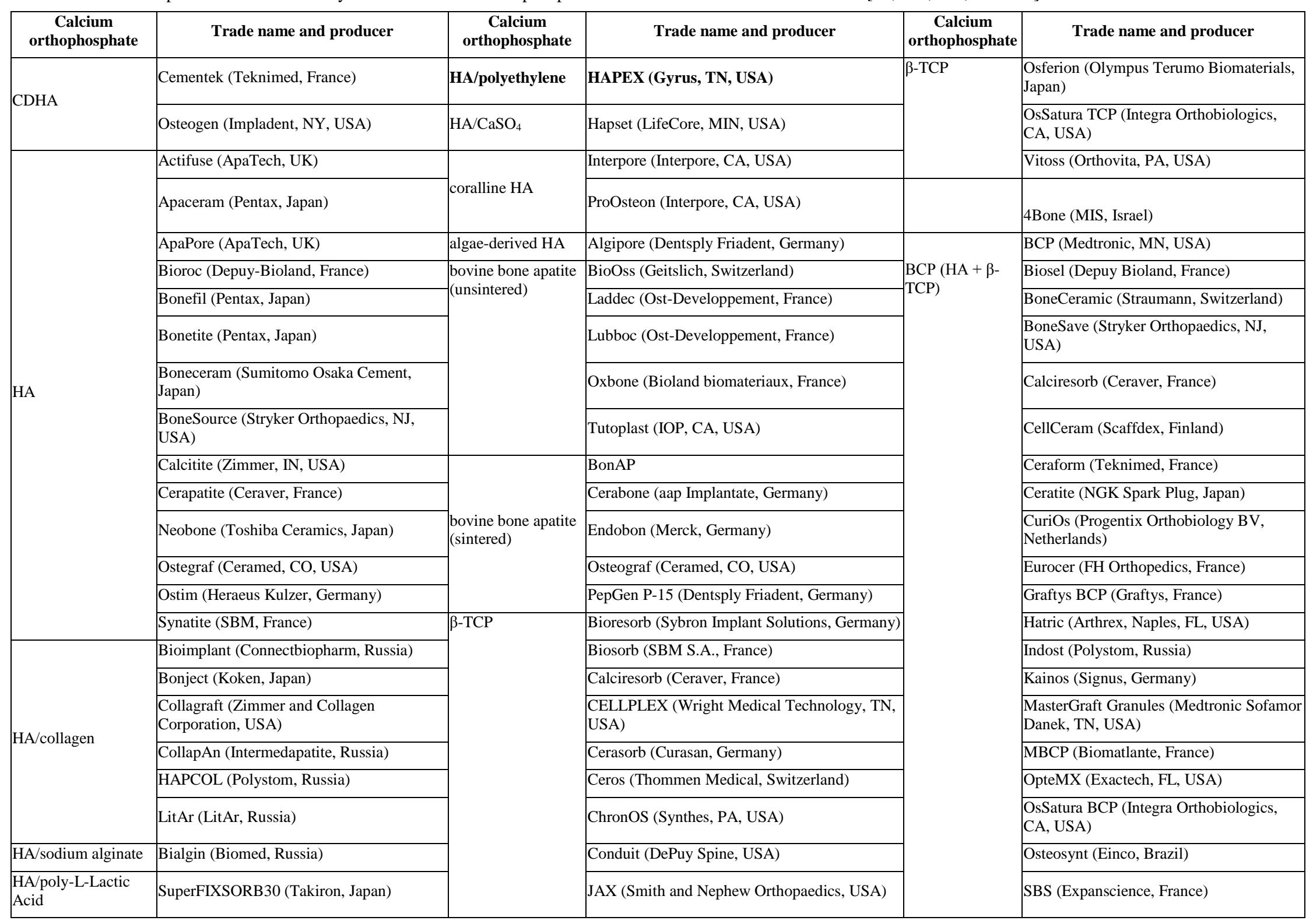


Continued Table 3. Various examples of the commercially available calcium orthophosphate-based bioceramics and biomaterials [13, 459, 461, 501-504].

\begin{tabular}{|l|l|l|l|}
\hline $\begin{array}{c}\text { Calcium } \\
\text { orthophosphate }\end{array}$ & \multicolumn{1}{|c|}{ Trade name and producer } & \multicolumn{1}{c|}{ Calcium orthophosphate } & \multicolumn{1}{|c|}{ Trade name and producer } \\
\hline \multirow{3}{*}{$\mathrm{BCP}(\mathrm{HA}+\beta-\mathrm{TCP})$} & TCH (Kasios, France) & BCP/fibrin & TricOS (Baxter BioScience, France) \\
\cline { 2 - 4 } & Triosite (Zimmer, IN, USA) & BCP/silicon & FlexHA (Xomed, FL, USA) \\
\cline { 2 - 4 } & Tribone (Stryker, Europe) & FA + BCP (HA + $\beta-\mathrm{TCP})$ & FtAP (Polystom, Russia) \\
\hline BCP $(\mathrm{HA}+\alpha-\mathrm{TCP})$ & Skelite (Millennium Biologix, ON, Canada) & \multirow{2}{*}{ carbonateapatite } & Healos (Orquest, CA, USA) \\
\cline { 2 - 4 } BCP/collagen & Allograft (Zimmer, IN, USA) & & SRS (Norian, CA, USA) \\
\hline
\end{tabular}

Table 4. Specific features of the four most common forms of bone graft substitutes. The column "defect form" lists the types of defects that can be potentially filled with the listed bone graft substitute form. "Open" means that the defect has to be widely open, e.g. an open cancellous bone defect; "Defined shape" means that the defect has to have a well-defined shape, e.g. cylinder; "Closed" means that the material can be (potentially) injected into a closed defect, $e$.g. to reinforce an osteoporotic bone [2].

\begin{tabular}{|c|c|c|c|c|}
\hline Form & Defect form & Mechanical stability & Resorption / bone formation & Handling \\
\hline $\begin{array}{l}\text { Granules }(0.1-5 \mathrm{~mm} \text { in } \\
\text { diameter })\end{array}$ & Open & Negligible & Throughout the defect & $\begin{array}{l}\text { Fair (granule migration } \\
\text { during and after surgery) }\end{array}$ \\
\hline Macroporous blocks & $\begin{array}{l}\text { Open and defined } \\
\text { shape }\end{array}$ & $\begin{array}{l}\text { Fair provided there is press-fitting } \\
\text { into the defect }\end{array}$ & Throughout the defect & $\begin{array}{l}\text { Very good (problems might } \\
\text { arise to fit the block within } \\
\text { the defect) }\end{array}$ \\
\hline Cement paste & Closed & Fair & Peripheral & $\begin{array}{l}\text { Fair to good (the paste } \\
\text { might set too fast or might } \\
\text { be poorly injectable) }\end{array}$ \\
\hline Putty & Open or closed & Negligible & $\begin{array}{l}\text { Peripheral or throughout the } \\
\text { defect depending on the } \\
\text { composition }\end{array}$ & $\begin{array}{l}\text { Very good for pastes that } \\
\text { have to be mixed in the } \\
\text { operating room to excellent } \\
\text { for ready-mixed pastes (the } \\
\text { paste might be poorly- } \\
\text { injectable) }\end{array}$ \\
\hline
\end{tabular}




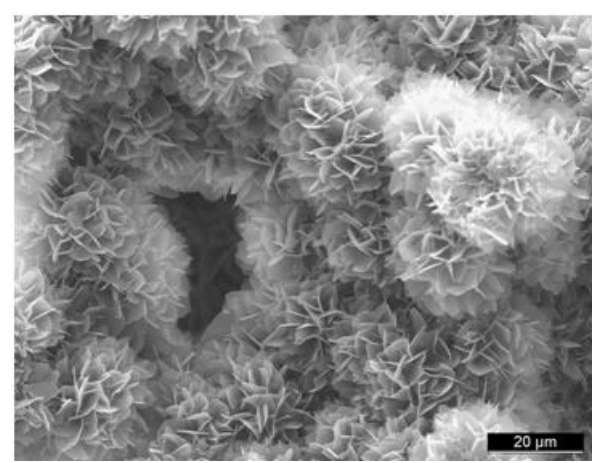

Fig. 9. A typical microstructure of calcium orthophosphate cement after hardening. The mechanical stability is provided by the physical entanglement of crystals. Reprinted from Ref. [2] with permission.

Table 5. Various techniques to deposit bioresorbable coatings of calcium orthophosphates on metal implants [538, 539].

\begin{tabular}{|c|c|c|c|}
\hline Technique & Thickness & Advantages & Disadvantages \\
\hline Thermal spraying & $30-200 \mu \mathrm{m}$ & High deposition rates; low cost & $\begin{array}{l}\text { Line of sight technique; high } \\
\text { temperatures induce decomposition; } \\
\text { rapid cooling produces amorphous } \\
\text { coatings }\end{array}$ \\
\hline Sputter coating & $0.5-3 \mu \mathrm{m}$ & $\begin{array}{l}\text { Uniform coating thickness on } \\
\text { flat substrates; dense coating }\end{array}$ & $\begin{array}{l}\text { Line of sight technique; expensive; } \\
\text { time consuming; produces } \\
\text { amorphous coatings }\end{array}$ \\
\hline $\begin{array}{l}\text { Pulsed laser } \\
\text { deposition }\end{array}$ & $0.05-5 \mu \mathrm{m}$ & $\begin{array}{l}\text { Coating by crystalline and } \\
\text { amorphous phases; dense and } \\
\text { porous coating }\end{array}$ & Line of sight technique \\
\hline $\begin{array}{l}\text { Dynamic mixing } \\
\text { method }\end{array}$ & $\begin{array}{l}0.05-1.3 \\
\mu \mathrm{m}\end{array}$ & High adhesive strength & $\begin{array}{l}\text { Line of sight technique; expensive; } \\
\text { produces amorphous coatings }\end{array}$ \\
\hline Dip coating & $\begin{array}{l}0.05-0.5 \\
\mathrm{~mm}\end{array}$ & $\begin{array}{l}\text { Inexpensive; coatings applied } \\
\text { quickly; can coat complex } \\
\text { substrates }\end{array}$ & $\begin{array}{l}\text { Requires high sintering temperatures; } \\
\text { thermal expansion mismatch }\end{array}$ \\
\hline Sol-gel technique & $<1 \mu \mathrm{m}$ & $\begin{array}{l}\text { Can coat complex shapes; low } \\
\text { processing temperatures; } \\
\text { relatively cheap as coatings are } \\
\text { very thin }\end{array}$ & $\begin{array}{l}\text { Some processes require controlled } \\
\text { atmosphere processing; expensive } \\
\text { raw materials }\end{array}$ \\
\hline $\begin{array}{l}\text { Electrophoretic } \\
\text { deposition }\end{array}$ & $\begin{array}{l}0.1-2.0 \\
\mathrm{~mm}\end{array}$ & $\begin{array}{l}\text { Uniform coating thickness; rapid } \\
\text { deposition rates; can coat } \\
\text { complex substrates }\end{array}$ & $\begin{array}{l}\text { Difficult to produce crack-free } \\
\text { coatings; requires high sintering } \\
\text { temperatures }\end{array}$ \\
\hline Biomimetic coating & $<30 \mu \mathrm{m}$ & $\begin{array}{l}\text { Low processing temperatures; } \\
\text { can form bonelike apatite; can }\end{array}$ & $\begin{array}{l}\text { Time consuming; requires } \\
\text { replenishment and a pH constancy of }\end{array}$ \\
\hline
\end{tabular}




\begin{tabular}{|l|l|l|l|} 
& & $\begin{array}{l}\text { coat complex shapes; can } \\
\text { incorporate bone growth } \\
\text { stimulating factors }\end{array}$ & simulated body fluid \\
\hline $\begin{array}{l}\text { Hot isostatic } \\
\text { pressing }\end{array}$ & $0.2-2.0 \mu \mathrm{m}$ & Produces dense coatings & $\begin{array}{l}\text { Cannot coat complex substrates; high } \\
\text { temperature required; thermal } \\
\text { expansion mismatch; elastic property } \\
\text { differences; expensive; } \\
\text { removal/interaction of encapsulation } \\
\text { material }\end{array}$ \\
\hline $\begin{array}{l}\text { Electrochemical } \\
\text { deposition }\end{array}$ & $\begin{array}{l}0.05-0.5 \\
\mathrm{~mm}\end{array}$ & $\begin{array}{l}\text { Uniform coating thickness; rapid } \\
\text { deposition rates; can coat } \\
\text { complex substrates; moderate } \\
\text { temperature, low cost }\end{array}$ & $\begin{array}{l}\text { The coating/substrate bonding is not } \\
\text { strong enough }\end{array}$ \\
\hline
\end{tabular}

5.2. Coatings For many years, the clinical application of calcium orthophosphate-based bioceramics has been largely limited to non-load bearing parts of the skeleton due to their inferior mechanical properties. One of the major innovations in the last $\sim 30$ years has been to coat mechanically strong bioinert and/or biotolerant prostheses by calcium orthophosphates [525-527]. For example, metallic implants are encountered in endoprostheses (total hip joint replacements) and artificial teeth sockets. The requirement for a sufficient mechanical stability necessitates the use of a metallic body for such devices. As metals do not undergo bone bonding, i.e., do not form a mechanically stable link between the implant and bone tissue, ways have been sought to improve contacts at the interface. The major way is to coat metals with calcium orthophosphate bioceramics that exhibit a bone-bonding ability between the metal and bone [194, 205, 339, 525, 528-533]. Thickness of the coatings varies from submicron dimensions to several hundreds microns (Table 5) and this parameter appears to be very important. For example, if a calcium orthophosphate coating is too thick, it is easy to break. On the contrary, if the coating is too thin, it is easy to dissolve, because resorbability of $\mathrm{HA}$, which is the second slowest to dissolve among calcium orthophosphates (Table 1), is about $15-30 \mu \mathrm{m}$ per year [534]. One should stress, that calcium orthophosphate coatings are not limited to metals only; they can be applied on carbon, bioinert ceramics and polymers as well [535]. Furthermore, multi-walled carbon nanotubes can be functionalized by deposition of calcium orthophosphate coatings [536]. The list of most important coating techniques is comprised in Table 5, while the main advantages and drawbacks of each coating technique, as well as the major properties of the deposed calcium orthophosphates, are discussed in details elsewhere [194, 240, 295, 525, 526, 537-551]. Unfortunately, none of these methods is able to provide the perfect covering because each coating always contains cracks, pores, second phases and residual stresses that reduced their durability and might lead to a partial or complete disintegration of the coating in body fluids. The biomedical aspects of osteoconductive coatings for total joint arthroplasty have been reviewed elsewhere [552].

All coatings must adhere satisfactorily to the underlying substrate irrespective of their intended function. Specifically, a mechanical stability of calcium orthophosphate coatings should be high enough to maintain their bioactive functionality after a surgical implantation. Generally, tensile adhesion testing according to standards such as ASTM C633 is the most common procedure to determine the quantitative values for calcium orthophosphate coating adhesion to the underlying metallic substrates. Furthermore, fatigue [553, 554], scratch [555] and pullout [555] testing are among the most valuable techniques to provide additional information on the mechanical behavior of calcium orthophosphate coatings [194].

In the 1980's, de Groot et al., published a paper [556] on the development of plasma-sprayed HA coatings on metallic implants. A little bit later, Furlong and Osborn [557], two leading surgeons in the orthopedics field, began implanting plasma-sprayed HA stems in patients. Coated implants combine the surface biocompatibility and bioactivity of calcium orthophosphates with the core strength of strong substrates (Fig. 10). Moreover, 
calcium orthophosphate coatings decrease a release of potentially hazardous chemicals from the core implant and shield the substrate surface from environmental attack. In the case of porous implants, calcium orthophosphate coatings enhance bone ingrowth into the pores [233]. The clinical results for calcium orthophosphate-coated implants reveal that they have much longer life times after implantation than uncoated devices and they have been found to be particularly beneficial for younger patients. Studies concluded that there was significantly less pin loosening in the HAcoated groups [558]. HA coating as a system of fixation of hip implants was found to work well in the short to medium term (8 years [559], 10 to 15.5 years [560], 10 to 17 years [561], 15 years [562], 16 years [563], 17 years [564], 19 years [565] and 15 to 21 years [566]). In 2004, a special book summarizing the studies with HAcoated implants and the "state of the art" of HA coatings in orthopedics at the close of 2002 was published [567]. Similar data for HA-coated dental implants are also available [568, 569]. Even longer-term clinical results are awaited with a great interest.

A number of factors appeared to influence the properties of calcium orthophosphate coatings. They include coating thickness (this will influence coating adhesion and fixation - the agreed optimum now seems to be within $50-100 \mu \mathrm{m}$ ), crystallinity (this affects the dissolution and biological behavior), phase and chemical purity, porosity and adhesion [526, 538]. Methods for the production of coatings and their properties are now largely standardized and, over recent years, calcium orthophosphate-coated implants have found highly successful clinical application, particularly in younger patients [520-572]. Further details on calcium orthophosphate coatings might be found in excellent reviews [573, 574].

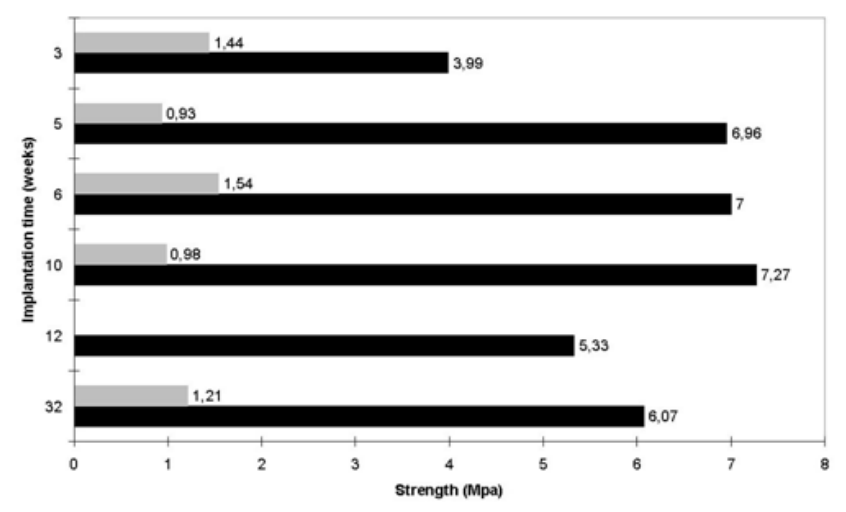

Uncoated

HA coated

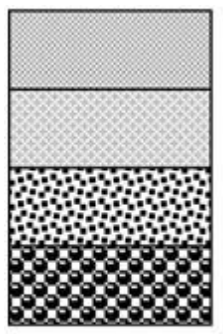

(a)

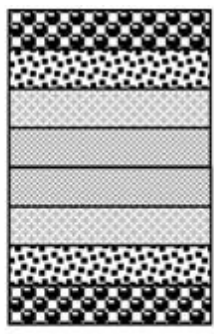

(b)

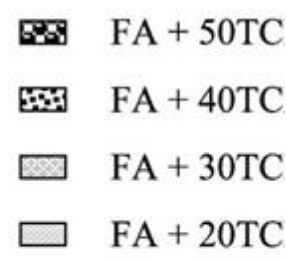

Fig. 10. Shows how a plasmasprayed HA coating on a porous titanium (dark bars) dependent on the implantation time will improve the interfacial bond strength compared to uncoated porous titanium (light bars). Reprinted from Ref. [49] with permission.
Fig. 11. A schematic diagram showing the arrangement of the FA/ $\beta$-TCP biocomposite layers. (a) A nonsymmetric functionally gradient material (FGM); (b) symmetric FGM. Reprinted from Ref. [579] with permission. 
5.3. Functionally graded bioceramics In general, functionally gradient materials (FGMs) are defined as the materials, having gradient either compositional or structural changes from their surface to the interior of the materials. The idea of FGMs allows one device to possess two different properties. One of the most important combinations for the biomedical field is that of a mechanical strength and biocompatibility. Namely, only surface properties govern a biocompatibility of the entire device. In contrast, the strongest material determines the mechanical strength of the entire device. Although, this subject belongs to the coatings section (see above), in a certain sense, metallic implants covered by calcium orthophosphates might be considered as a FGM. The surface shows excellent biocompatibility because it consists of calcium orthophosphates, while the metallic core provides the excellent mechanical strength. The gradient change from calcium orthophosphates to the metal is important, for example, from the point of thermal expansion.

Functionally graded bioceramics consisting of calcium orthophosphates only [575] have been developed [411, 482, 484, 578-587]. For example, dense sintered bodies with gradual compositional changes from $\alpha$-TCP to HA were prepared by sintering a diamond-coated HA compacts at $1280{ }^{\circ} \mathrm{C}$ under a reduced pressure, followed by heating under the atmospheric conditions [578]. The content of $\alpha$-TCP gradually decreased, while the content of HA increased with increasing depth from the surface. This functionally gradient bioceramics consisting of HA core and $\alpha$-TCP surface showed a potential value as bone-substituting biomaterials [578]. Two types of functionally gradient $\mathrm{FA} / \beta$-TCP biocomposites were prepared in another study [579]. As shown in Fig. 11, one of the graded biocomposites was in the shape of a disk and contained four different layers of about $1 \mathrm{~mm}$ thick. The other graded biocomposite was also in the shape of a disk but contained two sets of the four layers, each layer being $0.5 \mathrm{~mm}$ thick controlled by using a certain amount of the mixed powders. The final FA $/ \beta$ TCP graded structures were formed at $100 \mathrm{MPa}$ and sintered at $1300{ }^{\circ} \mathrm{C}$ for $2 \mathrm{~h}$ [579].

It is well known that a bone cross-section from cancellous to cortical bone is non-uniform in porosity and pore dimensions. Thus, in various attempts to mimic the porous structure of bones, calcium orthophosphate bioceramics with graded porosity have been fabricated [375, 411, 482, 484, 578-585, 588]. For example, graded porous calcium orthophosphate bioceramics can be produced by means of tape casting and lamination (Fig. 12a). Other manufacturing techniques, such as a compression molding process (Fig. 12b) followed by impregnation and firing, are known as well [375]. In the first method, a HA slurry was mixed with a pore former. The mixed slurry was then cast into a tape. Using the same method, different tapes with different pore former sizes were prepared individually. The different tape layers were then laminated together. Firing was then done to remove the pore formers and sinter the HA particle compacts, resulting in graded porous bioceramics [582]. This method was also used to prepare graded porous HA with a dense part (core or layer) in order to improve the mechanical strength, as dense ceramics are much stronger than porous ceramics. However, as in the pressure infiltration of mixed particles, this multiple tape casting also has the problem of poor connectivity of pores, although the pore size and the porosity are relatively easy to control. Furthermore, the lamination step also introduces additional discontinuity of the porosity on the interfaces between the stacked layers.

Since diverse biomedical applications require different configurations and shapes, the graded (or gradient) porous bioceramics can be grouped according to both the overall shape and the structural configuration [375]. The basic shapes include rectangular blocks and cylinders (or disks). For the cylindrical shape, there are configurations of dense core - porous layer, less porous core - more porous layer, dense layer - porous core and less porous layer - more porous core. For the rectangular shape, in the gradient direction i.e., the direction with varying porosity, pore size or composition, there are configurations of porous top dense bottom (same as porous bottom - dense top), porous top - dense center - porous bottom, dense top porous center - dense bottom, etc. Concerning biomedical applications, a dense core - porous layer structure is suitable for implants of a high mechanical strength and with bone ingrowth for stabilization, whereas a less porous layer - more porous core configuration can be used for drug delivery systems. Furthermore, a porous top - dense bottom structure can be shaped into implants of articulate surfaces for wear resistance and with porous ends for bone ingrowth fixation; while a dense top - porous center - dense bottom arrangement mimics the structure of head skull. Further details on bioceramics with graded porosity might be found in literature [375]. 


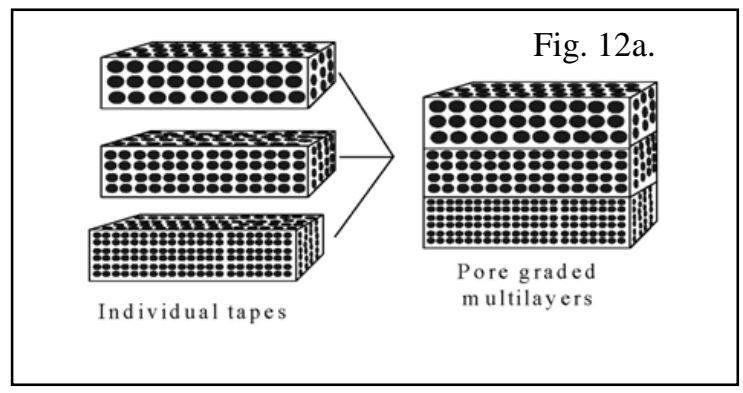

Fig. 12. Schematic illustrations of fabrication of pore-graded bioceramics: a - lamination of individual tapes, manufactured by tape casting; $b$ - a compression molding process. Reprinted from Ref. [375] with permission.

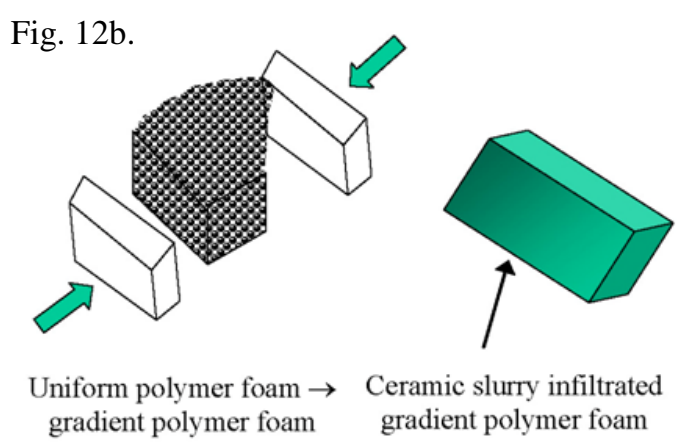

\section{Biological properties and in vivo behavior}

The most important differences between bioactive bioceramics and all other implanted materials are: inclusion in the metabolic processes of the organism; adaptation of either surface or the entire material to the biomedium; integration of a bioactive implant with bone tissues at the molecular level or the complete replacement of a resorbable bioceramics by healthy bone tissues. All of the enumerated processes are related to the effect of an organism on the implant. Nevertheless, another aspect of implantation is also important - the effect of the implant on the organism. For example, using of bone implants from corpses or animals, even after they have been treated in various ways, provokes a substantially negative immune reactions in the organism, which substantially limits the application of such implants. In this connection, it is useful to dwell on the biological properties of bioceramic implants, particularly those of calcium orthophosphates, which in the course of time may be resorbed completely [589].

6.1. Interaction with surrounding tissues and the host responses An interaction between an implant and surrounding tissues is a dynamic process. Water, dissolved ions, biomolecules and cells surround the implant surface during initial few seconds after the implantation. It has been accepted that no foreign material placed within a living body is completely compatible. The only substances that conform completely are those manufactured by the body itself (autogenous), while any other substance, which is 
such cases, thickness of the layer of fibrous tissue separating the material from other tissues of an organism can serve as a measure of bioinertness. Generally, both bioactivity and bioresorbability phenomena are fine examples of chemical reactivity and calcium orthophosphates (both non-substituted and ionsubstituted ones) fall into these two categories of bioceramics [4-7, 39, 40, 45, 49-54, 77, 531, 589-591]. A bioactive material will dissolve slightly but promote formation of a surface layer of biological apatite before interfacing directly with the tissue at the atomic level, that result in formation of a direct chemical bonds to bones. Such an implant provides a good stabilization for materials that are subject to mechanical loading. A bioresorbable material will dissolve over time (regardless of the mechanism leading to the material removal) and allow a newly formed tissue to grow into any surface irregularities but may not necessarily interface directly with the material. Consequently, the functions of bioresorbable materials are to participate in dynamic processes of formation and re-absorption occurring in bone tissues; thus, bioresorbable materials are used as scaffolds or filling spacers allowing to the tissues their infiltration and substitution [50, 194, 295, 593-595].

Interestingly a distinction between the bioactive and bioresorbable bioceramics might be associated with a structural factor only. For example, bioceramics made from non-porous, dense and highly crystalline HA behaves as a bioinert (but a bioactive) material and is retained in an organism for at least $5-7$ years without noticeable changes (Fig. 2 bottom), while a highly porous bioceramics of the same composition can be resorbed approximately within a year. Furthermore, submicron-sized HA powders are biodegraded even faster than the highly porous HA scaffolds. Other examples of bioresorbable materials include porous bioceramic scaffolds made of BCP (which is an intimate mixture of either $\beta$-TCP + HA [111-126] or $\alpha$-TCP + HA [8-12]) or bone grafts (dense or porous) made of CDHA [152], TCP [411, 596, 597] and/or ACP [462, 598]. One must stress that recently the concepts of bioactive and bioresorbable materials have converged and bioactive materials are made bioresorbable, while bioresorbable materials are made bioactive [599].

Although in certain in vivo experiments an inflammatory reaction was observed after implantation of calcium orthophosphate bioceramics [600-602], the general conclusion on using calcium orthophosphates with $\mathrm{Ca} / \mathrm{P}$ ionic ratio within $1.0-1.7$ is that all types of implants (bioceramics of various porosities and structures, powders or granules) are not only nontoxic but also induce neither inflammatory nor foreign-body reactions [603]. The biological response to implanted calcium orthophosphates follows a similar cascade observed in fracture healing. This cascade includes a hematoma formation, inflammation, neovascularization, osteoclastic resorption and a new bone formation. An intermediate layer of fibrous tissue between the implants and bones has been never detected. Furthermore, calcium orthophosphate implants display the ability to directly bond to bones [3-7, 39, 43, 49-56, 58, 525, 589]. For further details, the interested readers are referred to a good review on cellular perspectives of bioceramic scaffolds for bone tissue engineering [408].

One should note that the aforementioned rare cases of the inflammatory reactions to calcium orthophosphate bioceramics were caused by "other" reasons. For example, a high rate of wound inflammation occurred when highly porous HA was used. In that particular case, the inflammation was explained by sharp implant edges, which irritated surrounding soft tissues [601]. Another reason for inflammation produced by porous HA could be due to micro movements of the implants, leading to simultaneous disruption of a large number of microvessels, which grow into the pores of the bioceramics. This would immediately produce an inflammatory reaction. Additionally, problems could arise in clinical tests connected with migration of granules used for alveolar ridge augmentation, because it might be difficult to achieve a mechanical stability of implants at the implantation sites [601].

6.2. Osteoinduction It was generally considered that any type of synthetic bioceramics alone possessed neither osteogenic [604] nor osteoinductive [605] properties and demonstrated a minimal immediate structural support. When attached to healthy bones, an osteoid [607] is produced directly onto the surfaces of bioceramics in absence of a soft tissue interface. Consequently, the osteoid is mineralized and the resulting new bone undergoes remodeling [606]. However, several reports have already shown osteoinductive properties of certain types of calcium orthophosphate bioceramics [177, 459, 504, 608-621]. Namely, bone formation was found to occur in dog muscle inside porous calcium orthophosphates with surface microporosity, while bone was not observed on the surface of dense bioceramics [616]. Furthermore, implantation of porous $\beta$-TCP bioceramics appeared to induce bone formation in soft tissues of dogs, while no bone formation was detected in any $\alpha$-TCP implants [613]. More to the point, titanium implants coated by a microporous layer of OCP were found to induce ectopic bone formation in goat muscles, while a smooth layer of carbonated apatite on the same implants was not able to induce bone formation there $[619,620]$. 
Although the underlying mechanism(s) leading to bone induction by synthetic materials remains largely unknown, the dissolution/precipitation behavior of calcium orthophosphates [532], as well as their microporosity [621-623], chemistry [621], the specific surface area [623], as well as surface topography and geometry have been pointed out as the relevant parameters. A positive effect of increased microporosity on the ectopic bone formation could be direct and indirect. Firstly, an increased microporosity is directly related to the changes in surface topography, i.e. increases a surface roughness, which might affect the cellular differentiation. Secondly, an increased microporosity indirectly means a larger surface that is exposed to the body fluids leading to elevated dissolution/precipitation phenomena as compared to nonmicroporous surfaces. Furthermore, other hypotheses are available. Namely, Reddi explained the apparent osteoinductive properties as an ability of particular bioceramics to concentrate bone growth factors, which are circulating in biological fluids, and those growth factors induce bone formation [624]. Other researchers proposed a similar hypothesis that the intrinsic osteoinduction by calcium orthophosphate bioceramics is a result of adsorption of osteoinductive substances on their surface [618]. Moreover, Ripamonti [625] and Kuboki et al., [626] independently postulated that the geometry of calcium orthophosphate bioceramics is a critical parameter in bone induction. Specifically, bone induction by calcium orthophosphates was never observed on flat bioceramic surfaces. All osteoinductive cases were observed on either porous structures or structures contained well-defined concavities. What's more, bone formation was never observed on the peripheries of porous implants and was always found inside the pores or concavities, aligning the surface [194]. Some researchers speculated that a low oxygen tension in the central region of implants might provoke a dedifferentiation of pericytes from blood micro-vessels into osteoblasts [627]. Finally but yet importantly, both nano-structured rough surfaces and a surface charge on implants were found to cause an asymmetrical division of the stem cells into osteoblasts, which is important for osteoinduction [622].

6.3. Biodegradation Shortly after implantation, a healing process is initiated by compositional changes of the surrounding bio-fluids and adsorption of biomolecules. Following this, various types of cells reach the bioceramic surface and the adsorbed layer dictates the ways the cells respond. Further, a biodegradation of the implanted bioceramics begins. This process can occur by either physicochemical dissolution with a possibility of phase transformations or cellular activity (so called, bioresorption), as well as by a combination of both processes. Dissolution is a physical chemistry process, which is controlled by some factors, such as solubility of the implant matrix (Table 1), surface area to volume ratio, local acidity, fluid convection and temperature. For HA, the dissolution process in acids has been described by a sequence of four successive chemical equations (7.1) - (7.4) [628, 629].

With few exceptions, dissolution rates of calcium orthophosphates are inversely proportional to the $\mathrm{Ca} / \mathrm{P}$ ratio, phase purity and crystalline size, as well as it is directly related to the porosity and surface area. Phase transformations might occur with OCP, DCPA, DCPD, $\alpha$-TCP, $\beta$-TCP and ACP because they are unstable in aqueous environment under the physiological conditions. Bioresorption is a biological process mediated by cells (mainly, osteoclasts and, in a lesser extent, macrophages) [630-632]. It depends on the response of cells to their environment. Osteoclasts attach firmly to the implant and dissolve calcium orthophosphates by secreting an enzyme carbonic anhydrase or any other acid, leading to a local $\mathrm{pH}$ drop to $\sim 4-5$ [633]. Furthermore, small particles of calcium orthophosphate can also be phagocyotosed by osteoclasts, i.e. they are incorporated into cytoplasm and thereafter dissolved by acid attack and/or enzymatic processes. In any case, biodegradation of calcium orthophosphates is a combination of various nonequilibrium processes, occurring simultaneously and/or in competition with each other.

Usually an in vitro biodegradation of calcium orthophosphate bioceramics is estimated by suspending the material in a slightly acidic $(\mathrm{pH} \sim 5)$ buffer and monitoring the release of $\mathrm{Ca}^{2+}$ ions with time. The acidic buffer, to some extent, mimics the acidic environment during osteoclastic activity. In one study, an in vivo behavior of porous $\beta$-TCP bioceramics prepared from rod-shaped particles and that prepared from non-rodshaped particles in the rabbit femur was compared. Although the porosities of both types of $\beta$-TCP bioceramics were almost the same, a more active osteogenesis was preserved in the region where rodshaped bioceramics was implanted [634]. This result implied that the microstructure affected the activity of bone cells and subsequent bone replacement.

The experimental results demonstrated that both the dissolution kinetics and in vivo biodegradation of biologically relevant calcium orthophosphates proceed in the following decreasing order: $\beta$-TCP $>$ bovine bone apatite (unsintered) $>$ bovine bone apatite (sintered) $>$ coralline HA > HA. In the case of BCP bioceramics, the biodegradation kinetics depends on the HA/TCP ratio: 
the higher the ratio, the lower the degradation rate. Similarly, in vivo degradation rate of biphasic TCP $(\alpha-$ TCP $+\beta$-TCP) bioceramics appeared to be lower than that of $\alpha$-TCP and higher than that of $\beta$-TCP bioceramics, respectively [138]. Furthermore, incorporation of doping ions can either increase (e.g., $\mathrm{CO}_{3}{ }^{2-}, \mathrm{Mg}^{2+}$ or $\mathrm{Sr}^{2+}$ ) or decrease (e.g., $\mathrm{F}^{-}$) the solubility (therefore, biodegradability) of CDHA and HA. Contrarily to apatites, solubility of $\beta$-TCP is decreased by incorporation of either $\mathrm{Mg}^{2+}$ or $\mathrm{Zn}^{2+}$ ions [459]. Here one should remind that ion-substituted calcium orthophosphates are not considered in this review and the interested readers are advised to read the original publications [8-38].

6.4. Bioactivity Bioactive materials interact with surrounding bone generally resulting in formation of a chemical bond to this tissue (bone bonding). The bioactivity phenomenon is determined by both chemical factors, such as crystal phases and molecular structures of a biomaterial, and physical factors, such as surface roughness and porosity. Currently, it is agreed that the newly formed bone bonds directly to biomaterials through a carbonated CDHA layer precipitating at the bone/biomaterial interface. Strange enough but a careful seeking in the literature resulted in just a few publications $[459,538,635,636]$, where the bioactivity mechanism of calcium orthophosphates was briefly described. For example, the chemical changes occurring after exposure of a synthetic HA bioceramics to both in vivo (implantation in human) and in vitro (cell culture) conditions were studied. A small amount of HA was phagocytozed but the major remaining part behaved as a secondary nucleator as evidenced by the appearance of a newly formed mineral [635]. In vivo, a cellular activity (e.g., of macrophages or osteoclasts) associated with an acidic environment were found to result in partial dissolution of calcium orthophosphates, causing liberation of calcium and orthophosphate ions to the microenvironment. The liberated ions increased a local supersaturation degree of the surrounding biologic fluids, causing precipitation of nano-sized crystals of biological apatite with simultaneous incorporating of various ions presented in the fluids. Infrared spectroscopic analyses demonstrated that these nanosized crystals were intimately associated with bioorganic components (probably proteins), which might also have originated from the biologic fluids, such as serum [459].

One should better rely on the bioactivity mechanism of other biomaterials, particularly of bioactive glasses the concept introduced by Prof. Larry L. Hench [49-52]. The bonding mechanism of bioactive glasses to living tissues involves a sequence of 11 successive reaction steps. The initial 5 steps occurred on the surface of bioactive glasses are "chemistry" only, while the remaining 6 steps belong to "biology" because the latter include colonization by osteoblasts, followed by proliferation and differentiation of the cells to form a new bone that had a mechanically strong bond to the implant surface (Fig. 13). Therefore, in the case of bioactive glasses the border between "dead" and "alive" is postulated between stages 5 and 6 . According to Hench, all bioactive materials "form a bone-like apatite layer on their surfaces in the living body and bond to bone through this apatite layer. The formation of bonelike apatite on artificial material is induced by functional groups, such as $\mathrm{Si}-\mathrm{OH}$ (in the case of biological glasses), $\mathrm{Ti}-\mathrm{OH}, \mathrm{Zr}-\mathrm{OH}, \mathrm{Nb}-\mathrm{OH}, \mathrm{Ta}-\mathrm{OH},-\mathrm{COOH}$ and $-\mathrm{H}_{2} \mathrm{PO}_{4}$ (in the case of other materials). These groups have specific structures revealing negatively charge and induce apatite formation via formations of an amorphous calcium compound, e.g., calcium silicate, calcium titanate and ACP" [49-52].

To extend the subject, it is important to refer to another set of 11 successive reaction steps for bonding mechanism of unspecified bioceramics, developed by Prof. Paul Ducheyne (Fig. 14) [58]. One can see that the Ducheyne's model is rather similar to that proposed by Hench; however, there are noticeable differences between them. For example, Ducheyne mentions on ion exchange and structural rearrangement at the bioceramic/tissue interface (stage 3), as well as on interdiffusion from the surface boundary layer into bioceramics (stage 4) and deposition with integration into the bioceramics (stage 7), which are absent in the Hench's model. On the other hand, Hench describes six biological stages (stages $6-11$ ), while Ducheyne describes only four ones (stages $8-11$ ). Both models have been developed almost 2 decades ago and, to the best of my knowledge, remain unchanged since then. Presumably, both approaches have pro et contra of their own and, obviously, should be updated and/or revised. Furthermore, in literature there are at least two other descriptions of the biological and cellular events occurring at the bone/implant interface [637, 638]; however, they include lesser number of stages. Recently, one more hypothesis has been proposed (Fig. 15). For the first time, it describes reasonable surface transformations, happening with calcium orthophosphate bioceramics (in this case, HA) shortly after the implantation [636].

An important study on formation of calcium orthophosphate precipitates on various types of bioceramic surfaces in both simulated body fluid (SBF) and rabbit muscle sites was performed [639]. The 
bioceramics were sintered porous solids, including bioglass, glass-ceramics, $\alpha$-TCP, $\beta$-TCP and HA. An ability to induce calcium orthophosphate precipitation was compared among these types of bioceramics. The following conclusions were made: (1) OCP formation ubiquitously occurred on all types of bioceramic surfaces both in vitro and in vivo, except on $\beta$-TCP. (2) Apatite formation did not occur on every type of bioceramic surface; it was less likely to occur on the surfaces of HA and $\alpha$-TCP. (3) Precipitation of calcium orthophosphates on the bioceramic surfaces was more difficult in vivo than in vitro. (4) Differences in calcium orthophosphate precipitation among the bioceramic surfaces were less noticeable in vitro than that in vivo. (5) $\beta$-TCP bioceramics showed a poor ability of calcium orthophosphate precipitation both in vitro and in vivo [639]. These findings clearly revealed that apatite formation in the physiological environments could not be confirmed as the common feature of bioceramics.
Nevertheless, for want of anything better, currently the bioactivity mechanism of calcium orthophosphate bioceramics could be described by a reasonable combination of Figs. $10-12$, e.g., by updating the Ducheyne's and Hench's models by 3 initial stages taken from Fig. 15.

Interestingly bioactivity of HA bioceramics might be enhanced by a high-energy ion irradiation [640]. The effect was attributed to formation of a unique 3D macroporous apatite layer of decreased crystallinity and crystal size on the irradiated surfaces. To conclude this topic, the atomic and molecular phenomena occurring at the bioceramic surface in aqueous solutions and their effects on the relevant reaction pathways of cells and tissues must be elucidated in more details. However, further investigation of this topic requires a careful analysis of the available experimental data, which is beyond the scope of this review.
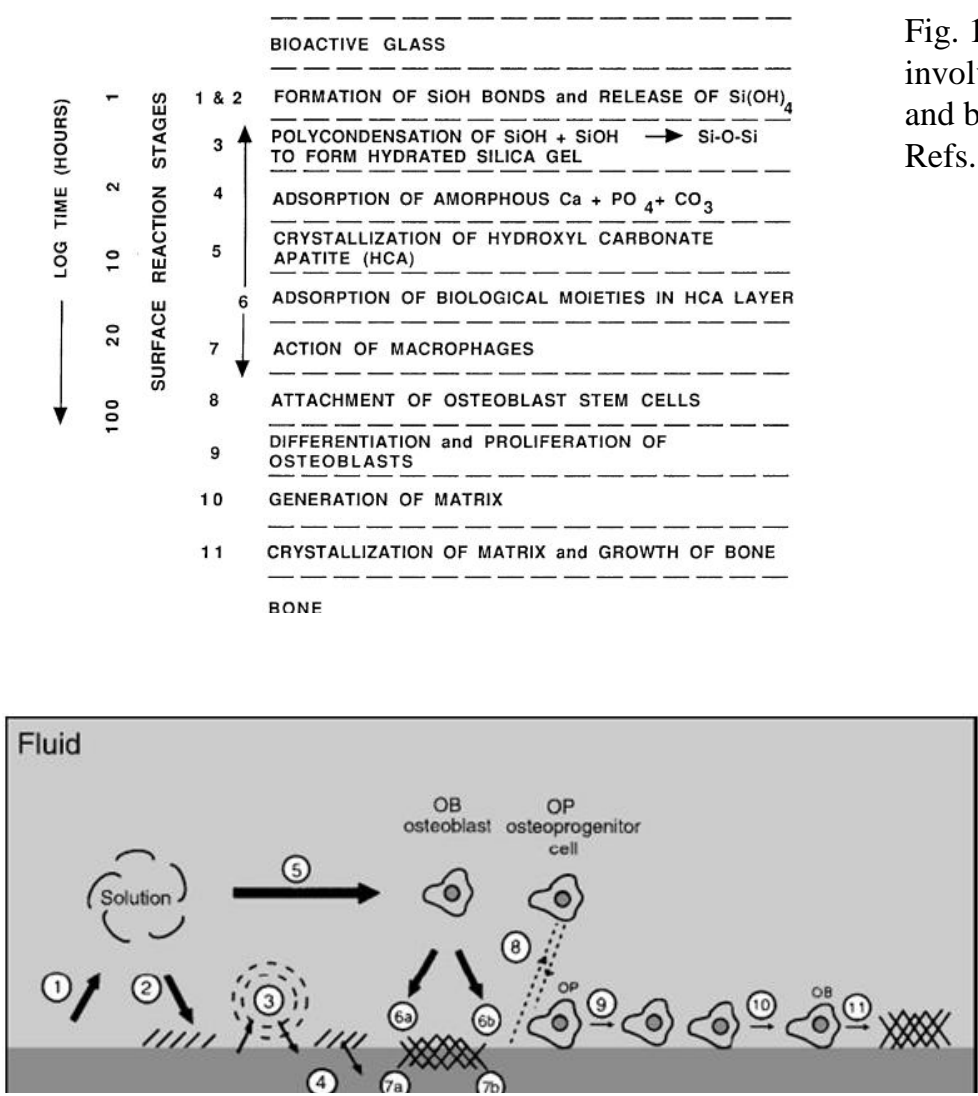

Fig. 13. A sequence of interfacial reactions involved in forming a bond between tissue and bioactive ceramics. Reprinted from Refs. [49-52] with permission.

boundary layer into the bioceramics; (5) solution-mediated effects on cellular activity; (6) deposition of either the mineral phase (a) or the organic phase (b) without integration into the bioceramic surface; (7) deposition with integration into the bioceramics; (8) chemotaxis to the bioceramic surface; (9) cell attachment and proliferation; (10) cell differentiation; (11) extracellular matrix formation. All phenomena, collectively, lead to the gradual incorporation of a bioceramic implant into developing bone tissue. Reprinted from Ref. [58] with permission.

Fig. 14. A schematic diagram representing the events, which take place at the interface between bioceramics and the surrounding biological environment: (1) dissolution of bioceramics; (2) precipitation from solution onto bioceramics; (3) ion exchange and structural rearrangement at the 


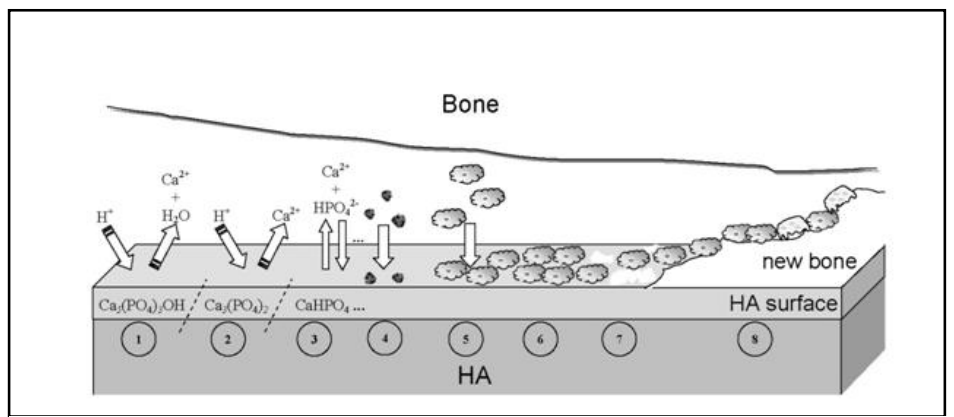

Fig. 15. A schematic diagram representing the phenomena that occur on HA surface after implantation: 1) beginning of the implant procedure, where a solubilization of the HA surface starts; 2) continuation of the solubilization of the HA surface; 3 ) the equilibrium between the physiological solutions and the

modified surface of HA has been achieved (changes in the surface composition of HA does not mean that a new phase of DCPA or DCPD forms on the surface); 4) adsorption of proteins and/or other bioorganic compounds; 5) cell adhesion; 6) cell proliferation; 7) beginning of a new bone formation; 8) new bone has been formed. Reprinted from Ref. [636] with permission.

6.5. Cellular response Fixation of an implant in the human body is a dynamic process that remodels the interface zone between the implant and living tissues at all dimensional levels, from the molecular up to the cell and tissue morphology level, and at all time scales, from the first second up to several years after implantation. Immediately following the implantation, a space filled with bio-fluids appears next to the implant surface. With time, proteins will be adsorbed at the bioceramic surface that will give rise to osteoinduction by cell proliferation and their differentiation towards bone cells, revascularisation and eventual gap closing. Ideally, a strong bond will be formed between the implant and surrounding tissues [54]. A detailed study on interfacial interactions between calcined HA and substrates have been performed recently [641], where the interested readers are referred for further details.

Osteoblasts cultured on HA bioceramics are generally reported to be completely flattened and difficult to distinguish the cytoplasmic edge from the HA surfaces after $\sim 2$ hours incubation [642]. These observations underscore an expected bioactivity of HA and make HA bioceramics well suited for bone reconstruction. Osteoblasts cultured on porous HA bioceramics appeared to exhibit a higher adhesion, an enhanced differentiation and suppressed proliferation rates when compared to the non-porous controls [643, 644]. Furthermore, formation of distinct resorption pits on HA [645] and $\beta$-TCP [634] surfaces in the presence of osteoclasts was observed. Moreover, a surface roughness of calcium orthophosphate bioceramics was reported to strongly influence the activation of mononuclear precursors to mature osteoclasts [645].

Cellular biodegradation of calcium orthophosphate bioceramics is known to depend on its phases. For example, a higher solubility of $\beta$-TCP was shown to prevent L-929 fibroblast cell adhesion, thereby leading to damage and rupture of the cells [646]. A mouse ectopic model study indicated the maximal bone growth for the $80: 20 \beta$-TCP : HA biphasic formulations preloaded with human mesenchymal stem cells when compared to other calcium orthophosphates [647]. The effects of substrate microstructure and crystallinity have been corroborated with an in vivo rabbit femur model, where rod-like crystalline $\beta$-TCP was reported to enhance osteogenesis when compared to non-rod like crystalline $\beta$-TCP [634]. Additionally, using a dog mandibular defect model, a higher bone formation on a scaffold surface coated by nanodimensional HA was observed when compared to that coated by a microdimensional HA [648]. Furthermore, recent studies revealed a stronger stress signaling response by osteoblast precursor cells in 3D scaffolds when compared to 2D surfaces [649]. Besides, variations in the physical properties of a bone substitute material (in that case, $\beta$-TCP was studied) were found to influence the inflammatory reaction and its consequences [650].

Mesenchymal stem cells are one of the most attractive cellular lines for application as bone grafts [651]. Early investigations by Okumura et al. indicated an adhesion, proliferation and differentiation, which ultimately became new bone and integrated with porous HA bioceramics [652]. Recently, Unger et al., showed a sustained co-culture of endothelial cells and osteoblasts on HA scaffolds for up to 6 weeks [653]. Furthermore, a release of factors by endothelial and osteoblast cells in co-culture supported proliferation and differentiation was suggested to ultimately result in microcapillary-like vessel formation and supported a neo-tissue growth within the scaffold [408]. More to the point, investigation of rat calvaria osteoblasts cultured on transparent HA bioceramics, as well as the analysis of osteogenic-induced human bone marrow stromal cells at different time points of culturing indicated to a good 
cytocompatibility of HA bioceramics and revealed favorable cell proliferation [368]. Positive results for other types of cells have been obtained in other studies [206, 363, 364, 367].

Interestingly HA scaffolds with marrow stromal cells in a perfused environment were reported to result in $85 \%$ increase in mean core strength, a 130\% increase in failure energy and $a \sim 355 \%$ increase in post-failure strength. The increase in mineral quantity and promotion of the uniform mineral distribution in that study was suggested to attribute to the perfusion effect [496]. Additionally, other investigators indicated to mechanical properties increasing for other calcium orthophosphate scaffolds after induced osteogenesis [495, 498].

The dimensions, extent and interconnectivity of pores in bioceramics are also known to influence bone ingrowth, blood vessels formation and canaliculi networks [452, 453, 504]. Initial reports have estimated a minimum pore size of $\sim 50 \mu \mathrm{m}$ for blood vessel formation and a minimum pore size of $\sim 200 \mu \mathrm{m}$ for osteonal ingrowth [504]. Pore dimensions of $\sim 100 \mu \mathrm{m}$ and even $\sim 50 \mu \mathrm{m}$ [654] were reported in later studies to support bone ingrowth. Additionally, vascularization, cell migration and nutrient diffusion required for sustained cell viability and tissue function are possible if pores within the scaffolds are well interconnected. For example, an essential mean pore interconnection size of $\sim 10 \mu \mathrm{m}$ was found to be necessary to allow cell migration between the pores [655]. As such, both porosity and general architecture are critical in determining the rate of fluid transport through porous bioceramics, which, in turn, determines the rate and degree of bone ingrowth in vivo $[115,455,456,656]$.

\section{Calcium orthophosphate bioceramics in tissue engineering}

7.1. Tissue engineering All modern orthopedic implants lack three of the most critical abilities of living tissues: (i) self-repairing; (ii) maintaining of blood supply; (iii) self-modifying their structure and properties in response to external aspects such as a mechanical load [473]. Needless to mention, that bones not only possess all of these properties but, in addition, they are self-generating, hierarchical, multifunctional, nonlinear, composite and biodegradable; therefore, the ideal artificial bone grafts must possess similar properties [110].

The last decades have seen a surge in creative ideas and technologies developed to tackle the problem of repairing or replacing diseased and damaged tissues, leading to the emergence of a new field in healthcare technology now referred to as tissue engineering. This is an interdisciplinary field that exploits a combination of living cells, engineering materials and suitable biochemical factors in a variety of ways to improve, replace, restore, maintain or enhance living tissues and whole organs [657, 658]. However, as 2 of 3 major components (namely, cells and biochemical factors) of the tissue engineering subject appear to be far beyond the scope of this review, the topic of tissue engineering is narrowed down to the engineering materials prepared from calcium orthophosphate bioceramics only.

Regeneration, rather than a repair, is the central goal of any tissue engineering strategy [659]. Thus, tissue engineering has a potential to create tissues and organs de novo. This field of science [661] started more than two decades ago $[662,663]$ and a famous review article by Langer and Vacanti [664] has greatly contributed to the promotion of tissue engineering research worldwide. The field of tissue engineering, particularly when applied to bone substitutes where tissues often function in a mechanically demanding environment [665], requires a collaboration of excellence in cell and molecular biology, biochemistry, material sciences, bioengineering and clinical research. For the success, it is necessary that researchers with expertise in one area have an appreciation of the knowledge and challenges of the other areas. However, since the technical, regulatory and commercial challenges might be substantial, the introduction of new products is likely to be slow [660].

Nowadays tissue engineering is at full research potential due to the following key advantages: (i) the solutions it provides are long-term, much safer than other options and cost-effective as well; (ii) the need for a donor tissue is minimal, which eliminates the immunosuppression problems; (iii) the presence of residual foreign material is eliminated as well.

7.2. Scaffolds and their properties It would be very convenient to both patients and physicians if devastated tissues or organs of patients can be regenerated by simple cell injections to the target sites but such cases are rare. The majority of large-sized tissues and organs with distinct 3D form require a support for their formation from cells. The support is called scaffold [666], template and/or artificial extracellular matrix $[158,159,422,662,665,667-670]$. The major function of scaffolds is similar to that of the natural extracellular matrix that assists proliferation, differentiation and biosynthesis of cells. In addition, scaffolds placed at the regeneration sites will prevent disturbing cells from invasion into the sites of action [671, 672]. The role of scaffolds has been perfectly described by Andrés Segovia (1893 - 1987), a Spanish classical guitarist: 
"When one puts up a building one makes an elaborate scaffold to get everything into its proper place. But when one takes the scaffold down, the building must stand by itself with no trace of the means by which it was erected. That is how a musician should work."

The idea behind tissue engineering is to create or engineer autografts by either expanding autologous cells in vitro guided by a scaffold or implanting an acellular template in vivo and allowing the patient's cells to repair the tissue guided by the scaffold. The first phase is the in vitro formation of a tissue construct by placing the chosen cells and scaffolds in a metabolically and mechanically supportive environment with growth media (in a bioreactor), in which the cells proliferate and elaborate extracellular matrix. It is expected that cells infiltrate into the porous matrix and consequently proliferate and differentiate therein. In the second phase, the construct is implanted in the appropriate anatomic location, where remodeling in vivo is intended to recapitulate the normal functional architecture of an organ or a tissue [673, 674]. The key processes occurring during both in vitro and in vivo phases of the tissue formation and maturation are: (1) cell proliferation, sorting and differentiation, (2) extracellular matrix production and organization, (3) biodegradation of the scaffold, (4) remodeling and potentially growth of the tissue.

Table 6. A hierarchical pore size distribution that an ideal scaffold should exhibit [12].

\begin{tabular}{|l|l|l|l|}
\hline Pore sizes of a 3D scaffold & \multicolumn{1}{|c|}{ A biochemical effect or function } & & \\
\hline \multirow{3}{*}{$<1 \mu \mathrm{m}$} & Interaction with proteins & $100-1000$ & Bone ingrowth \\
\cline { 2 - 2 } & Responsible for bioactivity & $\begin{array}{l}\text { Predominant function in } \\
\text { the mechanical strength }\end{array}$ \\
\hline \multirow{3}{*}{$1-20 \mu \mathrm{m}$} & \begin{tabular}{l} 
Type of cells attracted \\
\cline { 2 - 2 }
\end{tabular} & Cellular development & Implant functionality \\
\cline { 2 - 2 } & $\begin{array}{l}\text { Orientation and directionality of cellular } \\
\text { ingrowth }\end{array}$ & Implant shape \\
\cline { 2 - 2 } & Cellular growth & Implant esthetics \\
\hline $100-1000 \mu \mathrm{m}$ & & & \\
\hline
\end{tabular}

To achieve the goal of tissue reconstruction, the scaffolds must meet several specific requirements [158, 159, 667]. A reasonable surface roughness is necessary to facilitate cell seeding and fixation [675, 676]. A sufficient mechanical strength and stiffness are mandatory to oppose contraction forces and later for the remodeling of damaged tissues. A high porosity and an adequate pore dimensions (Tables 2 and 6) are very important to allow cell migration, vascularization, as well as a diffusion of nutrients [384]. Namely, scaffolds should have a network of interconnected pores where more than $\sim 60 \%$ of the pores should have a size ranging from $\sim 150 \mu \mathrm{m}$ to $\sim 400 \mu \mathrm{m}$ and at least $\sim 20 \%$ should be smaller than $\sim 20 \mu \mathrm{m}[12,92,384,394,395$, 452-459, 504, 677-684]. Scaffolds must be manufactured from the materials with controlled biodegradability and/or bioresorbability, such as calcium orthophosphate bioceramics, so that a new bone will eventually replace the scaffold [685]. Furthermore, the resorption rate has to coincide as much as possible with the rate of bone formation (i.e., between a few months and about 2 years) [686]. This means that while cells are fabricating their own natural matrix structure around themselves, the scaffold is able to provide a structural integrity within the body and eventually it will break down leaving the newly formed tissue that will take over the mechanical load. Besides, scaffolds should be easily fabricated into a variety of shapes and sizes [687] and be malleable to fit irregularly shaped defects. In many cases, ease of processability, such as an easiness of conformation, and injectability, such as self-setting calcium orthophosphate formulations possess, can determine the choice of a certain biomaterial. Finally, sterilization with no loss of properties is a crucial step in scaffold production at both a laboratory and an industrial level [665]. In conclusion, since ions of calcium and orthophosphate are known to regulate bone metabolism, calcium orthophosphates appear to be among the few bone graft substitute materials, which can be considered as a drug [2].

Many fabrication techniques are available to produce porous calcium orthophosphate scaffolds (Table 2) with varying architectural features (for details, see sections 3.3. Forming and shaping and 4.4. Porosity). In order to achieve the desired properties at minimum expenses, the production process should be optimized [688]. With the advent of tissue engineering, the search is on for the ultimate option - a "tissue engineered bone substitute", consisting of a synthetic calcium orthophosphate scaffold impregnated with cells and growth factors. Fig. 
16 schematically depicts a possible fabrication process of such item that, afterwards, will be implanted into a living organism to induce bone regeneration $[43,56]$.

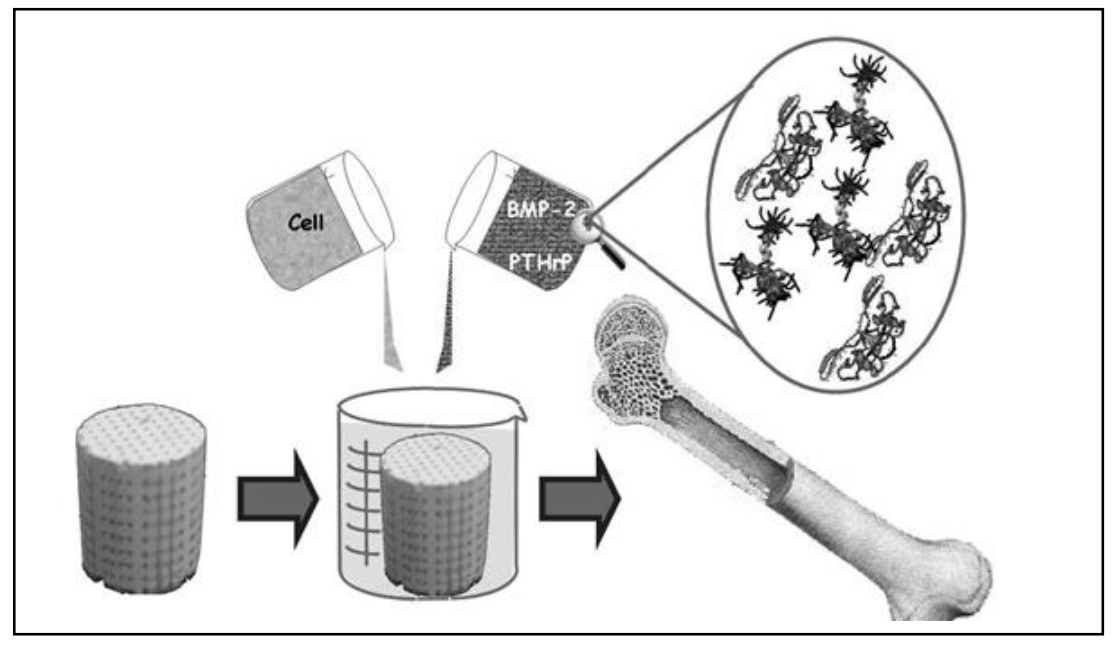

Fig. 16. A schematic view of a third generation biomaterial, in which porous calcium orthophosphate bioceramics acts as a scaffold or a template for cells, growth factors, etc. Reprinted from Refs. [43, 56] with permission.

From the structural perspectives, a degree of scaffold porosity is responsible for regulating the bioactivity of bone graft substitutes as a function of its influence on structural permeability, which controls the initial rate of bone regeneration and the local mechanical environment, which mediates the equilibrium volume of new bone within the repair site. Parameters such as pore interconnectivity, pore geometry, strut topography and strut porosity all contribute to modulate this process of osteogenesis and act synergistically to promote or screen the osteoconductive or osteoinductive potential of bone graft substitutes [455, 689, 690]. However, since bones have very different structures depending on their functions and locations, the same pore sizes and shapes may not be ideal for all potential uses. Therefore, bioceramic scaffolds of various porosities are required.

7.3. Bioceramic scaffolds from calcium orthophosphates Philosophically, the increase in life expectancy requires biological solutions to orthopedic problems, which were previously managed with mechanical solutions. Therefore, since the end of 1990 's, the biomaterials research focuses on tissue regeneration instead of tissue replacement [691]. The alternatives include use hierarchical bioactive scaffolds to engineer in vitro living cellular constructs for transplantation or use bioresorbable bioactive particulates or porous networks to activate in vivo the mechanisms of tissue regeneration $[692,693]$. Thus, the aim of calcium orthophosphate bioceramics is to prepare artificial porous scaffolds able to provide the physical and chemical cues to guide cell seeding, differentiation and assembly into 3D tissues of a newly formed bone [648, 694-700]. Particle sizes, shape and surface roughness of the scaffolds are known to affect cellular adhesion, proliferation and phenotype. Additionally, the surface energy may play a role in attracting particular proteins to the bioceramic surface and, in turn, this will affect the cells affinity to the material. More to the point, cells are exceedingly sensitive to the chemical composition and their bone-forming functions can be dependent on grain morphology of the scaffolds. For example, osteoblast functions were found to increase on nanodimensional fibers if compared to nanodimensional spheres because the former more closely approximated the shape of biological apatite in bones [701]. Besides, a significantly higher osteoblast proliferation on HA bioceramics sintered at $1200{ }^{\circ} \mathrm{C}$ as compared to that on HA bioceramics sintered at $800{ }^{\circ} \mathrm{C}$ and $1000{ }^{\circ} \mathrm{C}$ was reported [702]. Thus, to meet the tissue engineering requirements, much attention is devoted to further improvements of calcium orthophosphate bioceramics [703]. From the chemical point of view, the developments include synthesis of novel ion-substituted calcium orthophosphates [8-38]. From the material point of view, the major research topics include nanodimensional and nanocrystalline structures [704708], organic-inorganic biocomposites and hybrid biomaterials [316], fibers, whiskers and filaments [709722], micro- and nano-sized spheres and beads [722737], micro- and nano-sized tubes [738-740], porous 3D scaffolds made of ACP [462, 598], TCP [432-435], HA $[176,397,398,436,438,485,688,741-747]$ and various biphasic formulations [484, 700, 733, 748-752], structures with graded porosity $[375,411,482,484$, $578-585,588]$ and hierarchically organized ones [753, 754]. Furthermore, an addition of defects through an 
intensive milling [755, 756] or their removal by a thermal treatment [757] can be used to modify a chemical reactivity of calcium orthophosphates. Besides, more attention should be paid to a crystallographically aligned calcium orthophosphate bioceramics [758].

There are three principal therapeutic strategies for treating diseased or injured tissues in patients: (i) implantation of freshly isolated or cultured cells; (ii) implantation of tissues assembled in vitro from cells and scaffolds; (iii) in situ tissue regeneration. For cellular implantation, individual cells or small cellular aggregates from the patient or a donor are either injected into the damaged tissue directly or are combined with a degradable scaffold in vitro and then implanted. For tissue implantation, a complete 3D tissue is grown in vitro using patient or donor cells and a bioresorbable scaffold and then is implanted into the patients to replace diseased or damaged tissues. For in situ regeneration, a scaffold implanted directly into the injured tissue stimulates the body's own cells to promote local tissue repair $[657,759]$. In any case, simply trapping cells at the particular point on a surface is not enough: the cells must be encouraged to differentiate, which is impossible without the presence of suitable biochemical factors [760]. All previously mentioned clearly indicates that for the purposes of tissue engineering, calcium orthophosphate bioceramics plays an auxiliary role; namely, it acts as a suitable material to manufacture the appropriate 3D templates, substrates or scaffolds to be colonized by living cells before the successive implantation [761, 762]. The in vitro evaluation of potential calcium orthophosphate scaffolds for tissue engineering has been described elsewhere [763], while the data on the mechanical properties of calcium orthophosphate bioceramics for use in tissue engineering are also available [764, 765]. The effect of a HA-based biomaterial on gene expression in osteoblast-like cells was reported as well [766]. To conclude this part, the excellent biocompatibility of calcium orthophosphate bioceramics, its possible osteoinductivity [177, 459, 504, 608-621] and a high affinity for drugs [767], proteins and cells [786] make them very functional for the tissue engineering applications. The feasible production of scaffolds with tailored structures and properties opens up a spectacular future for calcium orthophosphates [766-774].

7.4. A clinical experience During the last decade, several groups have made steps towards a clinical application of cell-seeded calcium orthophosphate bioceramics for bone tissue engineering of humans. For example, Quarto et al., [775] were the first to report a treatment of large $(4-7 \mathrm{~cm})$ bone defects of the tibia, ulna and humerus in three patients from 16 to 41 years old, where the conventional surgical therapies had failed. The authors implanted a custom-made unresorbable porous HA scaffolds seeded with in vitro expanded autologous bone marrow stromal cells. In all three patients, radiographs and computed tomographic scans revealed abundant callus formation along the implants and good integration at the interfaces with the host bones by the second month after surgery [775]. In the same year, Vacanti et al., [776] reported the case of a man who had a traumatic avulsion of the distal phalanx of a thumb. The phalanx was replaced with a specially treated natural coral (porous HA; 500-pore ProOsteon (see Table 3)) implant that was previously seeded with in vitro expanded autologous periosteal cells. The procedure resulted in the functional restoration of a stable and biomechanically sound thumb of normal length, without the pain and complications that are usually associated with harvesting a bone graft.

Morishita et al. [777] treated a defect resulting from surgery of benign bone tumors in three patients using HA scaffolds seeded with in vitro expanded autologous bone marrow stromal cells after osteogenic differentiation of the cells. Two bone defects in a tibia and one defect in a femur were treated. Although ectopic implants in nude mice were mentioned to show the osteogenicity of the cells, details such as the percentage of the implants containing bone and at what quantities were not reported. Furthermore, cell-seeded calcium orthophosphate scaffolds were found to be superior to autograft, allograft or cell-seeded allograft in terms of bone formation at ectopic implantation sites [778]. Besides, it has been hypothesized that dental follicle cells combined with $\beta$-TCP bioceramics might become a novel therapeutic strategy to restore periodontal defects [779].

\section{Conclusions and outlook}

The available chronology of seeking for a suitable bioceramics as bone substitutes is summarized here: since the 1950's, the first aim was to use bioinert [592] bioceramics that had no reaction with living tissues. Bioinert bioceramics included inert and tolerant compounds that were designed to withstand physiological stress without stimulating any specific cellular responses. Later on, in the 1980's, the trend changed towards exactly the opposite: the idea was to implant bioceramics that reacted with the surrounding tissues by producing newly formed bone (a "responsive" bioceramics because it was able to elicit biological responses). These two stages have been referred to as 
the first and the second generations of bioceramics, respectively [780]. Currently both of them are extensively commercialized. The majority of the marketable products listed in Table 3 belong to the first and the second generations of bone substitute biomaterials. The progress of bioceramics keeps going and in current century scientists search for the third generation of bioceramics [759] that will be able to "instruct" the physiological environment toward desired biological responses (i.e., bioceramics will be able to regenerate bone tissues by stimulating specific responses at the molecular level) $[41,43,56]$. One should note that these three generations should not be interpreted as chronologically but the conceptually, since each generation represents an evolution on the requirements and properties of the biomaterials involved. This means that at present research and development is still devoted to biomaterials and bioceramics that could be considered to be of the first or the second generations according to their properties, because the second generation of bioceramics with added porosity is one of the initial approaches in developing of the third generation of bioceramics [781]. Furthermore, there is another classification of the history of biomaterials introduced by Prof. James M. Anderson. According to Anderson, within 1950 - 1975 the researchers studied bioMATERIALS, within 1975 2000 they studied BIOMATERIALS, and since 2000 the time for BIOmaterials has been coming [782]. The capital letters here emphasis the major direction of the research efforts in the complex subject of biomaterials. As bioceramics are biomaterials of the ceramic origin (see section 2. General knowledge on biomaterials and bioceramics), the Anderson's historical classification appears to be applicable to the bioceramics field as well.

The history development of bioceramics, one category of biomaterials, informs that the widespread use of biomaterials, however, experiences two major difficulties. The first is an incomplete understanding of the physical and chemical functioning of biomaterials and of the human response to these materials. Recent advances in material characterization and computer science, as well as in cell and molecular biology are expected to play a significant role in studies of biomaterials. A second difficulty is that many biomaterials do not perform as desirably as we would like. This is not surprising, since many materials used in medicine were not designed for medical purposes. It needs to be mentioned here that biomaterials are expected to perform in our body's internal environment, which is very aggressive. For example, solution $\mathrm{pH}$ of body fluids in various tissues varies in the range from 1 to 9. During daily activities, bones are subjected to a stress of $\sim 4 \mathrm{MPa}$, whereas the tendons and ligaments experience peak stresses in the range of $40-80 \mathrm{MPa}$. The mean load on a hip joint is up to three times body weight $(3000 \mathrm{~N})$ and peak load during jumping can be as high as $\sim 10$ times body weight. More importantly these stresses are repetitive and fluctuating with different activities such as standing, sitting, jogging, stretching and climbing. All of these require careful designing of biomaterials in terms of composition, shape, physical and biocompatibility properties, therefore a significant challenge is the rational design of human biomaterials based on a systematic evaluation of desired biological, chemical and engineering requirements [44].

Nevertheless, the field of biomaterials is in the midst of a revolutionary change in which the life sciences are becoming equal in importance to materials science and engineering as the foundation of the field. Simultaneously, advances in engineering (for example nanotechnology) are greatly increasing the sophistication with which biomaterials are designed and have allowed fabrication of biomaterials with increasingly complex functions [59]. Specifically, during last $\sim 40$ years, calcium orthophosphate bioceramics has become an integral and vital segment of our modern health care delivery system. In the modern fields of the third generation bioceramics (Hench) or BIOceramics (Anderson), the full potential of calcium orthophosphates has only begun to be recognized. Namely, calcium orthophosphates, which were intended as osteoconductive bioceramics in the past, stand for materials to fabricate osteoinductive implants nowadays [177, 459, 504, 608-621]. The initial steps in this direction have been already made by both fabricating BCP-based scaffolds for bone tissue engineering through the design of controlled 3D-porous structures and increasing the biological activity through development of novel ion-substituted calcium orthophosphate bioceramics [12, 461]. In the future, the composition, microstructure and molecular surface chemistry of various types of calcium orthophosphates will be tailored to match the specific biological and metabolic requirements of tissues or disease states. This new generation of calcium orthophosphate bioceramics should enhance the quality of life of millions of people, as they grow older [783]. In spite of the great progress, there is still a great potential for major advances to be made in the field of calcium orthophosphate bioceramics [5] in the following aspects.

- Improvement of the mechanical performance of existing types of bioceramics;

- Improvement in the performance of biomedical coatings in terms of their mechanical stability and ability to deliver biological agents; 
- Enhanced bioactivity in terms of gene activation;

- Development of smart biomaterials capable of combining sensing with bioactivity;

- Development of improved biomimetic composites.

At the same time, there are needs for a better understanding of the biological systems. For example, the bonding mechanism between the bone mineral and collagen remains unclear. It is also unclear whether a rapid repair elicited by the new generation of bioceramics is a result of the enhancement of mineralization per se or whether there is a more complex signaling process involving proteins in collagen. If we were able to understand the fundamentals of bone response to specific ions and the signals they activate, then we would be able to design better bioceramics for the future [5].

This review shows that the present status of research development in calcium orthophosphate bioceramics is still obviously at the starting point for the solution of new problems at the confluence of materials science, biology and medicine, concerned with the restoration of damaged functions in the human organisms. A large increase in active elderly people has dramatically raised the need for load-bearing bone graft substitutes, for example, for bone reconstruction during revision arthroplasty or for the reinforcement of osteoporotic bones. Strategies applied in the last four decades towards this goal have failed. New strategies, possibly based on self-assembling and/or nanofabrication, will thus have to be proposed and developed [784]. Furthermore, in the future it should be feasible to design a new generation of gene-activating calcium orthophosphate based scaffolds tailored for specific patients and disease states. Sometime bioactive stimuli will perhaps be used to activate genes in a preventative treatment to maintain the health of aging tissues. Currently this concept seems impossible, however we need to remember that only $\sim 40$ years ago the concept of a material that would not be rejected by living tissues also seemed impossible [599].

\section{References and Notes}

[1] Bioactivity is defined as the property of the material to develop a direct, adherent and strong bonding with bone.

[2] Bohner, M. Mater. Today 2010, 13, 24-30.

[3] Doremus, R. H. J. Mater. Sci. 1992, 27, 285-297.

[4] Vallet-Regí, M. J. Chem. Soc. Dalton Trans. 2001, 97-108.

[5] Best, S. M.; Porter, A. E.; Thian, E. S.; Huang, J. J. Eur. Ceram. Soc. 2008, 28, 1319-1327.

[6] Vallet-Regí, M. C. R. Chimie 2010, 13, 174-185.

[7] Rahaman, M. N.; Yao, A.; Bal, B. S.; Garino, J. P.; Ries, M. D. J. Am. Ceram. Soc. 2007, 90, 1965-1988.

[8] Langstaff, S. D.; Sayer, M.; Smith, T. J. N.; Pugh, S. M.; Hesp, S. A. M.; Thompson, W. T. Biomaterials 1999, 20, 1727-1741.

[9] Langstaff, S. D.; Sayer, M.; Smith, T. J. N.; Pugh, S. M. Biomaterials 2001, 22, 135-150.

[10] Sayer, M.; Stratilatov, A. D.; Reid, J. W.; Calderin, L.; Stott, M. J.; Yin, X.; MacKenzie, M.; Smith, T. J. N.; Hendry, J. A.; Langstaff, S. D. SBiomaterials 2003, 24, 369-382.

[11] Reid, J. W.; Pietak, A. M.; Sayer, M.; Dunfield, D.; Smith, T. J. N. Biomaterials 2005, 26, 2887-2897.

[12] Sanchez-Sálcedo, S.; Arcos, D.; Vallet-Regí, M. Key Eng. Mater. 2008, 377, 19-42.

[13] Ito, A.; LeGeros, R. Z. Key Eng. Mater. 2008, 377, 85-98.

[14] Ergun, C.; Webster, T. J.; Bizios, R.; Doremus, R. H. J. Biomed. Mater. Res. 2002, 59, 305-311.

[15] Webster, T. J.; Ergun, C.; Doremus, R. H.; Bizios, R. J. Biomed. Mater. Res. 2002, 59, 312-317.
[16] Kim, S. R.; Lee, J. H.; Kim, Y. T.; Riu, D. H.; Jung, S. J.; Lee, Y. J.; Chung, S. C.; Kim, Y. H. Biomaterials 2003, 24, 13891398.

[17] Patel, N.; Best, S. M.; Bonfield, W. J. Australasian Ceram. Soc. 2005, 41, 1-22.

[18] Vallet-Regí, M.; Arcos, D. J. Mater. Chem. 2005, 15, 15091516.

[19] Landi, E.; Celotti, G.; Logroscino, G.; Tampieri, A. J. Eur. Ceram. Soc. 2003, 23, 2931-2937.

[20] Gbureck, U.; Thull, R.; Barralet, J. E. J. Mater. Sci. Mater. Med. 2005, 16, 423-427.

[21] Kannan, S.; Ventura, J. M.; Ferreira, J. M. F. Chem. Mater. 2005, 17, 3065-3068.

[22] Tas, A. C.; Bhaduri S. B.; Jalota, S. Mater. Sci. Eng. C 2007, 27, 394-401.

[23] Gbureck, U.; Knappe, O.; Grover, L. M.; Barralet, J. E. Biomaterials 2005, 26, 6880-6886.

[24] Tardei, C.; Grigore, F.; Pasuk, I.; Stoleriu, S. J. Optoelectronics Adv. Mater. 2006, 8, 568-571.

[25] Pietak, A. M.; Reid, J. W.; Stott, M. J.; Sayer, M. Biomaterials 2007, 28, 4023-4032.

[26] Yao, Z. P.; Liu, W. G.; Ni, G. X. J. Clin. Rehabil. Tissue Eng. Res. 2008, 12, 7151-7154.

[27] Landi, E.; Tampieri, A.; Mattioli-Belmonte, M.; Celotti, G.; Sandri, M.; Gigante, A.; Fava, P.; Biagini, G. J. Eur. Ceram. Soc. 2006, 26, 2593-2601. 
[28] Landi, E.; Tampieri, A.; Celotti, G.; Sprio, S.; Sandri, M.; Logroscino, G. Acta Biomater. 2007, 3, 961-969.

[29] Kannan, S.; Ventura, J. M. G.; Ferreira, J. M. F. Ceram. Int. 2007, 33, 1489-1494.

[30] Kannan, S.; Rebelo, A.; Lemos, A. F.; Barba, A.; Ferreira, J. M. F. J. Eur. Ceram. Soc. 2007, 27, 2287-2294.

[31] Kannan, S.; Goetz-Neunhoeffer, F.; Neubauer, J.; Ferreira, J. M. F. J. Am. Ceram. Soc. 2008, 91, 1-12.

[32] Lafon, J. P.; Champion, E.; Bernache-Assollant, D. J. Eur. Ceram. Soc. 2008, 28, 139-147.

[33] Ren, F.; Xin, R.; Ge, X.; Leng, Y. Adv. Mater. Res. 2008, 47-50, Part 2, 1379-1382.

[34] Meejoo, S.; Pon-On, W.; Charnchai, S.; Amornsakchai, T. Adv. Mater. Res. 2008, 55-57, 689-692.

[35] Kannan, S.; Goetz-Neunhoeffer, F.; Neubauer, J.; Ferreira, J. M. F. J. Am. Ceram. Soc. 2009, 92, 1592-1595.

[36] Natasha, A. N.; Sopyan, I.; Zuraida, A. Adv. Mater. Res. 2008, 47-50, Part 2, 1185-1188.

[37] Matsumoto, N.; Yoshida, K.; Hashimoto, K.; Toda, Y. Mater. Res. Bull. 2009, 44, 1889-1894.

[38] Boanini, E.; Gazzano, M.; Bigi, A. Acta Biomater. 2010, 6, 1882-1894.

[39] Williams, D. F. The Williams dictionary of biomaterials. Liverpool University Press. Liverpool, UK, 1999; 368 pp.

[40] Williams, D. F. Biomaterials 2009, 30, 5897-5909.

[41] Bongio, M.; van den Beucken, J. J. J. P.; Leeuwenburgh, S. C. G.; Jansen, J. A. J. Mater. Chem. 2010, 20, 8747-8759.

[42] Mann, S. (Ed.), Biomimetic materials chemistry. Wiley-VCH, UK. 1996, 400 pp.

[43] Vallet-Regí, M. Key Eng. Mater. 2008, 377, 1-18.

[44] Tripathi, G.; Choudhury, P.; Basu, B. Mater. Technol. 2010, 25, 158-176.

[45] Jandt, K. D. Adv. Eng. Mater. 2007, 9, 1035-1050.

[46] Meyers, M. A.; Chen, P. Y.; Lin, A. Y. M.; Seki, Y. Prog. Mater. Sci. 2008, 53, 1-206.

[47] According to Wikipedia, the free encyclopedia: "The word

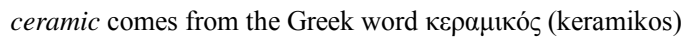
meaning pottery, which is said to derive from the Indo-European word ker, meaning heat. A ceramic is an inorganic, non-metallic solid prepared by the action of heat and subsequent cooling. Ceramic materials may have a crystalline or partly crystalline structure, or may be amorphous (e. g.; a glass). Because most common ceramics are crystalline, the definition of ceramic is often restricted to inorganic crystalline materials, as opposed to the non-crystalline glasses. Ceramic may be used as an adjective describing a material, product or process; or as a singular noun, or, more commonly, as a plural noun, ceramics." http://en.wikipedia.org/wiki/Ceramics (accessed in November 2010).

[48] Biocompatibility is the ability of a material to perform with an appropriate host response in a specific application [49-52].

[49] Hench, L. L. J. Am. Ceram. Soc. 1991, 74, 1487-1510.
[50] Cao, W.; Hench, L. L. Ceram. Int. 1996, 22, 493-507.

[51] Hench, L. L. J. Am. Ceram. Soc. 1998, 81, 1705-1728.

[52] Hench, L. L.; Day, D. E.; Höland, W.; Rheinberger, V. M. Int. J. Appl. Glass Sci. 2010, 1, 104-117.

[53] Pinchuk, N. D.; Ivanchenko, L. A. Powder Metall. Metal Ceram. 2003, 42, 357-371.

[54] Heimann, R. B. CMU J. 2002, 1, 23-46.

[55] Dorozhkin, S. V. Glass Ceram. 2007, 64, 442-447.

[56] Salinas, A. J.; Vallet-Regí, M. Z. Anorg. Allg. Chem. 2007, 633, 1762-1773.

[57] Tomoda, K.; Ariizumi, H.; Nakaji, T.; Makino, K. Colloids Surf. B 2010, 76, 226-235.

[58] Ducheyne, P.; Qiu, Q. Biomaterials 1999, 20, 2287-2303.

[59] Huebsch N.; Mooney, D. J. Nature 2009, 462, 426-432.

[60] Ring, M. E. Dentistry: an illustrated history. Harry N. Abrams, New York, USA, 1992, 320 pp.

[61] Bobbio, A. Bull. Hist. Dent. 1970, 20, 1-6.

[62] Lowenstam, H. A.; Weiner, S. On biomineralization. Oxford University Press, 1989, 324 pp.

[63] Weiner, S.; Wagner, H. D. Ann. Rev. Mater. Sci. 1998, 28, 271298.

[64] LeGeros, R. Z. Calcium phosphates in oral biology and medicine. Karger, Basel, 1991, 201 pp.

[65] Weiner, S.; Dove, P. M. An overview of biomineralization processes and the problem of the vital effect. In:

Biomineralization. Series: Reviews in Mineralogy and Geochemistry. Vol. 54. Dove, P. M.; de Yoreo, J. J.; Weiner, S.; Eds.; Mineralogical Society of America: Washington, D. C.; USA, 2003: pp. 1-29.

[66] Weiner, S.; Traub, W.; Wagner, H. D. J. Struct. Biol. 1999, 126, 241-255.

[67] Albee, F. H. Ann. Surg. 1920, 71, 32-39.

[68] Ray, R. D.; Ward, A. A.; Jr. Surg. Form. 1951, 3, 429-434.

[69] Nery, E. B.; Lynch, K. L.; Hirthe W. M.; Mueller; K. H. J. Periodontol. 1975, 46, 328-347.

[70] Denissen, H. W.; de Groot, K. J. Prosthet. Dent. 1979, 42, 551556.

[71] Blakeslee, K. C.; Condrate, R. A.; Sr. J. Am. Ceram. Soc. 1971, $54,559-563$.

[72] Garrington, G. E.; Lightbody, P. M. J. Biomed. Mater. Res. 1972, 6, 333-343.

[73] Cini, L.; Sandrolini, S.; Paltrinieri, M.; Pizzoferrato, A.; Trentani, C. La Chirurgia Degli Organi Di Movimento 1972, 60, 423-430.

[74] Rivault, M. A. Revue Francaise d'Odonto-Stomatologie 1966, 13, 1367-1402.

[75] Dumont, A.; Appel, M.; Favard, E. Annales OdontoStomatologiques 1968, 25, 231-240.

[76] Hulbert, S. F.; Young, F. A.; Mathews, R. S.; Klawitter, J. J.; Talbert, C. D.; Stelling, F. H. J. Biomed. Mater. Res. 1970, 4, 433-456. 
[77] Hench, L. L.; Splinter, R. J.; Allen, W. C.; Greenlee, T. K. J. Biomed. Mater. Res. 1971, 2, 117-141.

[78] Hulbert, S. F.; Hench, L. L.; Forbers, D.; Bowman, L. S. Ceram. Int. 1982, 8, 131-140.

[79] Hulbert, S. F.; Hench, L. L.; Forbers, D.; Bowman, L. S. History of bioceramics. In: Ceramics in Surgery. Vincenzini, P. (Ed.), Elsevier, Amsterdam, Netherlands. 1983, pp. 3-29.

[80] Jarcho, M.; Bolen, C. H.; Thomas, M. B.; Bobick, J.; Kay, J. F. Doremus, R. H. J. Mater. Sci. 1976, 11, 2027-2035.

[81] Jarcho, M.; O’Connor, J. R.; Paris, D. A. J. Dent. Res. 1977, 56, 151-156.

[82] Jarcho, M.; Salsbury, R. L.; Thomas, M. B.; Doremus, R. H. J. Mater. Sci. 1979, 14, 142-150.

[83] Jarcho, M. Clin. Orthop. Rel. Res. 1981, 157, 259-278.

[84] Rejda, B. V.; Peelen, J. G. J.; de Groot, K. J. Bioeng. 1977, 1, 93-97.

[85] de Groot, K. Biomaterials 1980, 1, 47-50.

[86] de Groot, K. (Ed.) Bioceramics of calcium phosphate. CRC Press, Boca Raton, Fl, 1983, 146 pp.

[87] Aoki, H.; Kato, K. M.; Ogiso, M.; Tabata, T. J. Dent. Eng. 1977, 18, 86-89.

[88] Kato, K.; Aoki, H.; Tabata, T.; Ogiso, M. Biomater. Med. Dev. Artif. Organs 1979, 7, 291-297.

[89] Akao, M.; Aoki, H.; Kato, K. J. Mater. Sci. 1981, 16, 809-812.

[90] Akao, M.; Aoki, H.; Kato, K.; Sato, A. J. Mater. Sci. 1982, 17, 343-346.

[91] Roy, D. M.; Linnehan, S. K. Nature 1974, 247, 220-222.

[92] Holmes, R. E. Plast. Reconstr. Surg. 1979, 63, 626-633.

[93] Elsinger, E. C.; Leal, L. J. Foot Ankle Surg. 1996, 35, 396-399.

[94] Shipman, P.; Foster, G.; Schoeninger, M. J. Archaeological Sci. 1984, 11, 307-325.

[95] LeGeros, R. Z. LeGeros, J. P. Key Eng. Mater. 2003, 240-242, 310.

[96] Oktar, F. N.; Kesenci, K.; Pişkin, E. Artificial Cells, Blood Substitutes, and Immobilization Biotechnology 1999, 27, 367 379.

[97] Rivera, E. M.; Araiza, M.; Brostow, W.; Castaño, V. M.; DíazEstrada, J. R.; Hernández, R.; Rodríguez, J. R. Mater. Lett. 1999, 41, 128-134.

[98] Lee, S. J.; Oh, S. H. Mater. Lett. 2003, 57, 4570-4574.

[99] Balazsi, C.; Weber, F.; Kover, Z.; Horvath, E.; Nemeth, C. J. Eur. Ceram. Soc. 2007, 27, 1601-1606.

[100]Murugan, R.; Ramakrishna, S. Cryst. Growth Des. 2005, 5, 111112.

[101]Ruksudjarit, A.; Pengpat, K.; Rujijanagul, G.; Tunkasiri, T. Curr. Appl. Phys. 2008, 8, 270-272.

[102] Ooi, C. Y.; Hamdi, M.; Ramesh, S. Ceram. Int. 2007, 33, 11711177.

[103]Lee, S. J.; Lee, Y. C.; Yoon, Y. S. J. Ceram. Process. Res. 2007, $8,427-430$.

[104]Oktar, F. N. Ceram. Int. 2007, 33, 1309-1314.
[105]Figueiredo, M.; Fernando, A.; Martins, G.; Freitas, J.; Judas, F.; Figueiredo, H. Ceram. Int. 2010, 36, 2383-2393.

[106]Han, F.; Wu, L. Ceram. Int. 2010, 220, 281-285.

[107]Gergely, G.; Wéber, F.; Lukács, I.; Illés, L.; Tóth, A. L.; Horváth, Z. E.; Mihály, J.; Balázsi, C. Central Eur. J. Chem. 2010, 8, 375-381.

[108]Harabi, A.; Belamri, D.; Karboua, N.; Mezahi, F. Z. Sintering of bioceramics using a modified domestic microwave oven natural hydroxyapatite sintering. J. Thermal Analysis and Calorimetry 2010, (early view).

[109]Mondal, S.; Mahata, S.; Kundu, S.; Mondal, B. Adv. Appl. Ceram. 2010, 109, 234-239.

[110]Vallet-Regí, M.; González-Calbet, J. M. Progr. Solid State Chem. 2004, 32, 1-31.

[111]Lecomte, A.; Gautier, H.; Bouler, J. M.; Gouyette, A.; Pegon, Y.; Daculsi, G.; Merle, C. J. Biomed. Mater. Res. B (Appl. Biomater.) 2008, 84B, 1-6.

[112]Tancret, F.; Bouler, J. M.; Chamousset, J.; Minois, L. M. J. Eur. Ceram. Soc. 2006, 26, 3647-3656.

[113]Bouler, J. M.; Trecant, M.; Delecrin, J.; Royer, J.; Passuti, N.; Daculsi, G. J. Biomed. Mater. Res. 1996, 32, 603-609.

[114]Kivrak, N.; Tas, A. C. J. Am. Ceram. Soc. 1998, 81, 2245-2252.

[115]Gauthier, O.; Bouler, J. M.; Aguado, E.; Pilet, P.; Daculsi, G. Biomaterials 1998, 19, 133-139.

[116] Wang, J.; Chen, W.; Li, Y.; Fan, S.; Weng, J.; Zhang, X. Biomaterials 1998, 19, 1387-1392.

[117]Daculsi, G. Biomaterials 1998, 19, 1473-1478.

[118]Daculsi, G.; Weiss, P.; Bouler, J. M.; Gauthier, O.; Millot, F.; Aguado, E. Bone 1999, 25, Suppl. 2, 59S-61S.

[119]LeGeros, R. Z. Lin, S.; Rohanizadeh, R.; Mijares, D.; LeGeros, J. P. J. Mater. Sci. Mater. Med. 2003, 14, 201-209.

[120]Daculsi, G.; Laboux, O.; Malard, O.; Weiss, P. J. Mater. Sci. Mater. Med. 2003, 14, 195-200.

[121]Dorozhkina, E. I.; Dorozhkin, S. V. Chem. Mater. 2002, 14, 4267-4272.

[122] Alam, I.; Asahina, I.; Ohmamiuda, K.; Enomoto, S. J. Biomed. Mater. Res. 2001, 54, 129-138.

[123]Daculsi, G. Adv. Sci. Technol. 2006, 49, 9-13.

[124] Tanimoto, Y.; Shibata, Y.; Murakami, A.; Miyazaki, T.; Nishiyama, N. J. Hard Tiss. Biol. 2009, 18, 71-76.

[125]Daculsi, G.; Baroth, S.; LeGeros, R. Z. Ceram. Eng. Sci. Proc. 2010, 30, 45-58.

[126]Lukić, M.; Stojanović, Z.; Škapin, S. D.; Maček-Kržmanc, M.; Mitrić, M.; Marković, S.; Uskoković, D. J. Eur. Ceram. Soc. 2011, 31, 19-27.

[127] O’Neill, W. C. Kidney Int. 2007, 72, 792-796.

[128] da Silva, R. V.; Bertran, C. A.; Kawachi, E. Y.; Camilli, J. A. J. Craniofac. Surg. 2007, 18, 281-286.

[129]Metsger, D. S.; Driskell, T. D.; Paulsrud, J. R. J. Am. Dent. Assoc. 1982, 105, 1035-1038.

[130]Reid, J. W.; Tuck, L.; Sayer, M.; Fargo, K.; Hendry, J. A. Biomaterials 2006, 27, 2916-2925.

http://ccaasmag.org/BIO 
[131] Yin, X.; Stott, M. J.; Rubio, A. Phys. Rev. B 2003, 68, 205205 (7 pages).

[132] Yin, X.; Stott, M. J. J. Chem. Phys. 2005, 122, 024709 (9 pages).

[133]Ruan, J. M.; Zou, J. P.; Zhou, J. N.; Hu, J. Z. Powder Metall. 2006, 49, 66-69.

[134] Yin, X.; Stott, M. J. J. Chem. Phys. 2006, 124, 124701 (9 pages).

[135] Kamitakahara, M.; Ohtsuki, C.; Miyazaki, T. J. Biomater. Appl. 2008, 23, 197-212.

[136]Li, Y.; Kong, F.; Weng, W. J. Biomed. Mater. Res. B (Appl. Biomater.) 2009, 89B, 508-517.

[137]Oishi, M.; Ohtsuki, C.; Kitamura, M.; Kamitakahara, M.; Ogata, S.; Miyazaki, T.; Tanihara, M. Phosphorus Res. Bull. 2004, 17, 95-100.

[138] Kamitakahara, M.; Ohtsuki, C.; Oishi, M.; Ogata, S.; Miyazaki, T.; Tanihara, M. Key Eng. Mater. 2005, 284-286, 281-284.

[139]Wang, R.; Weng, W.; Deng, X.; Cheng, K.; Liu, X.; Du, P.; Shen, G.; Han, G. Key Eng. Mater. 2006, 309-311, 223-226.

[140]Li, Y.; Weng, W.; Tam, K. C. Acta Biomater. 2007, 3, 251-254.

[141]Li, Y.; Li, D.; Weng, W. Key Eng. Mater. 2008, 368-372, 12061208.

[142] Vani, R.; Girija, E. K.; Elayaraja, K.; Prakash Parthiban, S.; Kesavamoorthy, R.; Narayana Kalkura, S. J. Mater. Sci. Mater. Med. 2009, 20, Suppl. 1, 43-48.

[143]Dorozhkin, S. V. J. Mater. Sci. 2007, 42, 1061-1095.

[144]Dorozhkin, S. V. Materials 2009, 2, 399-498.

[145]Narasaraju, T. S. B.; Phebe, D. E. J. Mater. Sci. 1996, 31, 1-21.

[146]Elliott, J. C. Structure and chemistry of the apatites and other calcium orthophosphates. Studies in inorganic chemistry, Vol. 18. Elsevier, Amsterdam, Netherlands, 1994, 389 pp.

[147]Brown, P. W.; Constantz B. (Eds.), Hydroxyapatite and related materials. CRC Press, Boca Raton, FL, USA, 1994, 343 pp.

[148] Amjad, Z. (Ed.), Calcium phosphates in biological and industrial systems. Kluwer Academic Publishers, Boston, MA, 1997, 529 pp.

[149]Hughes, J. M.; Kohn, M.; Rakovan, J. (Eds.), Phosphates: geochemical, geobiological and materials importance. Series: Reviews in mineralogy and geochemistry. Vol. 48. Mineralogical Society of America, Washington, DC, 2002, 742 pp.

[150]Chow, L. C.; Eanes, E. D. (Eds.), Octacalcium phosphate. Monographs in oral science. Vol. 18. S. Karger AG, Basel, 2001, $168 \mathrm{pp}$.

[151]Brès, E.; Hardouin, P. (Eds.), Les matériaux en phosphate de calcium. Aspects fondamentaux. / Calcium phosphate materials. Fundamentals. Sauramps Medical. Montpellier, 1998, 176 pp.

[152] Okuda, T.; Ioku, K.; Yonezawa, I.; Minagi, H.; Gonda, Y.; Kawachi, G.; Kamitakahara, M.; Shibata, Y.; Murayama, H.; Kurosawa, H.; Ikeda, T. Biomaterials 2008, 29, 2719-2728.

[153]Daculsi, G.; Bouler, J. M.; LeGeros, R. Z. Int. Rev. Cytology 1997, 172, 129-191.

[154] Astala, R.; Calderin, L.; Yin, X.; Stott, M. J. Chem. Mater. 2006, $18,413-422$.
[155]Zhu, X. D.; Zhang, H. J.; Fan, H. S.; Li, W.; Zhang, X. D. Acta Biomater. 2010, 6, 1536-1541.

[156]Bohner, M. Injury 2000, 31, Suppl. 4, D37-D47.

[157]Norton, J.; Malik, K. R.; Darr, J. A.; Rehman, I. Adv. Appl. Ceram. 2006, 105, 113-139.

[158] Yang, S.; Leong, K. F.; Du, Z.; Chua, C. K. Tissue Eng. 2002, 8, $1-11$.

[159] Yeong, W. Y.; Chua, C. K.; Leong, K. F.; Chandrasekaran, M. Trends Biotechnol. 2004, 22, 643-652.

[160]Hieu, L. C.; Zlatov, N.; Sloten, J. V.; Bohez, E.; Khanh, L.; Binh, P. H.; Oris, P.; Toshev, Y. Assembly Automation 2005, 25, 284-292.

[161]Eufinger, H.; Wehniöller, M.; Machtens, E.; Heuser, L.; Harders, A.; Kruse, D. J. Cranio Maxillofac. Surg. 1995, 23, 175-181.

[162] Klein, M.; Glatzer, C. Plastic Reconstruct. Surg. 2006, 117, 565570.

[163] Yin, L.; Song, X. F.; Song, Y. L.; Huang, T.; Li, J. Int. J. Machine Tools Manufact. 2006, 46, 1013-1026.

[164]Li, J.; Hsu, Y.; Luo, E.; Khadka, A.; Hu, J. Computer-aided design and manufacturing and rapid prototyped nanoscale hydroxyapatite/polyamide (n-HA/PA) construction for condylar defect caused by mandibular angle ostectomy. Aesthetic Plastic Surgery 2010, (early view).

[165] Yardimci, M. A.; Guceri, S. I.; Danforth, S. C. Ceram. Eng. Sci. Proceed. 1996, 17, 78-82.

[166]Bellini, A.; Shor, L.; Guceri, S. I. Rapid Prototyping J. 2005, 11, 214-220.

[167]Tan, K. H.; Chua, C. K.; Leong, K. F.; Cheah, C. M.; Cheang, P.; Abu Bakar, M. S.; Cha, S. W. Biomaterials 2003, 24, 31153123.

[168]Wiria, F. E.; Leong, K. F.; Chua, C. K.; Liu, Y. Acta Biomater. 2007, 3, 1-12.

[169]Zhou, W. Y.; Lee, S. H.; Wang, M.; Cheung, W. L.; Ip, W. Y. J. Mater. Sci. Mater. Med. 2008, 19, 2535-2540.

[170]Comesaña, R.; Lusquiños, F.; del Val, J.; Malot, T.; LópezÁlvarez, M.; Riveiro, A.; Quintero, F.; Boutinguiza, M.; Aubry, P.; de Carlos, A.; Pou, J. J. Eur. Ceram. Soc. 2011, 31, 29-41.

[171]Sachs, E.; Cima, M.; Williams, P.; Brancazio, D.; Cornie, J. J. Eng. Ind. 1992, 114, 481-488.

[172] Gbureck, U.; Hölzel, T.; Doillon, C. J.; Müller, F. A.; Barralet, J. E. Adv. Mater. 2007, 19, 795-800.

[173] Gbureck, U.; Hölzel, T.; Klammert, U.; Würzler, K.; Müller, F. A.; Barralet, J. E. Adv. Function. Mater. 2007, 17, 3940-3945.

[174] Vorndran, E.; Klarner, M.; Klammert, U.; Grover, L. M.; Patel, S.; Barralet, J. E.; Gbureck, U. Adv. Eng. Mater. 2008, 10, B67B71.

[175]Seitz, H.; Rieder, W.; Irsen, S.; Leukers, B.; Tille, C. J. Biomed. Mater. Res. B (Appl. Biomater.) 2005, 74B, 782-788.

[176]Leukers, B.; Gülkan, H.; Irsen, S. H.; Milz, S.; Tille, C.; Schieker, M.; Seitz, H. J. Mater. Sci. Mater. Med. 2005, 16, 1121-1124. 
[177]Habibovic, P.; Gbureck, U.; Doillon, C. J.; Bassett, D. C.; van Blitterswijk, C. A.; Barralet, J. E. Biomaterials 2008, 29, 944953.

[178]Fierz, F. C.; Beckmann, F.; Huser, M.; Irsen, S. H.; Leukers, B.; Witte, F.; Degistirici, O.; Andronache, A.; Thie, M.; Müller, B. Biomaterials 2008, 29, 3799-3806.

[179] Seitz, H.; Deisinger, U.; Leukers, B.; Detsch, R.; Ziegler, G. Adv. Eng. Mater. 2009, 11, B41-B46.

[180]Bergmann, C.; Lindner, M.; Zhang, W.; Koczur, K.; Kirsten, A.; Telle, R.; Fischer, H. J. Eur. Ceram. Soc. 2010, 30, 2563-2567.

[181]Porter, N. L.; Pilliar, R. M.; Grynpas, M. D. J. Biomed. Mater. Res. 2001, 56, 504-515.

[182]Leong, K. F.; Cheah, C. M.; Chua, C. K. Biomaterials 2003, 24, 2363-2378.

[183] Calvert, J. W.; Brenner, K. A.; Mooney, M. P.; Kumta, P.; Weiss, L. E. Rivista Italiana di Chirurgia Plastica 2004, 36, 145-150.

[184] Jongpaiboonkit, L.; Lin, C. Y.; Krebsbach, P. H.; Hollister, S. J.; Halloran, J. W. Key Eng. Mater. 2006, 309-311, 957-960.

[185]Shanjani, Y.; de Croos, J. N. A.; Pilliar, R. M.; Kandel, R. A.; Toyserkani, E. J. Biomed. Mater. Res. B (Appl. Biomater.) 2010, 93B, 510-519.

[186]Chu, T. M. G.; Halloran, J. W.; Hollister, S. J.; Feinberg, S. E. J. Mater. Sci. Mater. Med. 2001, 12, 471-478.

[187]Li, X.; Li, D.; Lu, B.; Tang, Y.; Wang, L.; Wang, Z. Rapid Prototyping J. 2005, 11, 312-318.

[188] Woesz, A.; Rumpler, M.; Stampfl, J.; Varga, F.; Fratzl-Zelman, N.; Roschger, P.; Klaushofer, K.; Fratzl, P. Mater. Sci. Eng. C 2005, 25, 181-186.

[189]Li, X.; Li, D.; Lu, B.; Wang, C. J. Porous Mater. 2008, 15, 667671.

[190] Saber-Samandari, S.; Gross, K. A. Biomaterials 2010, 31, 63866393.

[191]Nather, A. (Ed.), Bone grafts and bone substitutes: basic science and clinical applications. World Scientific, Singapore, 2005, 592 pp.

[192]Bártolo, P.; Bidanda, B. (Eds.), Bio-materials and prototyping applications in medicine. Springer, New York, USA, 2008, 216 pp.

[193]Narayan, R. J.; Jin, C.; Doraiswamy, A.; Mihailescu, I. N.; Jelinek, M.; Ovsianikov, A.; Chichkov, B.; Chrisey, D. B. Adv. Eng. Mater. 2005, 7, 1083-1098.

[194] Kokubo, T. (Ed.), Bioceramics and their clinical applications. Woodhead Publishing, Abington, Cambridge, UK, 2008, 784 pp.

[195]Narayan, R. (Ed.), Biomedical materials. Springer, New York, USA, 2009, 566 pp.

[196]Raksujarit, A.; Pengpat, K.; Rujijanagul, G.; Tunkasiri, T. Mater. Design 2010, 31, 1658-1660.

[197]Park, J. Bioceramics: properties, characterizations, and applications. Springer, New York, USA, 2008, 364 pp.

[198]Rodríguez-Lorenzo, L. M.; Vallet-Regí, M.; Ferreira, J. M. F. Biomaterials 2001, 22, 583-588.
[199]Nazarpak, M. H.; Solati-Hashjin, M.; Moztarzadeh, F. J. Ceram. Process. Res. 2009, 10, 54-57.

[200]Itoh, H.; Wakisaka, Y.; Ohnuma, Y.; Kuboki, Y. Dent. Mater. 1994, 13, 25-35.

[201] Gautier, H.; Merle, C.; Auget, J. L.; Daculsi, G. Biomaterials 2000, 21, 243-249.

[202]Tadic, D.; Epple, M. Biomaterials 2003, 24, 4565-4571.

[203]Pecqueux, F.; Tancret, F.; Payraudeau, N.; Bouler, J. M. J. Eur. Ceram. Soc. 2010, 30, 819-829.

[204]Uematsu, K.; Takagi, M.; Honda, T.; Uchida, N.; Saito, K. J. Am. Ceram. Soc. 1989, 72, 1476-1478.

[205]Onoki, T.; Hashida, T. Surf. Coat. Technol. 2006, 200, 68016807.

[206] Takikawa, K.; Akao, M. J. Mater. Sci. Mater. Med. 1996, 7, 439445.

[207]Viana, M.; Désiré, A.; Chevalier, E.; Champion, E.; Chotard, R.; Chulia, D. Key Eng. Mater. 2009, 396-398, 535-538.

[208]Chevalier, E.; Viana, M.; Cazalbou, S.; Chulia, D. Drug Development and Industrial Pharmacy 2009, 35, 1255-1263.

[209]Reikerås, O.; Johansson, C. B.; Sundfeldt, M. J. Long-Term Eff. Med. Implant. 2006, 16, 157-164.

[210]Rao, R. R.; Kannan, T. S. J. Am. Ceram. Soc. 2001, 84, 17101716.

[211]Sakka, Y.; Takahashi, K.; Matsuda, N.; Suzuki, T. S. Mater. Transact. 2007, 48, 2861-2866.

[212]Zhang, Y.; Yokogawa, Y.; Feng, X.; Tao, Y.; Li, Y. Ceram. Int. 2010, 36, 107-113.

[213]Liu, Y.; Kim, J. H.; Young, D.; Kim, S.; Nishimoto, S. K.; Yang, Y. J. Biomed. Mater. Res. A 2010, 92A, 997-1006.

[214] Sepulveda, P.; Ortega, F. S.; Innocentini, M. D. M.; Pandolfelli, V. C. J. Am. Ceram. Soc. 2000, 83, 3021-3024.

[215]Padilla, S.; Vallet-Regí, M.; Ginebra, M. P.; Gil, F. J. J. Eur. Ceram. Soc. 2005, 25, 375-383.

[216] Sánchez-Salcedo, S.; Werner, J.; Vallet-Regí, M. Acta Biomater. 2008, 4, 913-922.

[217]Chen, B.; Zhang, T.; Zhang, J.; Lin, Q.; Jiang, D. Ceram. Int. 2008, 34, 359-364.

[218] Marcassoli, P.; Cabrini, M.; Tirillò, J.; Bartuli, C.; Palmero, P.; Montanaro, L. Key Eng. Mater. 2010, 417-418, 565-568.

[219]Padilla, S.; Roman, J.; Vallet-Regí, M. J. Mater. Sci. Mater. Med. 2002, 13, 1193-1197.

[220]Fomin, A. S.; Barinov, S. M.; Ievlev, V. M.; Smirnov, V. V.; Mikhailov, B. P.; Belonogov, E. K.; Drozdova, N. A. Dokl. Chem. 2008, 418, 22-25.

[221] Kankawa, Y.; Kaneko, Y.; Saitou, K. J. Ceram. Soc. Jpn. 1991, 99, 438-442.

[222] Kwon, S. H.; Jun, Y. K.; Hong, S. H.; Lee, I. S.; Kim, H. E.; Won, Y. Y. J. Am. Ceram. Soc. 2002, 85, 3129-3131.

[223]Fooki, A. C. B. M.; Aparecida, A. H.; Fideles, T. B.; Costa, R. C.; Fook, M. V. L. Key Eng. Mater. 2009, 396-398, 703-706.

[224] Sopyan, I.; Kaur, J. Ceram. Int. 2009, 35, 3161-3168. 
[225]Bellucci, D.; Cannillo, V.; Sola, A. Mater. Lett. 2010, 64, 203206.

[226] Velayudhan, S.; Ramesh, P.; Sunny, M. C.; Varma, H. K. Mater. Lett. 2000, 46, 142-146.

[227] Yang, H. Y.; Thompson, I.; Yang, S. F.; Chi, X. P.; Evans, J. R. G.; Cook, R. J. J. Mater. Sci. Mater. Med. 2008, 19, 3345-3353.

[228] Yang, S.; Yang, H.; Chi, X.; Evans, J. R. G.; Thompson, I.; Cook, R. J.; Robinson, P. Mater. Design 2008, 29, 1802-1809.

[229] Muthutantri, A. I.; Huang, J.; Edirisinghe, M. J.; Bretcanu, O.; Boccaccini, A. R. Biomed. Mater. 2008, 3, 25009 (14 pages).

[230]Roncari, E.; Galassi, C.; Pinasco, P. J. Mater. Sci. Lett. 2000, 19, 33-35.

[231]Tian, T.; Jiang, D.; Zhang, J.; Lin, Q. J. Eur. Ceram. Soc. 2007, 27, 2671-2677.

[232] Suzuki, S.; Itoh, K.; Ohgaki, M.; Ohtani, M.; Ozawa, M. Ceram. Int. 1999, 25, 287-291.

[233] Suchanek, W. L.; Yoshimura, M. J. Mater. Res. 1998, 13, 94117.

[234] Yang, T. Y.; Lee, J. M.; Yoon, S. Y.; Park, H. C. J. Mater. Sci. Mater. Med. 2010, 21, 1495-1502.

[235] Inoue, K.; Sassa, K.; Yokogawa, Y.; Sakka, Y.; Okido, M.; Asai, S. Mater. Transact. 2003, 44, 1133-1137.

[236] Iwai, K.; Akiyama, J.; Asai, S. Mater. Sci. Forum 2007, 561 565, Part 2, 1565-1568.

[237]Iwai, K.; Akiyama, J.; Tanase, T.; Asai, S. Mater. Sci. Forum 2007, 539-543, Part 1, 716-719.

[238] Sakka, Y.; Takahashi, K.; Suzuki, T. S.; Ito, S.; Matsuda, N. Mater. Sci. Eng. A 2008, 475, 27-33.

[239] Kang, J.; Hadfield, M. Proc. Inst. Mech. Eng. B 2001, 215, 6978.

[240] Kurella, A.; Dahotre, N. B. J. Biomater. Appl. 2005, 20, 5-50.

[241] Oktar, F. N.; Genc, Y.; Goller, G.; Erkmen, E. Z.; Ozyegin, L. S.; Toykan, D.; Demirkiran, H.; Haybat, H. Key Eng. Mater. 2004, 264-268, 2087-2090.

[242] Georgiou, G.; Knowles, J. C.; Barralet, J. E. J. Mater. Sci. 2004, 39, 2205-2208.

[243]Fellah, B. H.; Layrolle, P. Acta Biomater. 2009, 5, 735-742.

[244]Dudek, A.; Kolan, C. Diffusion and Defect Data B: Solid State Phenomena 2010, 165, 25-30.

[245]Ben Ayed, F.; Bouaziz, J.; Bouzouita, K. J. Eur. Ceram. Soc. 2000, 20, 1069-1076.

[246]He, Z.; Ma, J.; Wang, C. Biomaterials 2005, 26, 1613-1621.

[247] Khalil, K. A.; Kim, S. W.; Dharmaraj, N.; Kim, K. W.; Kim, H. Y. J. Mater. Process. Technol. 2007, 187-188, 417-420.

[248]Landi, E.; Tampieri, A.; Celotti, G.; Sprio, S. J. Eur. Ceram. Soc. 2000, 20, 2377-2387.

[249]Laasri, S.; Taha, M.; Laghzizil, A.; Hlil, E. K.; Chevalier, J. Mater. Res. Bull. 2010, 45, 1433-1437.

[250]Ruys, A. J.; Wei, M.; Sorrell, C. C.; Dickson, M. R.; Brandwood, A.; Milthorpe, B. K. Biomaterials 1995, 16, 409415.
[251] van Landuyt, P.; Li, F.; Keustermans, J. P.; Streydio, J. M.; Delannay, F.; Munting, E. J. Mater. Sci. Mater. Med. 1995, 6, 813.

[252]Haberko, K.; Bućko, M. M.; Brzezińska-Miecznik, J.; Haberko, M.; Mozgawa, W.; Panz, T.; Pyda, A.; Zarebski, J. J. Eur. Ceram. Soc. 2006, 26, 537-542.

[253]Haberko, K.; Bućko, M. M.; Mozgawa, W.; Pyda, A.; Brzezińska-Miecznik, J.; Carpentier, J. Ceram. Int. 2009, 35, 2537-2540.

[254]Janus, A. M.; Faryna, M.; Haberko, K.; Rakowska, A.; Panz, T. Mikrochim. Acta 2008, 161, 349-353.

[255]Bahrololoom, M. E.; Javidi, M.; Javadpour, S.; Ma, J. J. Ceram. Process. Res. 2009, 10, 129-138.

[256] Mostafa, N. Y. Mater. Chem. Phys. 2005, 94, 333-341.

[257]Suchanek, W.; Yashima, M.; Kakihana, M.; Yoshimura, M. Biomaterials 1997, 18, 923-933.

[258]Kalita, S. J.; Bose, S.; Bandyopadhyay, A.; Hosick, H. L. Ceram. Transact. 2003, 147, 63-72.

[259] Kalita, S. J.; Bose, S.; Hosick, H. L.; Bandyopadhyay, A. Biomaterials 2004, 25, 2331-2339.

[260] Safronova, T. V.; Putlyaev, V. I.; Shekhirev, M. A.; Tretyakov, Y. D.; Kuznetsov, A. V.; Belyakov, A. V. J. Eur. Ceram. Soc. 2009, 29, 1925-1932.

[261] Muralithran, G.; Ramesh, S. Ceram. Int. 2000, 26, 221-230.

[262] Bernache-Assollant, D.; Ababou, A.; Champion, E.; Heughebaert, M. J. Eur. Ceram. Soc. 2003, 23, 229-241.

[263]Chen, S.; Wang, W.; Kono, H.; Sassa, K.; Asai, S. J. Cryst. Growth 2010, 312, 323-326.

[264]Ramesh, S.; Tan, C. Y.; Bhaduri, S. B.; Teng, W. D.; Sopyan I. J. Mater. Process. Technol. 2008, 206, 221-230.

[265]Wang, J.; Shaw, L. L. J. Am. Ceram. Soc. 2010, 93, 601-604.

[266] Kobayashi, S.; Kawai, W.; Wakayama, S. J. Mater. Sci. Mater. Med. 2006, 17, 1089-1093.

[267] Kasuga, T.; Ota, Y.; Tsuji, K.; Abe, Y. J. Am. Ceram. Soc. 1996, 79, 1821-1824.

[268] Suchanek, W. L.; Yoshimura, M. J. Am. Ceram. Soc. 1998, 81, 765-767.

[269] Kim, Y.; Kim, S. R.; Song, H.; Yoon, H. Mater. Sci. Forum 2005, 486-487, 117-120.

[270]Li, J. G.; Hashida, T. J. Mater. Sci. 2007, 42, 5013-5019.

[271]Li, J. G.; Hashida, T. J. Am. Ceram. Soc. 2006, 89, 3544-3546.

[272]Halouani, R.; Bernache-Assolant, D.; Champion, E.; Ababou, A. J. Mater. Sci. Mater. Med. 1994, 5, 563-568.

[273]Nakahira, A.; Murakami, T.; Onoki, T.; Hashida, T.; Hosoi, K. J. Am. Ceram. Soc. 2005, 88, 1334-1336.

[274] Auger, M. A.; Savoini, B.; Muñoz, A.; Leguey, T.; Monge, M. A.; Pareja, R.; Victoria, J. Ceram. Int. 2009, 35, 2373-2380.

[275]Fang, Y.; Agrawal, D. K.; Roy, D. M.; Roy, R. J. Mater. Res. 1994, 9, 180-187.

[276] Yang, Y.; Ong, J. L.; Tian, J. J. Mater. Sci. Lett. 2002, 21, 67-69.

[277]Nath, S.; Basu, B.; Sinha, A. Trends Biomater. Artif. Organs 2006, 19, 93-98. 
[278]Ramesh, S.; Tan, C. Y.; Bhaduri, S. B.; Teng, W. D. Ceram. Int. 2007, 33, 1363-1367.

[279] Silva, C. C.; Graça, M. P. F.; Sombra, A. S. B.; Valente, M. A. Phys. Rev. B Condens. Matter 2009, 404, 1503-1508.

[280]Chanda, A.; Dasgupta, S.; Bose, S.; Bandyopadhyay, A. Mater. Sci. Eng. C 2009, 29, 1144-1149.

[281] Veljović, D.; Zalite, I.; Palcevskis, E.; Smiciklas, I.; Petrović, R.; Janaćković, D. Ceram. Int. 2010, 36, 595-603.

[282] Kalita, S. J.; Verma, S. Mater. Sci. Eng. C 2010, 30, 295-303.

[283] Veljović, D.; Palcevskis, E.; Dindune, A.; Putić, S.; Balać, I.; Petrović, R.; Janaćković, D. J. Mater. Sci. 2010, 45, 3175-3183.

[284] Gu, Y. W.; Loh, N. H.; Khor, K. A.; Tor, S. B.; Cheang, P. Biomaterials 2002, 23, 37-43.

[285]Guo, X.; Xiao, P.; Liu, J.; Shen, Z. J. Am. Ceram. Soc. 2005, 88, 1026-1029.

[286] Drouet, C.; Largeot, C.; Raimbeaux, G.; Estournès, C.; Dechambre, G.; Combes, C.; Rey, C. Adv. Sci. Tech. 2006, 49, 45-50.

[287]Li, H.; Khor, K. A.; Chow, V.; Cheang, P. J. Biomed. Mater. Res. A 2007, 82A, 296-303.

[288] Nakamura, T.; Fukuhara, T.; Izui, H. Ceram. Transact. 2006, 194, 265-272.

[289] Kawagoe, D.; Ioku, K.; Fujimori, H.; Goto, S. J. Ceram. Soc. Jpn. 2004, 112, 462-463.

[290]Zhang, F.; Lin, K.; Chang, J.; Lu, J.; Ning, C. J. Eur. Ceram. Soc. 2008, 28, 539-545.

[291] Grossin, D.; Rollin-Martinet, S.; Estournès, C.; Rossignol, F.; Champion, E.; Combes, C.; Rey, C.; Geoffroy, C.; Drouet, C. Acta Biomater. 2010, 6, 577-585.

[292] Chesnaud, A.; Bogicevic, C.; Karolak, F.; Estournès, C.; Dezanneau, G. Chem. Comm. 2007, 1550-1552.

[293] Ishihara, S.; Matsumoto, T.; Onoki, T.; Sohmura, T.; Nakahira, A. Mater. Sci. Eng. C 2009, 29, 1885-1888.

[294] Yanagisawa, K.; Kim, J. H.; Sakata, C.; Onda, A.; Sasabe, E.; Yamamoto, T.; Matamoros-Veloza, Z.; Rendón-Angeles, J. C. Zeitschrift fur Naturforschung - Section B J. Chem. Sci. 2010, 65, 1038-1044.

[295] Gross, K. A.; Berndt C. C. Biomedical application of apatites. In: Phosphates: geochemical, geobiological and materials importance, Series: Reviews in Mineralogy and Geochemistry. Vol. 48. Hughes, J. M.; Kohn, M.; Rakovan, J. Eds.; Mineralogical Society of America: Washington, D. C.; USA, 2002, pp. 631-672.

[296]LeGeros, R. Z.; LeGeros, J. P. Dense hydroxyapatite. In: An introduction to bioceramics. Hench, L. L.; Wilson, J. Eds.; World Scientific: London, UK, 1993, pp. 139-180.

[297]Evans, J. R. G. J. Eur. Ceram. Soc. 2008, 28, 1421-1432.

[298]Black, J. Biological performance of materials: fundamentals of biocompatibility. Fourth Ed. CRC Press, Boca Raton, FL, USA, 2005, 520 pp.

[299]Benaqqa, C.; Chevalier, J.; Saädaoui, M.; Fantozzi, G. Biomaterials 2005, 26, 6106-6112.
[300]Linhart, W.; Briem, D.; Amling, M.; Rueger, J. M.; Windolf, J. Unfallchirurg. 2004, 107, 154-157.

[301] In materials science, fracture toughness is a property, which describes the ability of a material containing a crack to resist fracture and is one of the most important properties of any material for virtually all design applications.

[302]Ramesh, S.; Tan, C. Y.; Sopyan, I.; Hamdi, M.; Teng, W. D. Sci. Technol. Adv. Mater. 2007, 8, 124-130.

[303] The nature of flaws in most ceramics is statistical. As such, the strength of ceramics is not one specific value, but a distribution of strengths. The Weibull modulus is a measure of the distribution of flaws, usually for a brittle material. The modulus is a dimensionless number corresponding to the variability in measured strength and reflects the distribution of flaws in the material.

[304]Suzuki, S.; Sakamura, M.; Ichiyanagi, M.; Ozawa, M. Ceram. Int. 2004, 30, 625-627.

[305] Strength can be defined as the maximum tensile stresses that a material can endure before fracture occurs. It might also be defined as force per unit area required to initiate and propagate a crack to the fracture point [194].

[306] In materials science, fatigue is the progressive and localized structural damage that occurs when a material is subjected to cyclic loading.

[307]le Huec, J. C.; Schaeverbeke, T.; Clement, D.; Faber, J.; le Rebeller, A. Biomaterials 1995, 16, 113-118.

[308]Hsu, Y. H.; Turner, I. G.; Miles, A. W. J. Mater. Sci. Mater. Med. 2009, 20, 2367-2374.

[309] The elastic modulus is the ratio of stress to strain below the proportional limit. It represents the magnitude of the interatomic stiffness of a material within the elastic range when tensile or compressive forces are applied. It is also an indication of the amount of reversible deformation that will occur in a structure when a load is applied [194].

[310] de Aza, P. N.; de Aza, A. H; de Aza, S. Bol. Soc. Esp. Ceram. V. 2005, 44, 135-145.

[311]Ching, W. Y.; Rulis, P.; Misra, A. Acta Biomater. 2009, 5, 30673075.

[312] Hardness of a material usually is considered as a measure of the resistance to permanent indentation. A standardized force or weight is applied to an indenter pressing into the surface of a material to create a symmetrical shaped indentation [194].

[313] Poisson's ratio (v), named after Siméon Poisson, is the ratio, when a sample object is stretched, of the contraction or transverse strain (perpendicular to the applied load), to the extension or axial strain (in the direction of the applied load).

[314]Burger, E. L.; Patel, V. Orthopedics 2007, 30, 939-942.

[315]Rodriguez-Lorenzo, L. M.; Vallet-Regí, M.; Ferreira, J. M. F.; Ginebra, M. P.; Aparicio, C.; Planell, J. J. Biomed. Mater. Res. 2002, 60, 159-166.

[316]Dorozhkin, S. V. J. Mater. Sci. 2009, 44, 2343-2387. 
[317]Bouslama, N.; Ben Ayed, F.; Bouaziz, J. Ceram. Int. 2009, 35, 1909-1917.

[318] Suchanek, W.; Yashima, M.; Kakihana, M.; Yoshimura, M. Biomaterials 1996, 17, 1715-1723.

[319] Suchanek, W.; Yashima, M.; Kakihana, M.; Yoshimura, M. J. Am. Ceram. Soc. 1997, 80, 2805-2813.

[320] Simsek, D.; Ciftcioglu, R.; Guden, M.; Ciftcioglu, M.; Harsa, S. Key Eng. Mater. 2004, 264-268, 1985-1988.

[321]Bose, S.; Banerjee, A.; Dasgupta, S.; Bandyopadhyay, A. J. Am. Ceram. Soc. 2009, 92, 323-330.

[322] Shiota, T.; Shibata, M.; Yasuda, K.; Matsuo, Y. J. Ceram. Soc. Jpn. 2009, 116, 1002-1005.

[323] Dorozhkin, S. V.; Ajaal, T. Proc. Inst. Mech. Eng. Part H: J. Eng. Med. 2009, 223, 459-470.

[324]Dorozhkin, S. V.; Ajaal, T. J. Biomim. Biomater. Tissue. Eng. 2009, 4, 27-39.

[325] He, L. H.; Standard, O. C.; Huang, T. T.; Latella, B. A.; Swain, M. V. Acta Biomater. 2008, 4, 577-586.

[326] Nagai, M.; Nishino, T. Solid State Ionics 1988, 28-30, 14561461.

[327] Yamashita, K.; Owada, H.; Umegaki, T.; Kanazawa, T.; Futagamu, T. Solid State Ionics 1988, 28-30, 660-663.

[328] Mahabole, M. P.; Aiyer, R. C.; Ramakrishna, C. V.; Sreedhar, B.; Khairnar, R. S. Bull. Mater. Sci. 2005, 28, 535-545.

[329]Fanovich, M. A.; Castro, M. S.; Lopez, J. M. P. Ceram. Int. 1999, 25, 517-522.

[330] Valdes, J. J. P.; Rodriguez, A. V.; Carrio, J. G. J. Mater. Res. 1995, 10, 2174-2177.

[331]Bensaoud, A.; Bouhaouss, A.; Ferhat, M. J. Solid State Electrochem. 2001, 5, 362-365.

[332] Tanaka, Y.; Nakamura, M.; Nagai, A.; Toyama, T.; Yamashita, K. Mater. Sci. Eng. B 2009, 161, 115-119.

[333]Tanaka, Y.; Takata, S.; Shimoe, K.; Nakamura, M.; Nagai, A.; Toyama, T.; Yamashita, K. J. Ceram. Soc. Jpn. 2008, 116, 815821.

[334] Nakamura, S.; Takeda, H.; Yamashita, K. J. Appl. Phys. 2001, 89, 5386-5392.

[335] Gittings, J. P.; Bowen, C. R.; Turner, I. G.; Baxter, F. R.; Chaudhuri, J. B. Mater. Sci. Forum 2008, 587-588, 91-95.

[336] Itoh, S.; Nakamura, S.; Kobayashi, T.; Shinomiya, K.; Yamashita, K.; Itoh, S. Calcif. Tissue Int. 2006, 78, 133-142.

[337]Iwasaki, T.; Tanaka, Y.; Nakamura, M.; Nagai, A.; Hashimoto, K.; Toda, Y.; Katayama, K.; Yamashita, K. J. Am. Ceram. Soc. 2008, 91, 3943-3949.

[338] Itoh, S.; Nakamura, S.; Kobayashi, T.; Shinomiya, K.; Yamashita, K. Biomaterials 2006, 27, 5572-5579.

[339] Kobayashi, T.; Itoh, S.; Nakamura, S.; Nakamura, M.; Shinomiya, K.; Yamashita, K. J. Biomed. Mater. Res. A 2007, 82A, 145-151.

[340]Bodhak S.; Bose S.; Bandyopadhyay A. Acta Biomater. 2009, 5, 2178-2188.
[341] Yamashita, K.; Oikawa, N.; Umegaki, T. Chem. Mater. 1996, 8, 2697-2700.

[342]Teng, N. C.; Nakamura, S.; Takagi, Y.; Yamashita, Y.; Ohgaki, M.; Yamashita, K. J. Dent. Res. 2001, 80, 1925-1929.

[343] Kobayashi, T.; Nakamura, S.; Yamashita, K. J. Biomed. Mater. Res. 2001, 57, 477-484.

[344]Park, Y. J.; Hwang, K. S.; Song, J. E.; Ong, J. L.; Rawls, H. R. Biomaterials 2002, 23, 3859-3864.

[345]Hwang, K. S.; Song, J. E.; Jo, J. W.; Yang, H. S.; Park, Y. J.; Ong, J. L.; Rawls, H. R. J. Mater. Sci. Mater. Med. 2002, 13, 133-138.

[346] Yamashita, K. Mater. Sci. Forum 2003, 426-432, 3237-3242.

[347]Nakamura, S.; Kobayashi, T.; Yamashita, K. Key Eng. Mater. 2005, 284-286, 897-900.

[348] Kato, R.; Nakamura, S.; Katayama, K.; Yamashita, K. J. Biomed. Mater. Res. A 2005, 74A, 652-658.

[349] Nakamura, S.; Kobayashi, T.; Nakamura, M.; Itoh, S.; Yamashita, K. J. Biomed. Mater. Res. A 2010, 92A, 267-275.

[350] Itoh, S.; Nakamura, S.; Nakamura, M.; Shinomiya, K.; Yamashita, K. Artif. Organs 2006, 30, 863-869.

[351] Nakamura, M.; Nagai, A.; Ohashi, N.; Tanaka, Y.; Sekilima, Y.; Nakamura, S. Key Eng. Mater. 2008, 361-363, 1055-1058.

[352] Nakamura, M.; Nagai, A.; Tanaka, Y.; Sekilima, Y.; Yamashita, K. J. Biomed. Mater. Res. A 2010, 92A, 783-790.

[353] Nakamura, S.; Kobayashi, T.; Yamashita, K. J. Biomed. Mater. Res. 2002, 61, 593-599.

[354] Wang, W.; Itoh, S.; Tanaka, Y.; Nagai, A.; Yamashita, K. Acta Biomater. 2009, 5, 3132-3140.

[355] Nakamura, M.; Niwa, K.; Nakamura, S.; Sekijima, Y.; Yamashita, K. J. Biomed. Mater. Res. B (Appl. Biomater.) 2007, 82B, 29-36.

[356]Nagai, M.; Shibuya, Y.; Nishino, T.; Saeki, T.; Owada, H.; Yamashita, K.; Umegaki, T. J. Mater. Sci. 1991, 26, 2949-2953.

[357]Laghzizil, A.; Elherch, N.; Bouhaouss, A.; Lorente, G.; Coradin, T.; Livage, J. Mater. Res. Bull. 2001, 36, 953-962.

[358]Louati, B.; Guidara, K.; Gargouri, M. J. Alloys Compd. 2009, 472, 347-351.

[359] Gittings, J. P.; Bowen, C. R.; Dent, A. C.; Turner, I. G.; Baxter, F. R.; Chaudhuri, J. B. Acta Biomater. 2009, 5, 743-754.

[360]Tofail, S. A. M.; Baldisserri, C.; Haverty, D.; McMonagle, J. B.; Erhart, J. J. Appl. Phys. 2009, 106, 106104.

[361]Ioku, K. J. Ceram. Soc. Jpn. 2010, 118, 775-783.

[362]Fang, Y.; Agrawal, D. K.; Roy, D. M.; Roy, R. Mater. Lett. 1995, 23, 147-151.

[363] Kotobuki, N.; Kawagoe, D.; Fujimori, H.; Goto, S.; Loku, K.; Ohgushi, H. Key Eng. Mater. 2004, 254-256, 1055-1058.

[364] Kotobuki, N.; Ioku, K.; Kawagoe, D.; Nomura, D.; Fujimori, H.; Goto, S.; Ohgushi, H. Key Eng. Mater. 2005, 284-286, 663-666.

[365] Varma, H.; Vijayan, S. P.; Babu, S. S. J. Am. Ceram. Soc. 2002, 85, 493-495. 
[366] Watanabe, Y.; Ikoma, T.; Monkawa, A.; Suetsugu, Y.; Yamada, H.; Tanaka, J.; Moriyoshi, Y. J. Am. Ceram. Soc. 2005, 88, 243245.

[367] Kotobuki, N.; Ioku, K.; Kawagoe, D.; Fujimori, H.; Goto, S.; Ohgushi, H. Biomaterials 2005, 26, 779-785.

[368]John, A.; Varma, H. K.; Vijayan, S.; Bernhardt, A.; Lode, A.; Vogel, A.; Burmeister, B.; Hanke, T.; Domaschke, H.; Gelinsky, M. Biomed. Mater. 2009, 4, 015007 (9 pages).

[369] Kotobuki, N.; Kawagoe, D.; Nomura, D.; Katou, Y.; Muraki, K.; Fujimori, H.; Goto, S.; Ioku, K.; Ohgushi, H. J. Mater. Sci. Mater. Med. 2006, 17, 33-41.

[370] Wang, J.; Shaw, L. L. Scripta Mater. 2010, 63, 593-596.

[371] Kobune, M.; Mineshige, A.; Fujii, S.; Iida, H. J. Ceram. Soc. Jpn. 1997, 105, 210-213.

[372] Barralet, J. E.; Fleming, G. J. P.; Campion, C.; Harris, J. J.; Wright, A. J. J. Mater. Sci. 2003, 38, 3979-3993.

[373] Chaudhry, A. A.; Yan, H.; Gong, K.; Inam, F.; Viola, G.; Reece, M. J.; Goodall, J. B. M.; ur Rehman, I.; McNeil-Watson, F. K.; Corbett, J. C. W.; Knowles, J. C, Darr, J. A. Acta Biomater. 2011, 7, 791-799.

[374] Tancred, D. C.; McCormack, B. A.; Carr, A. J. Biomaterials 1998, 19, 2303-2311.

[375] Miao, X.; Sun, D. Materials 2010, 3, 26-47.

[376] Gauthier, O.; Bouler, J. M.; Weiss, P.; Bosco, J.; Daculsi, G.; Aguado, E. J. Biomed. Mater. Res. 1999, 47, 28-35.

[377]Hing, K. A.; Best, S. M.; Bonfield, W. J. Mater. Sci. Mater. Med. 1999, 10, 135-145.

[378] Carotenuto, G.; Spagnuolo, G.; Ambrosio, L.; Nicolais, L. J. Mater. Sci. Mater. Med. 1999, 10, 671-676.

[379]Bucholz, R. W.; Carlton, A.; Holmes, R. Clin. Orthop. 1989, 240, 53-62.

[380] Cavagna, R.; Daculsi, G.; Bouler, J. M. J. Long Term Eff. Med. Implants 1999, 9, 403-412.

[381]Lu, J. X.; Flautre, B.; Anselme, K.; Hardouin, P.; Gallur, A.; Descamps, M.; Thierry, B. J. Mater. Sci. Mater. Med. 1999, 10, 111-120.

[382] Ayers, R. A.; Simske, S. J.; Nunes, C. R.; Wolford, L. M. J. Oral Maxillof. Surg. 1998, 56, Suppl. 5, 1297-1302.

[383] Jones, A. C.; Arns, C. H.; Sheppard, A. P.; Hutmacher, D. W.; Milthorpe, B. K.; Knackstedt, M. A. Biomaterials 2007, 28, 2491-2504.

[384] Karageorgiou, V.; Kaplan, D. Biomaterials 2005, 26, 5474-5491.

[385]Tamai, N.; Myoui, A.; Kudawara, I.; Ueda, T.; Yoshikawa, H. J. Orthop. Sci. 2010, 15, 560-568.

[386] Ohgushi, H.; Goldberg, V. M.; Caplan, A. I. J. Orthop. Res. 1989, 7, 568-578.

[387]Cheung, H. S.; Haak, M. H. Biomaterials 1989, 10, 63-67.

[388]Zyman, Z.; Ivanov, I.; Glushko, V.; Dedukh, N.; Malyshkina, S. Biomaterials 1998, 19, 1269-1273.

[389] Yoshikawa, T.; Ohgushi, H.; Tamai, S. J. Biomed. Mater. Res. 1996, 32, 481-492.
[390]Chang, B. S.; Lee, C. K.; Hong, K. S.; Youn, H. J.; Ryu, H. S.; Chung, S. S.; Park, K. Biomaterials 2000, 21, 1291-1298.

[391]Flautre, B.; Descamps, M.; Delecourt, C.; Blary, M. C.; Hardouin, P. J. Mater. Sci. Mater. Med. 2001, 12, 679-682.

[392] McAfee, P. C.; Cunningham, B. W.; Orbegoso, D. O.; Sefter, J. C.; Dmitriev, A. E.; Fedder, I. L. Spine 2003, 28, 332-340.

[393]Tamai, N.; Myoui, A.; Tomita, T.; Nakase, T.; Tanaka, J.; Ochi, T.; Yoshikawa, H. J. Biomed. Mater. Res. 2002, 59, 110-117.

[394] Mastrogiacomo, M.; Scaglione, S.; Martinetti, R.; Dolcini, L.; Beltrame, F.; Cancedda, R.; Quarto, R. Biomaterials 2006, 27, 3230-3237.

[395] Okamoto, M.; Dohi, Y.; Ohgushi, H.; Shimaoka, H.; Ikeuchi, M.; Matsushima, A.; Yonemasu, K.; Hosoi, H. J. Mater. Sci. Mater. Med. 2006, 17, 327-336.

[396]Zhang, L.; Hanagata, N.; Maeda, M.; Minowa, T.; Ikoma, T.; Fan, H.; Zhang, X. Sci. Technol. Adv. Mater. 2009, 10, 025003 (9 pages).

[397] Omae, H.; Mochizuki, Y.; Yokoya, S.; Adachi, N.; Ochi, M. J. Biomed. Mater. Res. A 2006, 79A, 329-337.

[398] Yoshikawa, H.; Tamai, N.; Murase, T.; Myoui, A. J. R. Soc. Interface 2009, 6, S341-S348.

[399] Ishikawa, K. Materials 2010, 3, 1138-1155.

[400]Takagi, S.; Chow, L. C. J. Biomed. Mater. Res. 2001, 12, 135139.

[401] Walsh, D.; Tanaka, J. J. Mater. Sci. Mater. Med. 2001, 12, 339344.

[402] Chevalier, E.; Chulia, D.; Pouget, C.; Viana, M. J. Pharm. Sci. 2008, 97, 1135-1154.

[403] Komlev, V. S.; Barinov, S. M. J. Mater. Sci. Mater. Med. 2002, 13, 295-299.

[404] Sepulveda, P.; Binner, J. G.; Rogero, S. O.; Higa, O. Z.; Bressiani, J. C. J. Biomed. Mater. Res. 2000, 50, 27-34.

[405]Hsu, Y. H.; Turner, I. G.; Miles, A. W. J. Mater. Sci. Mater. Med. 2007, 18, 2319-2329.

[406]Zhang, H. G.; Zhu, Q. J. Mater. Sci. Mater. Med. 2007, 18, 1825-1829.

[407]le Ray, A. M.; Gautier, H.; Bouler, J. M.; Weiss, P.; Merle, C. Ceram. Int. 2010, 36, 93-101.

[408] Guda, T.; Appleford, M.; Oh, S.; Ong, J. L. Curr. Top. Medicinal Chem. 2008, 8, 290-299.

[409] Ota, Y.; Kasuga, T.; Abe, Y. J. Am. Ceram. Soc. 1997, 80, 225231.

[410] White, E.; Shors, E. C. Dent. Clin. North Am. 1986, 30, 49-67.

[411]Descamps, M.; Duhoo, T.; Monchau, F.; Lu, J.; Hardouin, P.; Hornez, J. C.; Leriche, A. J. Eur. Ceram. Soc. 2008, 28, 149157.

[412] Engin, N. O.; Tas, A. C. J. Eur. Ceram. Soc. 1999, 19, 25692572.

[413]Liu, D. M. J. Mater. Sci. Mater. Med. 1997, 8, 227-232.

[414]Rivera-Munoz, E.; Diaz, J. R.; Rodriguez, J. R.; Brostow, W.; Castano, V. M. J. Mater. Sci. Mater. Med. 2001, 12, 305-311. 
[415]Hosoi, K.; Hashida, T.; Takahashi, H.; Yamasaki, N.; Korenaga, T. J. Am. Ceram. Soc. 1996, 79, 2771-2774.

[416]Walsh, D.; Hopwood, J. D.; Mann, S. Science 1994, 264, 15761578.

[417]Walsh, D.; Mann, S. Chem. Mater. 1996, 8, 1944-1953.

[418] Charriere, E.; Lemaitre, J.; Zysset, P. Biomaterials 2003, 24, 809-817.

[419]Zhao, K.; Tang, Y. F.; Qin, Y. S.; Wei, J. Q. Ceram. Int. 2011, 37, 635-639.

[420]Eichenseer, C.; Will, J.; Rampf, M.; Wend, S.; Greil, P. J. Mater. Sci. Mater. Med. 2010, 21, 131-137.

[421]Zhou, L.; Wang, D.; Huang, W.; Yao, A.; Kamitakahara, M.; Ioku, K. J. Ceram. Soc. Jpn. 2009, 117, 521-524.

[422] Moroni, L.; de Wijn, J. R.; van Blitterswijk, C. A. J. Biomater. Sci. Polymer Edn. 2008, 19, 543-572.

[423] Aizawa, M.; Scott Howell, F.; Itatani, K.; Yokogawa, Y.; Nishizawa, K.; Toriyama, M.; Kameyama, T. J. Ceram. Soc. Jpn. 2000, 108, 249-253.

[424] Kawata, M.; Uchida, H.; Itatani, K.; Okada, I.; Koda, S.; Aizawa, M. J. Mater. Sci. Mater. Med. 2004, 15, 817-823.

[425]Li, S. H.; de Wijn, J. R.; Layrolle, P.; de Groot, K. J. Am. Ceram. Soc. 2003, 86, 65-72.

[426] Koh, Y. H.; Kim, H. W.; Kim, H. E.; Halloran, J. W. J. Am. Ceram. Soc. 2002, 85, 2578-2580.

[427]Nakahira, A.; Tamai, M.; Sakamoto, K.; Yamaguchi, S. J. Ceram. Soc. Jpn. 2000, 108, 99-104.

[428] de Sousa, F. C. G.; Evans, J. R. G. Adv. Appl. Ceram. 2005, 104, 30-34.

[429] Kitamura, M.; Ohtsuki, C.; Ogata, S. I.; Kamitakahara, M.; Tanihara, M.; Miyazaki, T. J. Am. Ceram. Soc. 2005, 88, 822826.

[430] Walsh, D.; Boanini, E.; Tanaka, J.; Mann, S. J. Mater. Chem. 2005, 15, 1043-1048.

[431] Gonzalez-McQuire, R.; Green, D.; Walsh, D.; Hall, S.; ChaneChing, J. Y.; Oreffo, R. O. C.; Mann, S. Biomaterials 2005, 26, 6652-6656.

[432]Ioku, K.; Kawachi, G.; Nakahara, K.; Ishida, E. H.; Minagi, H.; Okuda, T.; Yonezawa, I.; Kurosawa, H.; Ikeda, T. Key Eng. Mater. 2006, 309-311, 1059-1062.

[433] Kitamura, M.; Ohtsuki, C.; Ogata, S.; Kamitakahara, M.; Tanihara, M. Mater. Transact. 2004, 45, 983-988.

[434] Sohier, J.; Daculsi, G.; Sourice, S.; de Groot, K.; Layrolle, P. J. Biomed. Mater. Res. A 2010, 92A, 1105-1114.

[435]Stähli, C.; Bohner, M.; Bashoor-Zadeh, M.; Doebelin, N.; Baroud, G. Acta Biomater. 2010, 6, 2760-2772.

[436]Ramay, H. R.; Zhang, M. Biomaterials 2003, 24, 3293-3302.

[437]Potoczek, M.; Zima, A.; Paszkiewicz, Z.; Ślósarczyk, A. Ceram. Int. 2009, 35, 2249-2254.

[438] Xu, S.; Li, D.; Lu, B.; Tang, Y.; Wang, C.; Wang, Z. Rapid Prototyping J. 2007, 13, 99-106.

[439]Li, S. H.; de Wijn J. R.; Layrolle, P.; de Groot, K. J. Biomed. Mater. Res. 2002, 61, 109-120.
[440] Almirall, A.; Larrecq, G.; Delgado, J. A.; Martínez, S.; Planell, J. A.; Ginebra, M. P. Biomaterials 2004, 25, 3671-3680.

[441] Kamitakahara, M.; Ohtsuki, C.; Kawachi, G.; Wang, D.; Ioku, K. J. Ceram. Soc. Jpn. 2008, 116, 6-9.

[442]Peña, J.; Román, J.; Cabañas, M. V.; Vallet-Regí, M. Acta Biomater. 2010, 6, 1288-1296.

[443] Marcassoli, P.; Cabrini, M.; Tirillò, J.; Bartuli, C.; Palmero, P.; Montanaro, L. Key Eng. Mater. 2010, 417-418, 565-568.

[444] Nakamura, S.; Nakahira, A. J. Ceram. Soc. Jpn. 2008, 116, $42-$ 45.

[445] Song, H. Y.; Islam, S.; Lee, B. T. J. Am. Ceram. Soc. 2008, 91, 3125-3127.

[446]Impens, S.; Schelstraete, R.; Luyten, J.; Mullens, S.; Thijs, I.; van Humbeeck, J.; Schrooten, J. Adv. Appl. Ceram. 2009, 108, 494-500.

[447] Kawachi, G.; Misumi, H.; Fujimori, H.; Goto, S.; Ohtsuki, C.; Kamitakahara, M.; Ioku, K. J. Ceram. Soc. Jpn. 2010, 118, 559563.

[448]Ng, S.; Guo, J.; Ma, J.; Loo, S. C. J. Acta Biomater. 2010, 6, 3772-3781.

[449]Zhao, K.; Tang, Y. F.; Qin, Y. S.; Luo, D. F. J. Eur. Ceram. Soc. 2011, 31, 225-229.

[450] Sakamoto, M.; Nakasu, M.; Matsumoto, T.; Okihana, H. J. Biomed. Mater. Res. A 2007, 82A, 238-242.

[451] Sakamoto, M. J. Ceram. Soc. Jpn. 2010, 118, 753-757.

[452] von Doernberg, M. C.; von Rechenberg, B.; Bohner, M.; Grünenfelder, S.; van Lenthe, G. H.; Müller, R.; Gasser, B.; Mathys, R.; Baroud, G.; Auer, J. Biomaterials 2006, 27, 51865198.

[453]Mygind, T.; Stiehler, M.; Baatrup, A.; Li, H.; Zou, X.; Flyvbjerg, A.; Kassem, M.; Bunger, C. Biomaterials 2007, 28, 1036-1047.

[454]Tsuruga, E.; Takita, H.; Wakisaka, Y.; Kuboki, Y. J. Biochem. 1997, 121, 317-324.

[455]Hing, K.; Annaz, B.; Saeed, S.; Revell, P.; Buckland, T. J. Mater. Sci. Mater. Med. 2005, 16, 467-475.

[456] Woodard, J. R.; Hilldore, A. J.; Lan, S. K.; Park, C. J.; Morgan, A. W.; Eurell, J. A. C.; Clark, S. G.; Wheeler, M. B.; Jamison, R. D.; Wagoner, J. A. J. Biomaterials 2007, 28, 45-54.

[457]Lan Levengood, S. K.; Polak, S. J.; Wheeler, M. B.; Maki, A. J.; Clark, S. G.; Jamison, R. D.; Wagoner Johnson, A. J. Biomaterials 2010, 31, 3552-3563.

[458]Ruksudjarit, A.; Pengpat, K.; Rujijanagul, G.; Tunkasiri, T. Adv. Mater. Res. 2008, 47-50, Part 2, 797-800.

[459]LeGeros, R. Z. Chem. Rev. 2008, 108, 4742-4753.

[460]Prokopiev, O.; Sevostianov, I. Mater. Sci. Eng. A 2006, 431, 218-227.

[461]Daculsi, G.; Jegoux F.; Layrolle, P. The micro macroporous biphasic calcium phosphate concept for bone reconstruction and tissue engineering. In: Advanced Biomaterials: Fundamentals, Processing and Applications. Basu, B.; Katti, D. S.; Kumar, A. Eds.Wiley-American Ceramic Society, 2009, 768 pp. 
[462]Tadic, D.; Beckmann, F.; Schwarz, K.; Epple, M. Biomaterials 2004, $25,3335-3340$.

[463] Woyansky, J. S.; Scott, C. E.; Minnear, W. P. Am. Ceram. Soc. Bull. 1992, 71, 1674-1682.

[464] Vaz, L.; Lopes, A. B.; Almeida, M. J. Mater. Sci. Mater. Med. 1999, 10, 239-242.

[465] Yao, X.; Tan, S.; Jiang, D. J. Mater. Sci. 2005, 40, 4939-4942.

[466]Zhang, J.; Fujiwara, M.; Xu, Q.; Zhu, Y.; Iwasa, M.; Jiang, D. Micropor. Mesopor. Mater. 2008, 111, 411-416.

[467] Simske, S. J.; Ayers R. A.; Bateman T. A. Mater. Sci. Forum 1997, 250, 151-182.

[468] Wang, H.; Zhai, L.; Li, Y.; Shi, T. Mater. Res. Bull. 2008, 43, 1607-1614

[469]Cyster, L. A.; Grant, D. M.; Howdle, S. M.; Rose, F. R. A. J.; Irvine, D. J.; Freeman, D.; Scotchford, C. A.; Shakesheff, K. M. Biomaterials 2005, 26, 697-702.

[470]Tian, J.; Tian, J. J. Mater. Sci. 2001, 36, 3061-3066.

[471]Rodriguez-Lorenzo, L. M.; Vallet-Regí, M.; Ferreira, J. M. F. J. Biomed. Mater. Res. 2002, 60, 232-240.

[472]Lee, E. J.; Koh, Y. H.; Yoon, B. H.; Kim, H. E.; Kim, H. W. Mater. Lett. 2007, 61, 2270-2273.

[473] Jones, J. R.; Hench, L. L. Curr. Opin. Solid State Mater. Sci. 2003, 7, 301-307.

[474]Ota, T.; Eitsuka, T.; Yoshida, H.; Adachi, N. Adv. Mater. Res. 2006, 11-12, 247-250.

[475]Tas, A. C. J. Mater. Sci. Mater. Med. 2008, 19, 2231-2239.

[476]Fu, Q.; Rahaman, M. N.; Dogan, F.; Bal, B. S. J. Biomed. Mater. Res. B (Appl. Biomater.) 2008, 86B, 125-135.

[477]Tang, Y. J.; Tang, Y. F.; Lv, C. T.; Zhou, Z. H. Appl. Surf. Sci. 2008, 254, 5359-5362.

[478]Fan, J.; Lei, J.; Yu, C.; Tu, B.; Zhao, D. Mater. Chem. Phys. 2007, 103, 489-493.

[479] Sopyan, I.; Mel, M.; Ramesh, S.; Khalid, K. A. Sci. Technol. Adv. Mater. 2007, 8, 116-123.

[480]Rice, R. W. Porosity of ceramics. Marcel Dekker, New York, NY, USA, 1998, $560 \mathrm{pp}$.

[481]Fu, Y. C.; Ho, M. L.; Wu, S. C.; Hsieh, H. S.; Wang, C. K. Mater. Sci. Eng. C 2008, 28, 1149-1158.

[482]Hsu, Y. H.; Turner, I. G.; Miles, A. W. J. Mater. Sci. Mater. Med. 2007, 18, 2251-2256.

[483]Munch, E.; Franco, J.; Deville, S.; Hunger, P.; Saiz, E.; Tomsia, A. P. JOM 2008, 60, 54-59.

[484] Macchetta, A.; Turner, I. G.; Bowen, C. R. Acta Biomater. 2009, 5, 1319-1327.

[485]Deville, S.; Saiz, E.; Tomsia, A. P. Biomaterials 2006, 27, 54805489.

[486]Zuo, K. H.; Zeng, Y. P.; Jiang, D. Mater. Sci. Eng. C 2010, 30, 283-287.

[487]Ginebra, M. P.; Espanol, M.; Montufar, E. B.; Perez, R. A.; Mestres, G. Acta Biomater. 2010, 6, 2863-2873.

[488] Yun, H. S. Key Eng. Mater. 2010, 441, 139-153.

[489]Deisinger, U. Key Eng. Mater. 2010, 441, 155-179.
[490] Yan, X.; Yu, C.; Zhou, X.; Tang, J.; Zhao, D. Angew. Chem. Int. Ed. Engl. 2004, 43, 5980-5984.

[491] Izquierdo-Barba, I.; Ruiz-González, L.; Doadrio, J. C.; González-Calbet, J. M.; Vallet-Regí, M. Solid State Sci. 2005, 7, 983-989.

[492] Cosijns, A.; Vervaet, C.; Luyten, J.; Mullens, S.; Siepmann, F.; van Hoorebeke, L.; Masschaele, B.; Cnudde, V.; Remon, J. P. Eur. J. Pharm. Biopharm. 2007, 67, 498-506.

[493]Uchida, A.; Shinto, Y.; Araki, N.; Ono, K. J. Orthop. Res. 1992, 10, 440-445.

[494]Shinto, Y.; Uchida, A.; Korkusuz, F.; Araki, N.; Ono, K. J. Bone. Joint. Surg. Br. 1992, 74, 600-604.

[495]Martin, R. B.; Chapman, M. W.; Sharkey, N. A.; Zissimos, S. L.; Bay, B.; Shors, E. C. Biomaterials 1993, 14, 341-348.

[496] Kazakia, G. J.; Nauman, E. A.; Ebenstein, D. M.; Halloran, B. P.; Keaveny, T. M. J. Biomed. Mater. Res. A 2006, 77A, 688699.

[497]Hing, K. A.; Best, S. M.; Tanner, K. E.; Bonfield, W.; Revell, P. A. J. Biomed. Mater. Res. A 2004, 68A, 187-200.

[498] Vuola, J.; Taurio, R.; Goransson, H.; Asko-Seljavaara, S. Biomaterials 1998, 19, 223-227.

[499] Yang, L.; Ning, X.; Chen, K.; Zhou, H. Ceram. Int. 2007, 33, 483-489.

[500]Levitt, G. E; Crayton, P. H.; Monroe, E. A.; Condrate, R. A. J. Biomed. Mater. Res. 1969, 3, 683-685.

[501]Tadic, D.; Epple, M. Biomaterials 2004, 25, 987-994.

[502]Bodde, E. W. H.; Wolke, J. G. C.; Kowalski, R. S. Z.; Jansen, J. A. J. Biomed. Mater. Res. A 2007, 82A, 711-722.

[503]le Guéhennec, L.; Layrolle, P.; Daculsi, G. Eur. Cell Mater. 2004, 8, 1-11.

[504]LeGeros, R. Z. Clin. Orthop. Rel. Res. 2002, 395, 81-98.

[505]Kashimura, H.; Ogasawara, K.; Kubo, Y.; Yoshida, K.; Sugawara, A.; Ogawa, A. Vascular Health and Risk Management 2010, 6, 105-108.

[506]Jordan, D. R.; Gilberg, S.; Bawazeer, A. Ophthal. Plast. Reconstr. Surg. 2004, 20, 69-74.

[507] Yoon, J. S.; Lew, H.; Kim, S. J.; Lee, S. Y. Ophthalmology 2008, 115, 566-572. e2.

[508]Chai, G. R.; Chen, M. Int. J. Ophthal. 2010, 10, 999-1000.

[509] Tabatabaee, Z.; Mazloumi, M.; Rajabi, T. M.; Khalilzadeh, O.; Kassaee, A.; Moghimi, S.; Eftekhar, H.; Goldberg, R. A. Comparison of the exposure rate of wrapped hydroxyapatite (Bio-Eye) versus unwrapped porous polyethylene (Medpor) orbital implants in enucleated patients. Ophthalmic Plastic \& Reconstructive Surgery 2010, (early view).

[510] Yoon, J. S.; Lew, H.; Kim, S. J.; Lee, S. Y. Ophthalmology 2008, 115, 566-572.

[511]Liao, H. F.; Xiao, W.; Chen, Q. J. J. Clin. Rehabil. Tissue Eng. Res. 2008, 12, 8905-8908.

[512] Schnettler, R.; Stahl, J. P.; Alt, V.; Pavlidis, T.; Dingeldein, E.; Wenisch, S. Eur. J. Trauma 2004, 4, 219-229. 
[513]Zyman, Z. Z.; Glushko, V.; Dedukh, N.; Malyshkina, S.; Ashukina, N. J. Mater. Sci. Mater. Med. 2008, 19, 2197-2205.

[514]Constantz, B. R.; Ison, I. C.; Fulmer, M. T.; Poser, R. D.; Smith, S. T.; Vanwagoner, M.; Ross, J.; Goldstein, S. A.; Jupiter, J. B.; Rosenthal, D. I. Science 1995, 267, 1796-1799.

[515]Dorozhkin, S. V. J. Mater. Sci. 2008, 43, 3028-3057.

[516]Dorozhkin, S. V. Materials 2009, 2, 221-291.

[517]Chow, L. C. Dent. Mater. J. 2009, 28, 1-10.

[518] del Real, R. P.; Wolke, J. G. C.; Vallet-Regí, M.; Jansen, J. A. Biomaterials 2002, 23, 3673-3680.

[519] Victor, S. P.; Kumar, T. S. S. J. Ceram. Soc. Jpn. 2008, 116, 105-107.

[520]Hesaraki, S.; Nemati, R.; Nosoudi, N. Adv. Appl. Ceram. 2009, 108, 231-240.

[521]Weiss, D. D.; Sachs, M. A.; Woodard, C. R. J. Long Term Eff. Med. Implants 2003, 13, 41-47.

[522] Ambard, A. J.; Mueninghoff, L. J. Prosthodont. 2006, 15, 321328.

[523] Costantino, P. D.; Friedman, C. D.; Jones, K.; Chow, L. C.; Pelzer, H. J.; Sisson, G. A. Arch. Otolaryngol. Head Neck Surg. 1991, 117, 379-384.

[524]Costantino, P. D.; Friedman, C. D.; Jones, K.; Chow, L. C.; Pelzer, H. J.; Sisson, G. A. Arch. Otolaryngol. Head Neck Surg. 1991, 117, 385-389.

[525]Ong, J. L.; Chan, D. C. N. Crit. Rev. Biomed. Eng. 1999, 28, 667-707.

[526] de Groot, K.; Wolke, J. G. C.; Jansen, J. A. Proc. Inst. Mech. Eng. Part H: J. Eng. Med. 1998, 212, 137-147.

[527]Campbell, A. A. Mater. Today 2003, 6, 26-30.

[528]Epinette, J. A. M. D.; Geesink, R. G. T. Hydroxyapatite coated hip and knee arthroplasty. Elsevier, Amsterdam, Netherlands. 1995; 394 pp.

[529] Willmann, G. Adv. Eng. Mater. 1999, 1, 95-105.

[530] Schliephake, H.; Scharnweber, D.; Roesseler, S.; Dard, M.; Sewing, A.; Aref, A. Int. J. Oral Max. Impl. 2006, 21, 738-746.

[531] Kokubo, T.; Kim, H. M.; Kawashita, M. Biomaterials 2003, 24 , 2161-2175.

[532]Habibovic, P.; Li, J.; van der Valk, C. M.; Meijer, G.; Layrolle, P.; van Blitterswijk, C. A.; de Groot, K. Biomaterials 2005, 26, 23-36.

[533]Hahn, B. D.; Park, D. S.; Choi, J. J.; Ryu, J.; Yoon, W. H.; Kim, K. H.; Park, C.; Kim, H. E. J. Am. Ceram. Soc. 2009, 92, 683687.

[534] Gineste, L.; Gineste, M.; Ranz, X.; Ellefterion, A.; Guilhem, A.; Rouquet, N.; Frayssinet, P. J. Biomed. Mater. Res. 1999, 48, 224-234.

[535] Okada, M.; Furuzono, T. Mater. Sci. Eng. B 2010, 173, 199-203.

[536]Xiao, Y.; Gong, T.; Zhou, S. Biomaterials 2010, 31, 5182-5190.

[537]Habibovic, P.; Barrère, F.; van Blitterswijk, C. A.; de Groot, K.; Layrolle, P. J. Am. Ceram. Soc. 2002, 85, 517-522.

[538]Sun, L.; Berndt, C. C.; Gross, K. A.; Kucuk, A. J. Biomed. Mater. Res. (Appl. Biomater.) 2001, 58, 570-592.
[539] Yang, Y.; Kim, K. H.; Ong, J. L. Biomaterials 2005, 26, $327-$ 337.

[540] Oliveira, A. L.; Mano, J. F.; Reis, R. L. Curr. Opin. Solid State Mater. Sci. 2003, 7, 309-318.

[541]Manso, M.; Jiménez, C.; Morant, C.; Herrero, P.; MartínezDuart, J. Biomaterials 2000, 21, 1755-1761.

[542] Kuo, M. C.; Yen, S. K. Mater. Sci. Eng. C 2002, 20, 153-160.

[543]Eliaz, N.; Sridhar, T. M.; Mudali, U. K.; Raj, B. Surf. Eng. 2005, 21, 238-242.

[544]Ma, M.; Ye, W.; Wang, X. X. Mater. Lett. 2008, 62, 3875-3877.

[545]Ong, J. L.; Appleford, M.; Oh, S.; Yang, Y.; Chen, W. H.; Bumgardner, J. D.; Haggard, W. O. JOM 2006, 58, 67-69.

[546]Qu, H.; Wei, M. J. Biomed. Mater. Res. B (Appl. Biomater.) 2008, 87B, 204-212.

[547]Esfehanian, M.; Raissi-Dehkordi, B.; Moztarzadeh, F. InterCeram 2005, 54, 92-98.

[548]Narayanan, R.; Seshadri, S. K.; Kwon, T. Y.; Kim, K. H. J. Biomed. Mater. Res. B (Appl. Biomater.) 2008, 85B, 279-299.

[549]Sugino, A.; Tsuru, K.; Hayakawa, S.; Kikuta, K.; Kawachi, G.; Osaka, A.; Ohtsuki, C. J. Ceram. Soc. Jpn. 2009, 117, 515-520.

[550] Ye, G.; Troczynski, T. Ceram. Int. 2008, 34, 511-516.

[551]Zheng, M.; Fan, D.; Li, X. K.; Zhang, J. B.; Liu, Q. B. J. Alloys Compounds 2010, 489, 211-214.

[552] Geesink, R. G. T. Clin. Orthop. Related Res. 2002, 395, 53-65.

[553]Mukherjee, D. P.; Dorairaj, N. R.; Mills, D. K.; Graham, D.; Krauser, J. T. J. Biomed. Mater. Res. 2000, 53, 467-474.

[554]Gledhill, H. C.; Turner, I. G.; Doyle, C. Biomaterials 2001, 22, 1233-1240.

[555]Cheng, K.; Ren, C.; Weng, W.; Du, P.; Shen, G.; Han, G.; Zhang, S. Thin Solid Films 2009, 517, 5361-5364.

[556] de Groot, K.; Geesink, R. G. T.; Klein, C. P. A. T.; Serekian, P. J. Biomed. Mater. Res. 1987, 21, 1375-1381.

[557]Furlong, R. J.; Osborn, J. F. J. Bone Joint Surg. B 1991, 73, 741745.

[558] Saithna, A. Injury 2010, 41, 128-132.

[559]Chang, J. K.; Chen, C. H.; Huang, K. Y.; Wang, G. J. J. Arthroplasty 2006, 21, 541-546.

[560] Matsumine, A.; Myoui, A.; Kusuzaki, K.; Araki, N.; Seto, M.; Yoshikawa, H.; Uchida, A. J. Bone Joint Surg. B 2004, 86, 719725.

[561] Muirhead-Allwood, S. K.; Sandiford, N.; Skinner, J. A.; Hua, J.; Kabir, C.; Walker, P. S. J. Bone Joint Surg. B 2010, 92, 10791084.

[562] Shetty, A. A.; Slack, R.; Tindall, A.; James, K. D.; Rand, C. J. Bone Joint Surg. B 2005, 87, 1050-1054.

[563]Buchanan, J. M. Key Eng. Mater. 2005, 284-286, 1049-1052.

[564]Buchanan, J. M. Key Eng. Mater. 2006, 309-311, 1341-1344.

[565]Buchanan, J. M.; Goodfellow, S. Key Eng. Mater. 2008, 361 $363,1315-1318$.

[566]Rajaratnam, S. S.; Jack, C.; Tavakkolizadeh, A.; George, M. D.; Fletcher, R. J.; Hankins, M.; Shepperd, J. A. N. J. Bone Joint Surg. B 2008, 90, 27-30.

http://ccaasmag.org/BIO 
[567]Epinette, J. A.; Manley, M. T. (Eds.) Fifteen years of clinical experience with hydroxyapatite coatings in joint arthroplasty. Springer, France, 2004, 452 pp.

[568]Binahmed, A.; Stoykewych, A.; Hussain, A.; Love, B.; Pruthi, V. Int. J. Oral Max. Impl. 2007, 22, 963-968.

[569]Iezzi, G.; Scarano, A.; Petrone, G.; Piattelli, A. J. Periodontol. 2007, 78, 940-947.

[570] Bauer, T. W.; Geesink, R. G. T.; Zimmerman, R.; McMahon, J. T. J. Bone Joint Surg. A 1991, 73, 1439-1452.

[571] Buma, P.; Gardeniers, J. W. J. Arthroplasty 1995, 10, 389-395.

[572] Capello, W. D.; D’Antonio, J. A.; Feinberg, J. R.; Manley, M. T. J. Bone Joint Surg. A 1997, 79, 1023-1029.

[573]Paital, S. R.; Dahotre, N. B. Mater. Sci. Eng. R 2009, 66, 1-70.

[574]León, B.; Jansen, J. A. (Eds.), Thin calcium phosphate coatings for medical implants. Springer, New York, USA, 2009, 326 pp.

[575] To narrow the subject of this review, functionally graded bioceramics prepared from calcium orthophosphates with various dopants is not considered. The interested readers are advised to read the original papers [316, 576, 577].

[576] Manjubala, I.; Kumar, T. S. S. Biomaterials 2000, 21, 19952002.

[577]Wei, T.; Ruys, A.; Milthorpe, B. Key Eng. Mater. 2003, 240 242, 591-594.

[578] Kon, M.; Ishikawa, K.; Miyamoto, Y.; Asaoka, K. Biomaterials 1995, 16, 709-714.

[579]Wong, L. H.; Tio, B.; Miao, X. Mater. Sci. Eng. C 2002, 20, 111-115.

[580] Tampieri, A.; Celotti, G.; Sprio, S.; Delcogliano, A.; Franzese, S. Biomaterials 2001, 22, 1365-1370.

[581]Lu, W. W.; Zhao, F.; Luk, K. D. K.; Yin, Y. J.; Cheung, K. M. C.; Cheng, G. X.; Yao, K. D.; Leong, J. C. Y. J. Mater. Sci. Mater. Med. 2003, 14, 1039-1046.

[582] Werner, J.; Linner-Krcmar, B.; Friess, W.; Greil, P. Biomaterials 2002, 23, 4285-4294.

[583] Kaito, T.; Mukai, Y.; Nishikawa, M.; Ando, W.; Yoshikawa, H.; Myoui, A. J. Biomed. Mater. Res. B (Appl. Biomater.) 2006, 78B, 378-384.

[584]Rodriguez-Lorenzo, L. M.; Ferreira, J. M. F. Mater. Res. Bull. 2004, 39, 83-91.

[585]Lu, W. W.; Zhao, F.; Luk, K. D. K.; Yin, Y. J.; Cheung, K. M. C.; Cheng, G. X.; Yao, K. D.; Leong, J. C. Y. J. Mater. Sci. Mater. Med. 2003, 14, 1039-1046.

[586] Watanabe, T.; Fukuhara, T.; Izui, H.; Fukase, Y.; Okano, M. Transact. Jpn. Soc. Mech. Eng. A 2009, 75, 612-618.

[587]Roy, M.; Balla, V. K.; Bandyopadhyay, A.; Bose, S. Acta Biomater. 2011, 7, 866-873.

[588] Soon, Y. M.; Shin, K. H.; Koh, Y. H.; Lee, J. H.; Choi, W. Y.; Kim, H. E. J. Eur. Ceram. Soc. 2011, 31, 13-18.

[589]Dubok, V. A. Powder Metallurgy and Metal Ceramics 2000, 39, 381-394.

[590]Heness, G.; Ben-Nissan, B. Mater. Forum 2004, 27, 104-114.
[591] Ohtsuki C.; Kamitakahara, M.; Miyazaki, T. J. R. Soc. Interface 2009, 6, S349-S360.

[592] The term "bioinert" should be used with care, since it is clear that any material introduced into the physiological environment will induce a response. However, for the purposes of biomedical implants, the term can be defined as a minimal level of response from the host tissue [5].

[593] Greenspan, D. C. Curr. Opin. Solid State Mater. Sci. 1999, 4, 389-393.

[594]Blokhuis, T. J.; Termaat, M. F.; den Boer, F. C.; Patka, P.; Bakker, F. C.; Haarman, H. J. T. M. J. Trauma 2000, 48, 179189.

[595] Kim, H. M. J. Ceram. Soc. Jpn. 2001, 109, S49-S57.

[596]Seeley, Z.; Bandyopadhyay, A.; Bose, S. Mater. Sci. Eng. C 2008, 28, 11-17.

[597]Descamps, M.; Richart, O.; Hardouin, P.; Hornez. J. C.; Leriche A. Ceram. Int. 2008, 34, 1131-1137.

[598]Cushnie, E. K.; Khan, Y. M.; Laurencin, C. T. J. Biomed. Mater. Res. A 2008, 84A, 54-62.

[599]Hench, L. L. Am. Ceram. Soc. Bull. 2005, 84, 18-21.

[600] Nagase, M.; Baker, D. G.; Schumacher, H. R. J. Rheumatology 1988, 15, 1334-1338.

[601] Rooney, T.; Berman, S.; Indersano, A. T. J. Oral Maxillofac. Surg. 1988, 46, 15-18.

[602] Prudhommeaux, F.; Schiltz, C.; Lioté, F.; Hina, A.; Champy, R.; Bucki, B.; Ortiz-Bravo, E.; Meunier, A.; Rey, C.; Bardin, T. Arthritis and Rheumatism 1996, 39, 1319-1326.

[603]Uchida, A.; Araki, N.; Shinto, Y.; Yoshikawa, H.; Kurisaki, E.; Ono, K. J. Bone Joint Surg. B 1990, 72, 298-302.

[604] Osteogenesis is the process of laying down new bone material by osteoblasts.

[605] Osteoinduction is the property of the material to induce bone formation de novo or ectopically (i. e.; in non-bone forming sites). It happens due to a stimulation and activation of host mesenchymal stem cells from the surrounding tissues, which differentiate into bone-forming osteoblasts [606].

[606] Giannoudis P. V.; Dinopoulos, H.; Tsiridis, E. Injury 2005, 36, Suppl. 1, S20-S27.

[607] Osteoid is a bioorganic portion of the matrix of bone tissue. Osteoblasts begin the process of forming bone tissue by secreting the osteoid as several specific proteins. When the osteoid becomes mineralized, it and the adjacent bone cells have developed into new bone tissues.

[608] Yamasaki, H.; Sakai, H. Biomaterials 1992, 13, 308-312.

[609]Klein, C.; de Groot, K.; Chen, W.; Li, Y.; Zhang, X. Biomaterials 1994, 15, 31-34.

[610] Yuan, H.; Yang, Z.; Li, Y.; Zhang, Z.; de Bruijn, J. D.; de Groot, K. J. Mater. Sci. Mater. Med. 1998, 9, 723-726.

[611]Ripamonti, U. Biomaterials 1996, 17, 31-35.

[612]Ripamonti, U.; Crooks, J.; Kirkbride, A. N. South African J. Sci. 1999, 95, 335-343. 
[613] Yuan, H. P.; de Bruijn, J. D.; Li, Y. B.; Feng, J. Q.; Yang, Z. J.; de Groot, K.; Zhang, X. D. J. Mater. Sci. Mater. Med. 2001, 12, 7-13.

[614] Matsushita, N.; Terai, H.; Okada, T.; Nozaki, K.; Inoue, H.; Miyamoto, S.; Takaoka, K. J. Biomed. Mater. Res. A 2004, 70A, 450-458.

[615] le Nihouannen, D.; Daculsi, G.; Saffarzadeh, A.; Gauthier, O.; Delplace, S.; Pilet, P.; Layrolle, P. Bone 2005, 36, 1086-1093.

[616] Yuan, H.; Kurashina, K.; de Bruijn, D. J.; Li, Y.; de Groot, K.; Zhang, X. Biomaterials 1999, 20, 1799-1806.

[617]Gosain, A. K.; Song, L.; Riordan, P.; Amarante, M. T.; Nagy, P. G.; Wilson, C. R.; Toth, J. M.; Ricci, J. L. Plast. Reconstr. Surg. 2002, 109, 619-630.

[618]Cheng, L.; Ye, F.; Yang, R.; Lu, X.; Shi, Y.; Li, L.; Fan, H.; Bu, H. Acta Biomater. 2010, 6, 1569-1574.

[619]Barrere, F.; van der Valk, C. M.; Dalmeijer, R. A.; Meijer, G.; van Blitterswijk, C. A.; de Groot, K.; Layrolle, P. J. Biomed. Mater. Res. A 2003, 66A, 779-788.

[620]Habibovic, P.; van der Valk, C. M.; van Blitterswijk, C. A.; de Groot, K.; Meijer, G. J. Mater. Sci. Mater. Med. 2004, 15, 373380.

[621]Yuan, H.; Fernandes, H.; Habibovic, P.; de Boer J.; Barradas, A. M. C.; de Ruiter, A.; Walsh, W. R.; van Blitterswijk, C. A.; de Bruijn, J. D. Proc. Natl. Acad. Sci. USA 2010, 107, 1361413619.

[622]Habibovic, P.; Yuan, H.; van der Valk, C. M.; Meijer, G.; van Blitterswijk, C. A.; de Groot, K. Biomaterials 2005, 26, 35653575.

[623]Habibovic, P.; Sees, T. M.; van den Doel, M. A.; van Blitterswijk, C. A.; de Groot, K. J. Biomed. Mater. Res. A 2006 , 77A, 747-762.

[624]Reddi, A. H. Tissue Eng. 2000, 6, 351-359.

[625]Ripamonti, U. J. Bone Joint Surg. A 1991, 73, 692-703.

[626] Kuboki, Y.; Takita, H.; Kobayashi, D. J. Biomed. Mater. Res. 1998, 39, 190-199.

[627]Diaz-Flores, L.; Gutierrez, R.; Lopez-Alonso, A.; Gonzalez, R.; Varela, H. Clin. Orthop. Relat. Res. 1992, 275, 280-286.

[628] Dorozhkin, S. V. Comment Inorg. Chem. 1999, 20, 285-299.

[629]Dorozhkin, S. V. Prog. Cryst. Growth Charact. 2002, 44, 45-61.

[630]Muller-Mai, C. M.; Voigt, C.; Gross, U. Scan. Microscopy 1990, $4,613-624$.

[631]Wenisch, S.; Stahl, J. P.; Horas, U.; Heiss, C.; Kilian, O.; Trinkaus, K.; Hild, A.; Schnettler, R. J. Biomed. Mater. Res. A 2003, 67A, 713-718.

[632]Riihonen, R.; Nielsen, S.; Väänänen, H. K.; Laitala-Leinonen, T.; Kwon, T. H. Matrix Biol. 2010, 29, 287-294.

[633] Teitelbaum, S. L. Science 2000, 289, 1504-1508.

[634]Okuda, T.; Ioku, K.; Yonezawa, I.; Minagi, H.; Kawachi, G.; Gonda, Y.; Murayama, H.; Shibata, Y.; Minami, S.; Kamihara, S.; Kurosawa, H.; Ikeda, T. Biomaterials 2007, 28, 2612-2621.

[635] Orly, I.; Gregoire, M.; Menanteau, J.; Heughebaert, M.; Kerebel, B. Calcif. Tissue Int. 1989, 45, 20-26.
[636]Bertazzo, S.; Zambuzzi, W. F.; Campos, D. D. P.; Ogeda, T. L.; Ferreira, C. V.; Bertran, C. A. Colloids Surf. B 2010, 78, 177184.

[637] Schwartz, Z.; Boyan, B. D. J. Cell. Biochem. 1994, 56, 340-347. [638]Puleo, D. A.; Nanci, A. Biomaterials 1999, 20, 2311-2321.

[639]Xin, R.; Leng, Y.; Chen, J.; Zhang, Q. Biomaterials 2005, 26, 6477-6486.

[640]Girija, E. K.; Parthiban, S. P.; Suganthi, R. V.; Elayaraja, K.; Joshy, M. I. A.; Vani, R.; Kularia, P.; Asokan, K.; Kanjilal, D.; Yokogawa, Y.; Narayana Kalkura, S. J. Ceram. Soc. Jpn. 2008, 116, 320-324.

[641]Okada, M.; Furukawa, K.; Serizawa, T.; Yanagisawa, Y.; Tanaka, H.; Kawai, T.; Furuzono, T. Langmuir 2009, 25, 63006306.

[642]Malik, M. A.; Puleo, D. A.; Bizios, R.; Doremus, R. H. Biomaterials 1992, 13, 123-128.

[643]Norman, M. E.; Elgendy, H. M.; Shors, E. C.; El-Amin, S. F.; Laurencin, C. T. Clin. Mater. 1994, 17, 85-91.

[644]Shu, R.; McMullen, R.; Baumann, M. J.; McCabe, L. R. J. Biomed. Mater. Res. A 2003, 67A, 1196-1204.

[645] Gomi, K.; Lowenberg, B.; Shapiro, G.; Davies, J. E. Biomaterials 1992, 20, 91-96.

[646]Suzuki, T.; Ohashi, R.; Yokogawa, Y.; Nishizawa, K.; Nagata, F.; Kawamoto, Y.; Kameyama, T.; Toriyama, M. J. Biosci. Bioeng. 1999, 87, 320-327.

[647] Arinzeh, T. L.; Tran, T.; McAlary, J.; Daculsi, G. Biomaterials 2005, 26, 3631-3638.

[648]Oh, S.; Oh, N.; Appleford, M.; Ong, J. L. Am. J. Biochem. Biotechnol. 2006, 2, 49-56.

[649] Appleford, M.; Oh, S.; Cole, J. A.; Carnes, D. L.; Lee, M.; Bumgardner, J. D.; Haggard, W. O.; Ong, J. L. Biomaterials 2007, 28, 2747-2753.

[650] Ghanaati, S.; Barbeck, M.; Orth, C.; Willershausen, I.; Thimm, B. W.; Hoffmann, C.; Rasic, A.; Sader, R. A.; Unger, R. E.; Peters, F.; Kirkpatrick, C. J. Acta Biomater. 2010, 6, 4476-4487.

[651] Ohgushi, H.; Caplan, A. I. J. Biomed. Mater. Res. 1999, 48, $913-$ 927.

[652] Okumura, M.; Ohgushi, H.; Tamai, S. Biomaterials 1990, 12, 28-37.

[653]Unger, R. E.; Sartoris, A.; Peters, K.; Motta, A.; Migliaresi, C.; Kunkel, M.; Bulnheim, U.; Rychly, J.; Kirkpatrick, C. J. Biomaterials 2007, 28, 3965-3976.

[654]Saiz, E.; Gremillard, L.; Menendez, G.; Miranda, P.; Gryn, K.; Tomsia, A. P. Mater. Sci. Eng. C 2007, 27, 546-550.

[655]Tamai, N.; Myoui, A.; Hirao, M.; Kaito, T.; Ochi, T.; Tanaka, J.; Takaoka, K.; Yoshikawa, H. Osteoarthritis Cartilage 2005, 13, 405-417.

[656]Bignon, A.; Chouteau, J.; Chevalier, J.; Fantozzi, G.; Carret, J. P.; Chavassieux, P.; Boivin, G.; Melin, M.; Hartmann, D. J. Mater. Sci. Mater. Med. 2003, 14, 1089-1097.

[657] Griffith, L. G.; Naughton, G. Science 2002, 295, 1009-1014. 
[658]van Blitterswijk, C. A.; Thomsen, P.; Hubbell, J.; Cancedda R.; de Bruijn, J. D.; Lindahl, A.; Sohier, J.; Williams, D. F.; (Eds.), Tissue engineering. Academic Press, Burlington, MA, USA, 2008, 760 pp.

[659]Repair is usually a rapid occurrence that is required for the survival of the individual but is not necessary for its optimal function. It usually results in a dense connective tissue scar that fills the space; however, it may not be responsive to the highly loaded mechanical environment required of musculoskeletal tissue. Regeneration is a slow process that is usually characterized by the recapitulation of aspects of embryonic development [660].

[660] Goldberg, V. M.; Caplan, A. I. Orthopedic tissue engineering basic science and practice. Marcel Dekker, New York, USA, 2004, 338 pp.

[661] In 2003, the NSF published a report titled: "The emergence of tissue engineering as a research field", which provides a thorough description of the history of this field. See: http://www. nsf. gov/pubs/2004/nsf0450/start. htm (accessed in January 2011).

[662] Ikada, Y. J. R. Soc. Interface 2006, 3, 589-601.

[663]Cima, L. G.; Langer, R. Chem. Eng. Prog. 1993, 89, 46-54.

[664]Langer, R.; Vacanti, J. P. Science 1993, 260, 920-926.

[665]El-Ghannam, A. Expert Rev. Med. Dev. 2005, 2, 87-101.

[666] In general, a scaffold is a temporary structure used to support people and material in the construction or repair of buildings and other large structures. It is usually a modular system of metal pipes (termed tubes in Britain), although it can be made out of other materials.

[667] Yang, S.; Leong, K. F.; Du, Z.; Chua, C. K. Tissue Eng. 2001, 7, 679-689.

[668] Hutmacher, D. W. Biomaterials 2000, 21, 2529-2543.

[669] Ma, P. X. Mater. Today 2004, 7, 30-40.

[670] Yasuhiko, T. J. R. Soc. Interface 2009, 6, S311-S324.

[671] Ma, P. X.; Elisseeff, J. (Eds.) Scaffolding in tissue engineering. CRC Press, Boca Raton, FL, USA, 2006, 638 pp.

[672] Schieker, M.; Seitz, H.; Drosse, I.; Seitz, S.; Mutschler, W. Eur. J. Trauma 2006, 32, 114-124.

[673] Okumura, M.; Ohgushi, H.; Dohi, Y.; Katuda, T.; Tamai, S.; Koerten, H. K.; Tabata, S. J. Biomed. Mater. Res. 1997, 37, 122129.

[674] Service, R. F. Science 2000, 289, 1498-1500.

[675]Fini, M.; Giardino, R.; Borsari, V.; Torricelli, P.; Rimondini, L.; Giavaresi, G.; Aldini, N. N. Int. J. Artif. Organs 2003, 26, 520528.

[676] Sato, M.; Webster, T. J. Nanomedicine 2006, 1, 351-354.

[677]Annaz, B.; Hing, K. A.; Kayser, M.; Buckland, T.; di Silvio, L. J. Microscopy 2004, 216, 97-109.

[678]Li, S.; de Wijn, J. R.; Li, J.; Layrolle, P.; de Groot, K. Tissue Eng. 2003, 9, 535-548.

[679]Ebaretonbofa, E.; Evans, J. R. J. Porous Mater. 2002, 9, 257 263.
[680] Specchia, N.; Pagnotta, A.; Cappella, M.; Tampieri, A.; Greco, F. J. Mater. Sci. 2002, 37, 577-584.

[681] Malmström, J.; Adolfsson, E.; Arvidsson, A.; Thomsen, P. Clin. Implant Dentistry Rel. Res. 2007, 9, 79-88.

[682]Teixeira, C. C.; Nemelivsky, Y.; Karkia, C.; LeGeros, R. Z. Tissue Eng. 2006, 12, 2283-2289.

[683]Teixeira, S.; Oliveira, S.; Ferraz, M. P.; Monteiro, F. J. Key Eng. Mater. 2008, 361-363, 947-950.

[684]Peng, Q.; Jiang, F.; Huang, P.; Zhou, S.; Weng, J.; Bao, C.; Zhang, C.; Yu, H. J. Biomed. Mater. Res. A 2010, 93A, 920-929.

[685] Stevens, M. M. Mater. Today 2008, 11, 18-25.

[686] Artzi, Z.; Weinreb, M.; Givol, N.; Rohrer, M. D.; Nemcovsky, C. E.; Prasad, H. S.; Tal, H. Int. J. Oral Max. Impl. 2004, 19, 357-368.

[687]Burg, K. J. L.; Porter, S.; Kellam, J. F. Biomaterials 2000, 21, 2347-2359.

[688] Ajaal, T. T.; Smith, R. W. J. Mater. Process. Technol. 2009, 209, 1521-1532.

[689]Boyde, A.; Corsi, A.; Quarto, R.; Cancedda, R.; Bianco, P. Bone 1999, 24, 579-589.

[690]Hing, K. A. Int. J. Appl. Ceram. Technol. 2005, 2, 184-199.

[691]Peppas, N. A.; Langer, R. Science 1994, 263, 1715-1720.

[692]Hench, L. L. Biomaterials 1998, 19, 1419-1423.

[693]Barrère, F.; Mahmood, T. A.; de Groot, K.; van Blitterswijk, C. A. Mater. Sci. Eng. R 2008, 59, 38-71.

[694]Dellinger, J. G.; Eurell, J. A. C.; Jamison, R. D. J. Biomed. Mater. Res. A 2006, 76A, 366-376.

[695]Pal, K.; Pal, S. Mater. Manuf. Process. 2006, 21, 325-328.

[696]Bae, C. J.; Kim, H. W.; Koh, Y. H.; Kim, H. E. J. Mater. Sci. Mater. Med. 2006, 17, 517-521.

[697]Guo, H.; Wei, J.; Kong, H.; Liu, C.; Pan, K. Adv. Mater. Res. 2008, 47-50, Part 2, 1383-1386.

[698]Guo, H.; Su, J.; Wei, J.; Kong, H.; Liu, C. Acta Biomater. 2009, $5,268-278$.

[699]Wilson, C. E.; van Blitterswijk, C. A.; Verbout, A. J.; Dhert, W. J. A.; de Bruijn, J. D. J. Mater. Sci. Mater. Med. 2011, 22, 97 105.

[700] Schumacher, M.; Deisinger, U.; Detsch, R.; Ziegler, G. J. Mater. Sci. Mater. Med. 2010, 21, 3119-3127.

[701]Liu, H.; Webster, T. J. Biomaterials 2007, 28, 354-369.

[702]Wang, C.; Duan, Y.; Markovic, B.; Barbara, J.; Howlett, C. R.; Zhang, X.; Zreiqat, H. Biomaterials 2004, 25, 2949-2956.

[703] Matsumoto, T.; Okazaki, M.; Nakahira, A.; Sasaki, J.; Egusa, H.; Sohmura, T. Curr. Med. Chem. 2007, 14, 2726-2733.

[704]Traykova, T.; Aparicio, C.; Ginebra, M. P.; Planell, J. A. Nanomedicine 2006, 1, 91-106.

[705] Kalita, S. J.; Bhardwaj, A.; Bhatt, H. A. Mater. Sci. Eng. C 2007, 27, 441-449.

[706]Dorozhkin, S. V. J. Biomimetics Biomaterials Tissue Eng. 2009, 3, 59-92.

[707]Dorozhkin, S. V. Materials 2009, 2, 1975-2045.

[708]Dorozhkin, S. V. Acta Biomater. 2010, 6, 715-734. 
[709] Aizawa, M.; Porter, A. E.; Best, S. M.; Bonfield, W. Biomaterials 2005, 26, 3427-3433.

[710]Park, Y. M.; Ryu, S. C.; Yoon, S. Y.; Stevens, R.; Park, H. C. Mater. Chem. Phys. 2008, 109, 440-447.

[711] Morisue, H.; Matsumoto, M.; Chiba, K.; Matsumoto, H.; Toyama, Y.; Aizawa, M.; Kanzawa, N.; Fujimi, T. J.; Uchida, H.; Okada, I. Spine 2006, 31, 1194-1200.

[712] Matsuda, A.; Ikoma, T.; Kobayashi, H.; Tanaka, J. Mater. Sci. Eng. C 2004, 24, 723-728.

[713]Tas, A. C. J. Am. Ceram. Soc. 2001, 84, 295-300.

[714] Aizawa, M.; Ueno, H.; Itatani, K.; Okada, I. J. Eur. Ceram. Soc. 2006, 26, 501-507.

[715]Wu, Y.; Hench, L. L.; Du, J.; Choy, K. L.; Guo, J. J. Am. Ceram. Soc. 2004, 87, 1988-1991.

[716]Ramanan, S. R.; Venkatesh, R. Mater. Lett. 2004, 58, 33203323.

[717] Seo, D. S.; Lee, J. K. J. Cryst. Growth 2008, 310, 2162-2167.

[718] Tas, A. C. J. Am. Ceram. Soc. 2007, 90, 2358-2362.

[719]Neira, I. S.; Guitián, F.; Taniguchi, T.; Watanabe, T.; Yoshimura, M. J. Mater. Sci. 2008, 43, 2171-2178.

[720] Yang, H. Y.; Yang, S. F.; Chi, X. P.; Evans, J. R. G.; Thompson, I.; Cook, R. J.; Robinson, P. J. Eur. Ceram. Soc. 2008, 28, 159167.

[721]Cardoso, G. B. C.; Ramos, S. L. F.; Rodas, A. C. D.; Higa, O. Z.; Zavaglia, C. A. C.; Arruda, A. C. F. J. Mater. Sci. 2010, 45, 4990-4993.

[722]Zhang, H.; Zhu, Q. Modern Phys. Lett. B 2009, 23, 3967-3976.

[723]Ribeiro, C. C.; Barrias, C. C.; Barbosa, M. A. J. Mater. Sci. Mater. Med. 2006, 17, 455-463.

[724]Ribeiro, C. C.; Barrias, C. C.; Barbosa, M. A. Biomaterials 2004, $25,4363-4373$.

[725]Zhou, W. Y.; Wang, M.; Cheung, W. L.; Guo, B. C.; Jia, D. M. J. Mater. Sci. Mater. Med. 2008, 19, 103-110.

[726] Kim, H. W.; Gu, H. J.; Lee, H. H. Tissue Eng. 2007, 13, $965-$ 973.

[727] Kawai, T.; Sekikawa, H.; Unuma, H. J. Ceram. Soc. Jpn. 2009, 117, 340-343.

[728]Descamps, M.; Hornez, J. C.; Leriche, A. J. Eur. Ceram. Soc. 2009, 29, 369-375.

[729]Cho, J. S.; Jung, D. S.; Han, J. M.; Kang, Y. C. J. Ceram. Process. Res. 2008, 9, 348-352.

[730] Kimura, I.; Honma, T.; Riman, R. E. J. Ceram. Soc. Jpn. 2007, 115, 888-893.

[731] Yao, A.; Ai, F.; Liu, X.; Wang, D.; Huang, W.; Xu, W. Mater. Res. Bull. 2010, 45, 25-28.

[732] Jiang, D.; Chen, M.; Li, D.; Zhu, J.; Lü, X.; Xie, J. Mater. Lett. 2009, 63, 2639-2642.

[733]Lim, J. H.; Park, J. H.; Park, E. K.; Kim, H. J.; Park, I. K.; Shin, H. Y.; Shin, H. I. Key Eng. Mater. 2008, 361-363, 119-122.

[734]Cho, J. S.; Ko, Y. N.; Koo, H. Y.; Kang, Y. C. J. Mater. Sci. Mater. Med. 2010, 21, 1143-1149.
[735]Ye, F.; Guo, H.; Zhang, H.; He, X. Acta Biomater. 2010, 6, 2212-2218.

[736]He, W.; Tao, J.; Pan, H.; Xu, R.; Tang, R. Chem. Lett. 2010, 39, 674-675.

[737]Itatani, K.; Tsugawa, T.; Umeda, T.; Musha, Y.; Davies, I. J.; Koda, S. J. Ceram. Soc. Jpn. 2010, 118, 462-466.

[738] Kamitakahara, M.; Murakami, S.; Takahashi, H.; Watanabe, N.; Ioku, K. Chem. Lett. 2010, 39, 854-855.

[739]Chandanshive, B.; Dyondi, D.; Ajgaonkar, V. R.; Banerjee, R.; Khushalani, D. J. Mater. Chem. 2010, 20, 6923-6928.

[740] Kim, M. K.; Kim, J. J.; Shin, U. S.; Kim, H. W. Mater. Lett. 2010, 64, 2655-2658.

[741] Simon, J. L.; Michna, S.; Lewis, J. A.; Rekow, E. D.; Thompson, V. P.; Smay, J. E.; Yampolsky, A.; Parsons, J. R.; Ricci, J. L. J. Biomed. Mater. Res. A 2007, 83A, 747-758.

[742]Chu, T. M.; Orton, D. G.; Hollister, S. J.; Feinberg, S. E.; Halloran, J. W. Biomaterials 2002, 23, 1283-1293.

[743] Yoshikawa, H.; Myoui, A. J. Artif. Organs 2005, 8, 131-136.

[744]Detsch, R.; Uhl, F.; Deisinger, U.; Ziegler, G. Key Eng. Mater. 2008, 361-363, 1181-1184.

[745]Min, S. H.; Jin, H. H.; Park, H. Y.; Park, I. M.; Park, H. C.; Yoon, S. Y. Mater. Sci. Forum 2006, 510-511, 754-757.

[746]Deville, S.; Saiz, E.; Nalla, R. K.; Tomsia, A. P. Adv. Sci. Technol. 2006, 49, 148-152.

[747]Buckley, C. T.; O'Kelly, K. U. J. Biomed. Mater. Res. B (Appl. Biomater.) 2010, 93B, 459-467.

[748] Yang, W.; Zhou, D.; Yin, G.; Chen, H. J. Chinese Ceram. Soc. 2004, 32, 1143-1149.

[749] Ramay, H. R. R.; Zhang, M. Biomaterials 2004, 25, 5171-5180.

[750] Yuan, H.; van Blitterswijk, C. A.; de Groot, K.; de Bruijn, J. D. Tissue Eng. 2006, 12, 1607-1615.

[751]Chen, G.; Li, W.; Zhao, B.; Sun, K. J. Am. Ceram. Soc. 2009, 92, 945-948.

[752] Guo, D.; Xu, K.; Han, Y. J. Biomed. Mater. Res. A 2009, 88A, 43-52.

[753]Furuichi, K.; Oaki, Y.; Ichimiya, H.; Komotori, J.; Imai, H. Sci. Technol. Adv. Mater. 2006, 7, 219-225.

[754]Wei, J.; Jia, J.; Wu, F.; Wei, S.; Zhou, H.; Zhang, H.; Shin, J. W.; Liu, C. Biomaterials 2010, 31, 1260-1269.

[755]Gbureck, U.; Grolms, O.; Barralet, J. E.; Grover, L. M.; Thull, R. Biomaterials 2003, 24, 4123-4131.

[756] Gbureck, U.; Barralet, J. E.; Hofmann, M.; Thull, R. J. Am. Ceram. Soc. 2004, 87, 311-313.

[757]Bohner, M.; Luginbühl, R.; Reber, C.; Doebelin, N.; Baroud, G.; Conforto, E. Acta Biomater. 2009, 5, 3524-3535.

[758]Hagio, T.; Tanase, T.; Akiyama, J.; Iwai, K.; Asai, S. J. Ceram. Soc. Jpn. 2008, 116, 79-82.

[759]Hench, L. L.; Polak, J. M. Science 2002, 295, 1014-1017.

[760]Blawas, A. S.; Reichert, W. M. Biomaterials 1998, 19, 595-609.

[761] Kasai, T.; Sato, K.; Kanematsu, Y.; Shikimori, M.; Kanematsu, N.; Doi, Y. J. Craniofac. Surg. 2010, 21, 473-478. 
[762] Wang, L.; Fan, H.; Zhang, Z. Y.; Lou, A. J.; Pei, G. X.; Jiang, S.; Mu, T. W.; Qin, J. J.; Chen, S. Y.; Jin, D. Biomaterials 2010, 31, 9452-9461.

[763] Sánchez-Salcedo, S.; Izquierdo-Barba, I.; Arcos, D.; Vallet-Regí, M. Tissue Eng. 2006, 12, 279-290.

[764] Meganck, J. A.; Baumann, M. J.; Case, E. D.; McCabe, L. R.; Allar, J. N. J. Biomed. Mater. Res. A 2005, 72A, 115-126.

[765]Case, E. D.; Smith, I. O.; Baumann, M. J. Mater. Sci. Eng. A 2005, 390, 246-254.

[766] Sibilla, P.; Sereni, A.; Aguiari, G.; Banzi, M.; Manzati, E.; Mischiati, C.; Trombelli, L.; del Senno, L. J. Dent. Res. 2006, 85, 354-358.

[767] Verron, E.; Bouler, J. M. Key Eng. Mater. 2010, 441, 181-201.

[768] Ono, I.; Ohura, T.; Murata, M.; Yamaguchi, H.; Ohnuma, Y.; Kuboki, Y. Plast. Reconstr. Surg. 1992, 90, 870-879.

[769] Ono, I.; Yamashita, T.; Jin, H. Y.; Ito, Y.; Hamada, H.; Akasaka, Y.; Nakasu, M.; Ogawa, T.; Jimbow, K. Biomaterials 2004, 25, 4709-4718.

[770] Sawyer, A. A.; Hennessy, K. M.; Bellis, S. L. Biomaterials 2007, 28, 383-392.

[771] Mastrogiacomo, M.; Muraglia, A.; Komlev, V.; Peyrin, F.; Rustichelli, F.; Crovace, A.; Cancedda, R. Orthod. Craniofac. Res. 2005, 8, 277-284.

[772] Schek, R. M.; Taboas, J. M.; Hollister, S. J.; Krebsbach, P. H. Orthod. Craniofac. Res. 2005, 8, 313-319.

[773] Krylova, E. A.; Ivanov, A. A.; Krylov, S. E.; Plashchina, I. G.; Grigorjan, A. S.; Goldstein, D. V.; Pulin, A. A.; Fatkhudinov, T. H. Minerva Biotecnol. 2006, 18, 17-22.
[774]Nishikawa, M.; Myoui, A.; Ohgushi, H.; Ikeuchi, M.; Tamai, N.; Yoshikawa, H. Cell Transplant. 2004, 3, 367-376.

[775]Quarto, R.; Mastrogiacomo, M.; Cancedda, R.; Kutepov, S. M.; Mukhachev, V; Lavroukov, A.; Kon, E.; Marcacci, M. N. Engl. J. Med. 2001, 344, 385-386.

[776] Vacanti, C. A.; Bonassar, L. J.; Vacanti, M. P.; Shufflebarger, J. N. Engl. J. Med. 2001, 344, 1511-1514.

[777] Morishita, T.; Honoki, K.; Ohgushi, H.; Kotobuki, N.; Matsushima, A.; Takakura, Y. Artif. Organs 2006, 30, 115-118.

[778]Eniwumide, J. O.; Yuan, H.; Cartmell, S. H.; Meijer, G. J.; de Bruijn, J. D. Eur. Cell Mater. 2007, 14, 30-39.

[779]Zuolin, J.; Hong, Q.; Jiali, T. Med. Hypotheses 2010, 75, 669670.

[780]Hench, L. L.; Wilson, J. Science 1984, 226, 630-636.

[781] Navarro, M.; Michiardi, A.; Castano O.; Planell, J. A. J. R. Soc. Interface 2008, 5, 1137-1158.

[782] Anderson, J. M. J. Mater. Sci. Mater. Med. 2006, 17, 1025-1028.

[783] Chevalier, J.; Gremillard, L. J. Eur. Ceram. Soc. 2009, 29, 12451255.

[784]Hartgerink, J. D.; Beniash, E.; Stupp, S. I. Science 2001, 294, 1684-1688.

[785]Zhou, K.; Zhang, Y.; Zhang, D.; Zhang, X.; Li, Z.; Liu, G.; Button, T. W. Scripta Mater. 2011, 64, 426-429.

[786]Rapoport, A.; Borovikova, D.; Kokina, A.; Patmalnieks, A.; Polyak, N.; Pavlovska, I.; Mezinskis, G.; Dekhtyar, Y. Immobilisation of yeast cells on the surface of hydroxyapatite ceramics. Process Biochem. 2011, 46, 665-670.

[787] Xuebin, Z.; Yunfei, D.; Songlin, W.; Jie, X.; Yi, F. Ceramics Silikaty 2010, 54, 248-252. 